Volumina Jurassica, 2020, XVIII (2): 121-160

DOI: $10.7306 /$ VJ.18.7

\title{
The proposal of a GSSP for the Berriasian Stage (Cretaceous System): Part 2
}

\author{
William A.P. WIMBLEDON ${ }^{1}$, Daniela REHÁKOVÁ ${ }^{2}$, Andrea SVOBODOVÁ ${ }^{3}$, Tiiu ELBRA ${ }^{3}$, Petr SCHNABL $^{3}$, \\ Petr PRUNER ${ }^{3}$, Krýstina ŠIFNEROVÁ ${ }^{3}$, Šimon KDÝR ${ }^{3}$, Camille FRAU $^{4}$, Johann SCHNYDER $^{5}$, \\ Bruno GALBRUN ${ }^{5}$, Lucie VAŇKOVÁ ${ }^{6}$, Oksana DZYUBA $^{7}$, Philip COPESTAKE ${ }^{8}$, Christopher O. HUNT ${ }^{9}$, \\ Alberto RICCARDI ${ }^{10}$, Terry P. POULTON ${ }^{11}$, Luc G. BULOT ${ }^{12,13}$, Luis DE LENA ${ }^{14}$
}

Key words: Cretaceous, Berriasian Stage, GSSP, biostratigraphy, magnetostratigraphy, Vocontian Basin.

\begin{abstract}
In part 1 of this work we discussed the possibilities for the selection of a GSSP for the Berriasian Stage of the Cretaceous System, based on prevailing practical methods for correlation in that $\mathrm{J} / \mathrm{K}$ interval, traditional usage and the consensus over the best boundary markers that had developed in the last forty years. This consensus has developed further, based on the results of multidisciplinary studies on numerous sites over the last decade. Here in Part 2 we give an account of the application of those results by the Berriasian Working Group (ISCS), and present the stratigraphic evidence that justifies the selection of the locality of Tré Maroua (Hautes-Alpes, SE France) as the proposed GSSP. We describe a 45 m-thick section in the Calcaires Blancs vocontiens - that part of the formation covering the calpionellid Chitinoidella, Remanei. Intermedia, Colomi, Alpina, Ferasini, Elliptica and Simplex biozones. The stratigraphic data collected here has been compiled as part of a wider comparative study of complementary Vocontian Basin sites (with localities at Charens, St Bertrand, Belvedere and Le Chouet). Evidence from Tré Maroua thus sits in this substantial regional biostratigraphic and magnetostratigraphic con-
\end{abstract}

\footnotetext{
${ }^{1}$ School of Earth Sciences, University of Bristol, Wills Memorial Building, Queens Road, Bristol BS8 1RJ, United Kingdom; mishenka1@yahoo.co.uk.

${ }^{2}$ Department of Geology and Paleontology, Faculty of Natural Sciences, Comenius University, Ilkovičova 6, 84215 Bratislava, Slovakia; rehakova@fns.uniba.sk.

${ }^{3}$ The Czech Academy of Sciences, Institute of Geology, Rozvojová 269, 16500 Prague, Czech Republic; asvobodova@gli.cas.cz, elbra@gli.cas.cz, schnabl@gli.cas.cz,pruner@gli.cas.cz; cizkovak@gli.cas.cz,kdyr@gli.cas.cz.

${ }^{4}$ Groupement d'Intérêt Paléontologique, Science et Exposition, 60 bd Georges Richard, 83000 Toulon, France; camille_frau@hotmail.fr.

${ }^{5}$ Sorbonne Université, UPMC Université Paris 06, CNRS, Institut des Sciences de la Terre Paris (ISTeP), 75005 Paris, France; johann.schnyder@sorbonne-universite.fr, bruno.galbrun@sorbonne-universite.fr.

${ }^{6}$ Institute of Geology and Palaeontology, Faculty of Science, Charles University, Albertov 6, Prague 2, 128 43, Czech Republic; vankova.luc@seznam.cz.

${ }^{7}$ Trofimuk Institute of Petroleum Geology and Geophysics, Siberian Branch of RAS, Acad. Koptyug av. 3, Novosibirsk 630090, Russia; DzyubaOS@ipgg.sbras.ru.

${ }^{8}$ Merlin Energy Resources Ltd., New Street, Ledbury, Herefordshire, HR8 2EJ, United Kingdom; Phil_Copestake@merlinenergy.co.uk.

${ }^{9}$ School of Biological \& Environmental Sciences, Liverpool John Moores University, Byrom St., Liverpool L3 3AH, United Kingdom; C.O.Hunt@ljmu.ac.uk.

10 CONICET - Museo de La Plata, Universidad Nacional de La Plata, Paseo del Bosque s/n, 1900 La Plata, Argentina; riccardi@fcnym.unlp.edu.ar.

${ }^{11}$ Geological Survey of Canada, Calgary, Alberta, T2L 2Al, Canada; terry.poulton@canada.ca.

${ }^{12}$ Aix-Marseille Université, CNRS, IRD, INRAE, Collège de France, Cerege, Site Saint-Charles, Case 67, 3, Place Victor Hugo, 13331 Marseille Cedex 3 , France; luc.bulot@manchester.ac.uk.

13 NARG, School of Earth, Atmospheric and Environmental Sciences, University of Manchester, Williamson Building, Oxford Road, Manchester M13 9PL, United Kingdom.

${ }^{14}$ Department of Earth Sciences, University of Geneva, Geneva, 1205, Switzerland; lena.luis@gmail.com.
} 
text. For the purposes of the GSSP definition, here we particularly concentrate on the unbroken sequence and biotic markers in the interval immediately below the boundary, the Colomi Subzone (covering circa 675,000 years), and immediately above, the Alpina Subzone (covering circa 725,000 years). Particularly significant fossil datums identified in the Tré Maroua profile are the primary basal Berriasian marker, the base of the Alpina Subzone (a widespread event marked by dominance of small Calpionella alpina, with rare Crassicollaria parvula and Tintinopsella carpathica): the base of the Berriasian Stage is placed at the base of bed 14, which coincides with the base of the Alpina Subzone. Secondary markers bracketing the base of the Calpionella Zone are the FOs of the calcareous nannofossil species Nannoconus wintereri, close below the boundary, and the FO of Nannoconus steinmannii minor, close above. The Tithonian/Berriasian boundary level occurs within M19n.2n, in common with many documented sites, and is just below the distinctive reversed magnetic subzone M19n.1r (the so-called Brodno reversal). We present data which is congruent with magnetostratigraphic and biostratigraphic data from other key localities in France and in wider regions (Le Chouet, Saint Bertrand, Puerto Escaño, Rio Argos, Bosso, Brodno, Kurovice, Theodosia...), and thus the characteristics and datums identified at Tré Maroua are key for correlation and, in general, they typify the $\mathrm{J} / \mathrm{K}$ boundary interval in Tethys and connected seas.

\section{INTRODUCTION}

Part 1 of this work showed how, over the generations, correlations in the late Tithonian and early Berriasian had been hampered by regional biotic endemism, how attempts to expand the ammonite zonal scheme of Mediterranean Tethys (Jacobi and Occitanica zones) into other regions had had limited success, and how possibilities for correlation in the $\mathrm{J} / \mathrm{K}$ boundary interval had been revolutionised by the application of magnetostratigraphy and a suite of biostratigraphically consistent microfossil markers (calpionellids, calcareous nannofossils, and dinocysts).

In the last ten years the work of the Berriasian group, focussed solely on the search for a GSSP, has greatly expanded our knowledge and the data we can bring to bear on the age-old $\mathrm{J} / \mathrm{K}$ boundary problem, as the literature derived from the group, and a wider circle of comrades, bears witness (Guzhikov, Baraboshkin, 2008; Wimbledon, 2008, 2014, 2017; Boughdiri et al., 2009; Michalík et al., 2009, 2016; Pessagno et al., 2009; Pszczółkowski, 2009, 2013, 2016; Reháková et al., 2009, 2011; Rogov, Zakharov, 2009; Ben Abdesselam-Mahdaoui et al., 2010, 2011; Casellato, 2010; Channell et al., 2010; Dzyuba, 2010, 2012, 2013; Grabowski, 2010; Grabowski et al., 2010a, b, 2014, 2016, 2019; Lukeneder et al., 2010; Pruner et al., 2010; Rogov, 2010; Harding et al., 2011; Kietzmann et al., 2011, 2018a, b; Michalík, Reháková, 2011; Pestchevitskaya et al., 2011; Sallouhi et al., 2011; Wimbledon et al., 2011, 2013, 2016, 2017, 2020a; Žák et al., 2011; Arkad'ev et al., 2012, 2015; Benzaggagh et al., 2012, 2015; Cecca et al., 2012; Guzhikov et al., 2012, 2016; Petrova et al., 2012, 2019; Vennari et al., 2012, 2014; Bragin et al., 2013; Dzyuba et al., 2013, 2015; Guzhikov, 2013; Lakova, Petrova, 2013; López-Martínez et al., 2013a-c, 2015a, b, 2017; Bulot et al., 2014; Platonov et al., 2014; Urman et al., 2014; Zakharov et al., 2014; Aguirre-Urreta et al., 2015, 2017, 2019; Baraboshkin et al. 2015; Frau et al., 2015, 2016a-c, 2020; Iglesia Llanos et al., 2015, 2017; Riccardi, 2015; Rogov et al., 2015; Sano et al., 2015; Satolli et al., 2015; Schnabl et al., 2015, 2019; Shurygin, Dzyuba, 2015; Bakhmutov et al., 2016, 2018; Hoedemaeker et al., 2016; Ivanova, Kietzmann, 2016, 2017; Price et al., 2016; Satolli, Turtu, 2016; Svobodová, Košták, 2016; Wohlwend et al., 2016; Celestino et al., 2017; Kietzmann, 2017; Kuznetsov et al., 2017; Lakova et al., 2017; Vašíček et al., 2017; Elbra et al., 2018a, b; Stoykova et al., 2018; Galloway et al., 2019; Haggart, Matsukawa, 2019; Kowal-Kasprzyk, Reháková, 2019; Lena et al., 2019; NøhrHansen et al., 2019; Reháková, Rozic, 2019; Svobodová et al., 2019; Vaňková et al., 2019; Barragán et al., 2020). It is upon this foundation that decisions over selection of a primary boundary marker and comparisons of rival GSSP contenders have been based.

Herein we present Part 2 of the proposal of a Global Boundary Stratotype Section and Point for the Berriasian Stage (Cretaceous System), made by the Berriasian Working Group to the International Subcommission on Cretaceous Stratigraphy (ICS) on $1^{\text {st }}$ December 2019.

As laid out in Part 1, the site proposed, Tré Maroua, shows a range of characteristics and markers which typify the $\mathrm{J} / \mathrm{K}$ boundary interval. Its features are consistent with those recorded in other Vocontian Basin sections and numerous other localities in wider regions, the literature for which (on calpionellids, calcareous nannofossils, ammonites, calcareous dinoflagellates, magnetostratigraphy etc.) has been surveyed and discussed in the now published Part 1 (Wimbledon et al., 2020b).

Tré Maroua is one of a group of Tithonian-Berriasian sections in the central to eastern Vocontian Basin, in the departments of Drôme and Hautes-Alpes, that have been studied in detail in recent years and considered as potential GSSPs for the Berriasian Stage (Fig. 1). This proposal is thus not of a site that sits in isolation, as is the case with many selected GSSPs: it is one of several adjacent sites that show complementary features, and variations in lithology and biota, and differences in biozonal and bed thickness and breccia development. The overall 'ideal' pattern can be discerned by comparing the sites in the group (Wimbledon 


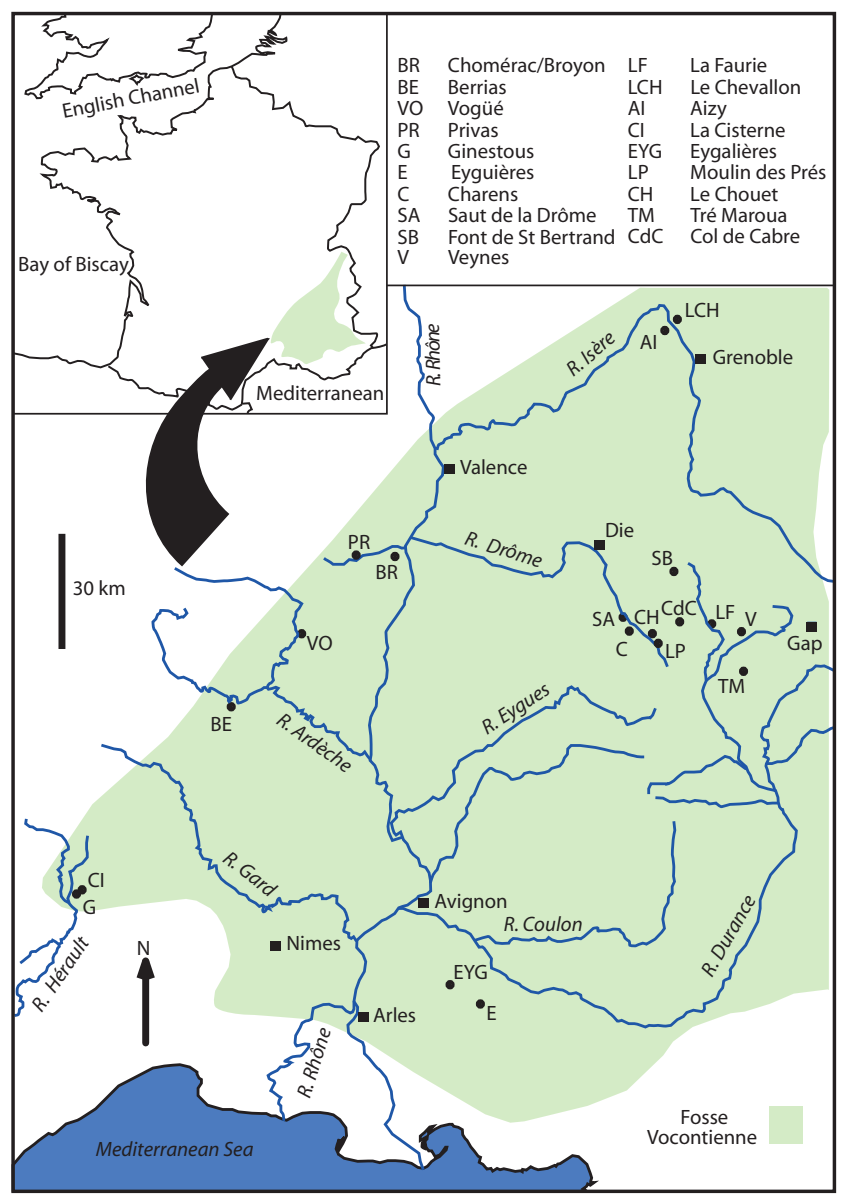

Fig. 1. Vocontian Basin J/K locality map

et al., 2013; Bulot et al., 2014; Frau et al., 2015, 2016a-c; Elbra et al., 2018a; Wimbledon et al., 2020a). The stratigraphic context, comparisons, and reasoning behind the selection of the chosen locality has been published in Part 1 of this work. Here we describe Tré Maroua as the best exemplar for the immediate boundary interval - the Colomi-Alpina calpionellid subzones.

\section{THE PROPOSED GSSP - TRÉ MAROUA}

\subsection{GEOGRAPHICAL AND GEOLOGICAL SETTING}

Tré Maroua is located on forested mountain slopes, one kilometre SSE of the village of Le Saix (Hautes-Alpes, France), about $20 \mathrm{~km}$ southwest of the town of Gap. Geologically, it lies in the syncline of the Ajour Mountain (Figs 2-4).

The main outcrops at Tré Maroua form a SE-facing strike section, comprising a lower vertical cliff and an upper slope above the gorge of the Torrent de Tré Maroua. On the NE-facing side of the hill a continuation of the exposures occurs in a dip section at the mouth of the Tré Maroua, and this succession can be traced up-dip to the NW, along the left bank of the Torrent de Maraize. We have studied the lower stream-side section at the mouth of the Torrent de Tré Maroua, and our second studied profile shows a larger transect from the edge of the main cliff in the gorge of Tré Maroua and thence across the hillside above.

As can be seen from the frontispiece and the photo with markers drawn on, there is almost one hundred percent exposure at Tré Maroua.

The proposed GSSP and related sites, documented in parallel, lie in the eastern central part of the Vocontian Basin of SE France (Fig. 1). All the recently documented localities are thus some considerable distance from the Berriasian type area of Ardèche, on the right bank of the Rhône, and classical sites such as Berrias and Chomérac, which lie about $100 \mathrm{~km}$ to the west. There, Berrias, the historical stratotype, was the first site studied in detail by the Working Group. $\mathrm{J} / \mathrm{K}$ sequences in Ardèche and Gard are frequently severely affected by hiatuses, erosional events and breccia development, and macrofossils had often had to be collected ex situ, and even from field brash, and the Berrias profile itself has its lowest bed within the calpionellid Alpina Subzone (neither the base of this zone, nor of the ammonite Jacobi Subzone, is exposed). The detailed study of more eastern sites in the basin, between Die and Veynes (in the departments of Drôme and Hautes-Alpes), was driven by a need to investigate sequences without such deficiencies in the boundary interval: that is, fossiliferous, well-exposed and continuous Tithonian-Berriasian profiles, in the ColomiAlpina (calpionellid) and Andreaei-Jacobi (ammonite) biozones. This group of complementary sites comprises cliffs, hillside outcrops and road cuttings perched on the side of precipitous valley slopes of the upper reaches of the rivers Drôme and Durance. After reconnaissance of the area, some earlier-documented localities were located and re-studied, between 2009 and 2018, though others were found to be too degraded and/or badly overgrown (La Faurie) or not wellenough developed or accessible (Saut de la Drôme) in the critical interval.

Comparisons are made in this document with other sites in the Vocontian Basin (in Drôme and Hautes-Alpes): Tré Maroua and they have been documented as a group, with similar or the same features in their lithologies, facies, palaeontology and biostratigraphy (Wimbledon et al., 2020a). They were assessed collectively, so as to reveal the best candidate amongst them to be a putative GSSP. Studies focussed firstly on the Le Chouet road cuttings, and then Saint Bertrand to show higher units in the Berriasian, and next on Charens to provide lower units in the Tithonian. Later, fur- 


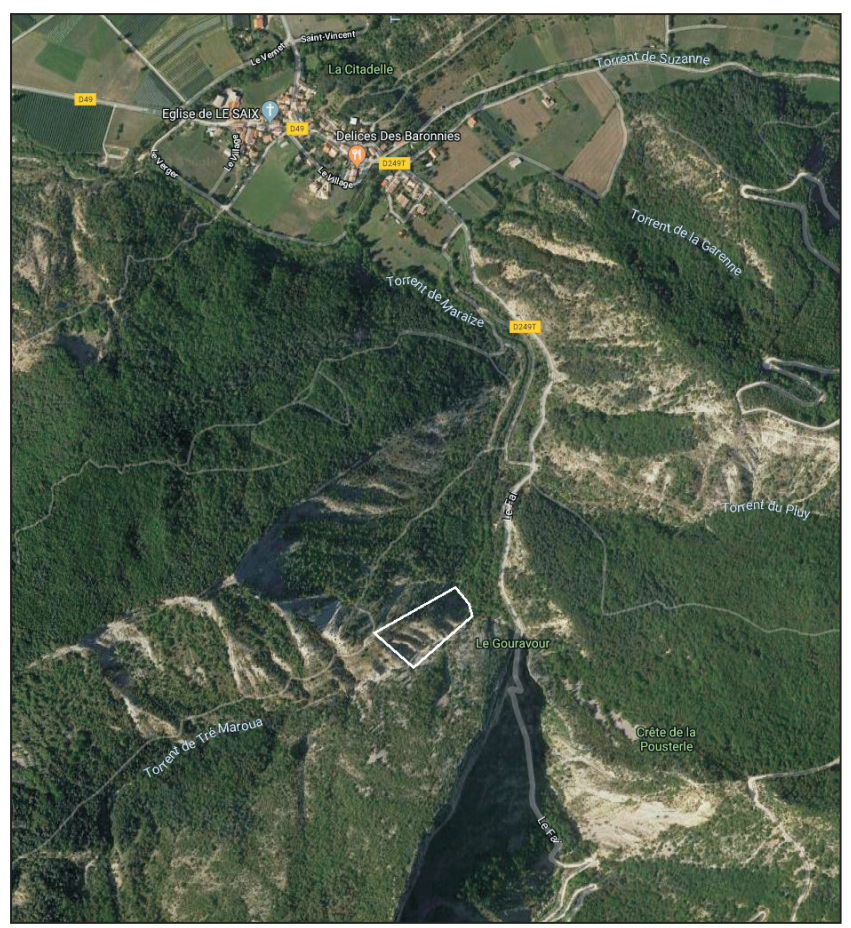

Fig. 2. Aerial photograph of the Le Saix area (Hautes-Alpes)

The studied Tré Maroua hillside outcrops fall within the white rectangle (Google Earth screenshot)

ther boundary interval sections with lesser breccia developments were documented at Haute Beaume (Belvedere) and Tré Maroua. As with the other studied localities, Tré Maroua is situated on geological sheet 868 , Luc en Diois $(1: 50,000)$, published by the national Bureau de Recherches Géologiques et Minières.

There is a voluminous literature on the Vocontian Basin $\mathrm{J} / \mathrm{K}$ interval, but publications on the biostratigraphy of the five studied localities are relatively few: most are cited in the BWG publications listed below. Notable in earlier publications is Le Hégarat's (1973) classic opus, which records ammonites (at Le Chouet, Tré Maroua and, more extensively, at St Bertrand (called by him Les Combes)) in his fundamental account of Vocontian Basin biostratigraphy. This followed Remane's (1964) work on calpionellid zones and breccia developments at Haute Beaume, Charens and Le Chouet. Since 2013, the Berriasian WG has discussed in print integrated bio- and magnetostratigraphic data, ammonite and calpionellid faunas and calcareous nannofossils (Wimbledon et al., 2013; Bulot et al., 2014; Frau et al., 2015, 2016a-c; Elbra et al., 2018a).

The Working Group has already presented a synthesis of magnetostratigraphic and biostratigraphic results based on a detailed study of Tré Maroua and the four other localities

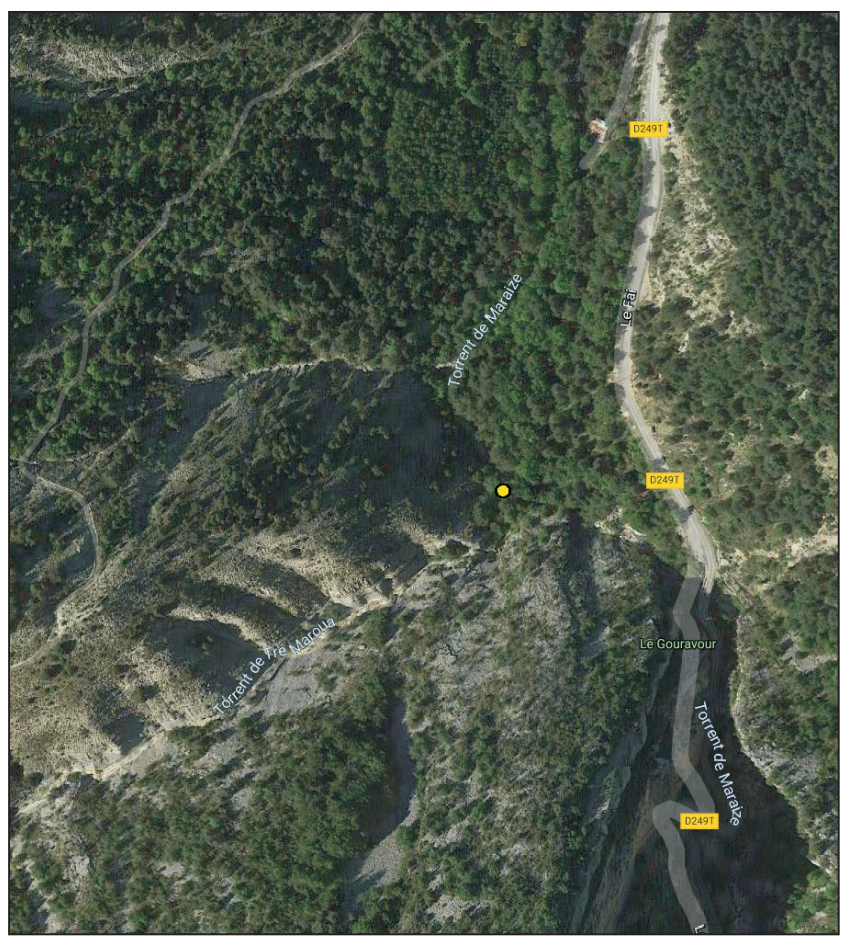

Fig. 3. Aerial photograph of the vicinity of Tré Maroua

The yellow dot marks the position of the GSSP, concealed in riverside woodland (Google Earth screenshot)

(Wimbledon et al., 2020a), plus initial data on carbon isotopes from Le Chouet. The locations of the five Vocontian Basin localities documented and compared by the Berriasian WG are as follows: the Tré Maroua torrent and hillside section (base of the profile is at $44^{\circ} 28^{\prime} 00^{\prime \prime} \mathrm{N}, 05^{\circ} 49^{\prime} 40^{\prime \prime} \mathrm{E}$ ), with an average dip of $39^{\circ}$ to $40^{\circ}$, the Le Chouet road section in the lower Fournet Ravine, the Charens gorge road (D93) cutting, the Saint Bertrand hillside and gorge profiles, off the D539, and the Belvedere road cutting near Haute Beaume. The cumulative interval studied spans the highest Lower Tithonian to Upper Berriasian: that is, pre-Chitinoidella Zone strata (Semiradiata calcareous dinocyst zone sensu Reháková 2000a, b) to beds in the Simplex Subzone (Calpionellopsis Zone), a magnetostratigraphic interval of M20r-M17n.

Regionally, the profile of Tré Maroua makes up part of the succession of the Vocontian Basin (or Trough), which comprises deeper-water hemipelagic sediments of JurassicCretaceous age, termed sometimes the Subalpine Basin (Baudrimont, Dubois, 1977, Debrand-Passard et al., 1984), assigned to the Calcaires Blancs vocontiens. The geological setting of the basin has been described many times: it was circa $250 \mathrm{~km}$ across, E-W, narrowing north-eastwards towards the Jura (Fig. 1). 


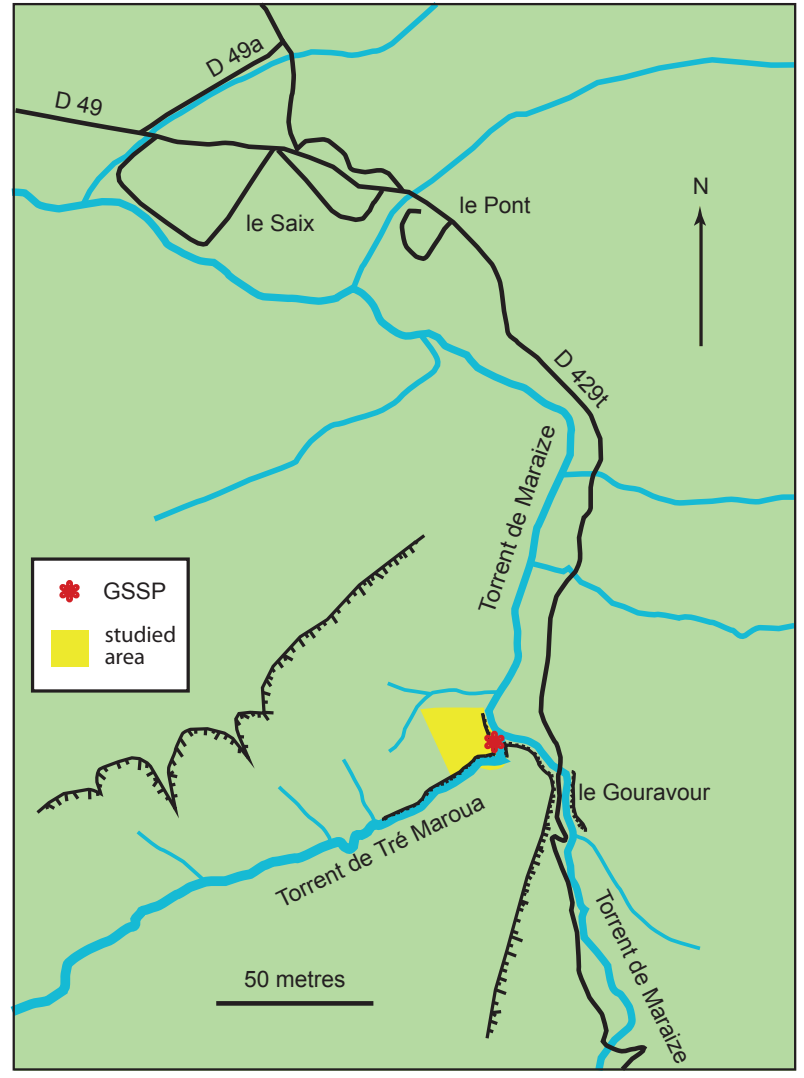

Fig. 4. Topographical map of the vicinity of Tré Maroua and Le Saix

The basin deepened through the early Cretaceous, with sedimentation delimited by the massifs of the Cévennes to the west and Les Maures in the south, whereas eastwards the basin was open to oceanic Tethys. In some areas, particularly in the north, successions contain marginal marine and non-marine Purbeck facies (Détraz, Mojon, 1989). As well as these non-marine connections, there appear to have occurred periodic, but poorly documented, marine incursions north-westwards into the non-marine Anglo-French Purbeck basin.

"Breccias" are commonplace and a spectacular feature of Tithonian sections in the Drôme and Hautes-Alpes departments, and such lithologies persist into the Berriasian. Some are actually conglomerates (often with well-rounded clasts), and some comprise matrix-supported limestone clasts. Some represent catastrophic large-scale downcutting events, whereas others are evidence of short-lived inputs of grainstones, microbreccia, or matrix supported small clasts, which had no observable affect on the normal micrite/biomicrite sedimentation. The debris was carried into the basin down what earlier accounts described as submarine canyons from the NW, and to a lesser extent from its southern margin. Pioneering work by Remane (1964) on carbonate sedimentation in the Vocontian Basin was followed by further key publications by Beaudoin $(1970,1977)$ and Joseph et al. (1988). Courjault et al. (2011) give an excellent account of 'breccia' lobes in the Tithonian. In the Colomi and Alpina subzones at Belvedere, St Bertrand and Tré Maroua breccias are largely absent. Though thin breccia injections and inputs of rare pebbles are present in all sections. Breccias are superbly and massively developed in the Tithonian of the Charens valley, and there they also make a reappearance in the Alpina Subzone, as at the top of the zone on the Le Chouet road (and in the Fournet Ravine). Such developments are shown, with clasts to scale, on the relevant figures herein. Of the localities studied, breccias at Tré Maroua are amongst the least developed, and, by comparison, they are minimally developed in the critical Colomi-Alpina zonal interval.

Two parts of the stratigraphic sequence exposed at Tré Maroua are chosen to be figured herein (Figs 5, 6). The first is a lower section at the mouth of the Torrent de Tré Maroua, immediately above where that tributary stream joins the main river (the Torrent de Maraize). Outcrop continues from there around a bend in the tributary and extends to the SW, following its gorge, along strike for hundreds of metres. Exposure along strike is continuous. The lower outcrop, a dip section comprising beds $1-28$, is shown in the right-hand column, B in Fig 5. Column A in the same figure depicts an upward extension of the sequence about $50 \mathrm{~m}$ to the SW, beds $1-34$, extending from the top of the lower cliff in the Tré Maroua gorge. The sequence continues thence across the hillside (shown in Fig. 6, beds 35-126), with higher beds typified by marl/limestone alternations. There is an overlap between the two recorded main profiles: bed 28 in the lower section equates along strike, to bed 6 at the base of the lower part of the upper section (see Fig. 5). In the account below, the prefix "TL" denotes samples from the lower section, and " $T$ " those from the upper profile.

A high-angle strike fault in the lower section (Fig. 5B) coincides with the base of bed 12, and causes its lower part to be repeated (logged as unit 11). The fault can be traced to the southwest in the exposure, to where it meets the stream course of Tré Maroua (Fig. 7). The fault plane is very obvious there in a small waterfall, where the top part of bed 10 is caught up in the fault. To the SW, on the right bank of the stream, the fault is absent. There, only circa $10 \mathrm{~m}$ from the GSSP section, the bedding is undisturbed, and beds 10 and 12 are fully developed, though without small clasts at the base of the latter (Fig. 7). Overall, bed thicknesses are consistent in the very short distance between the GSSP section and that on the right bank of the torrent. Calpionellid data for these auxiliary outcrops, additional to that already published (Wimbledon et al., 2020a), is described below. It can 


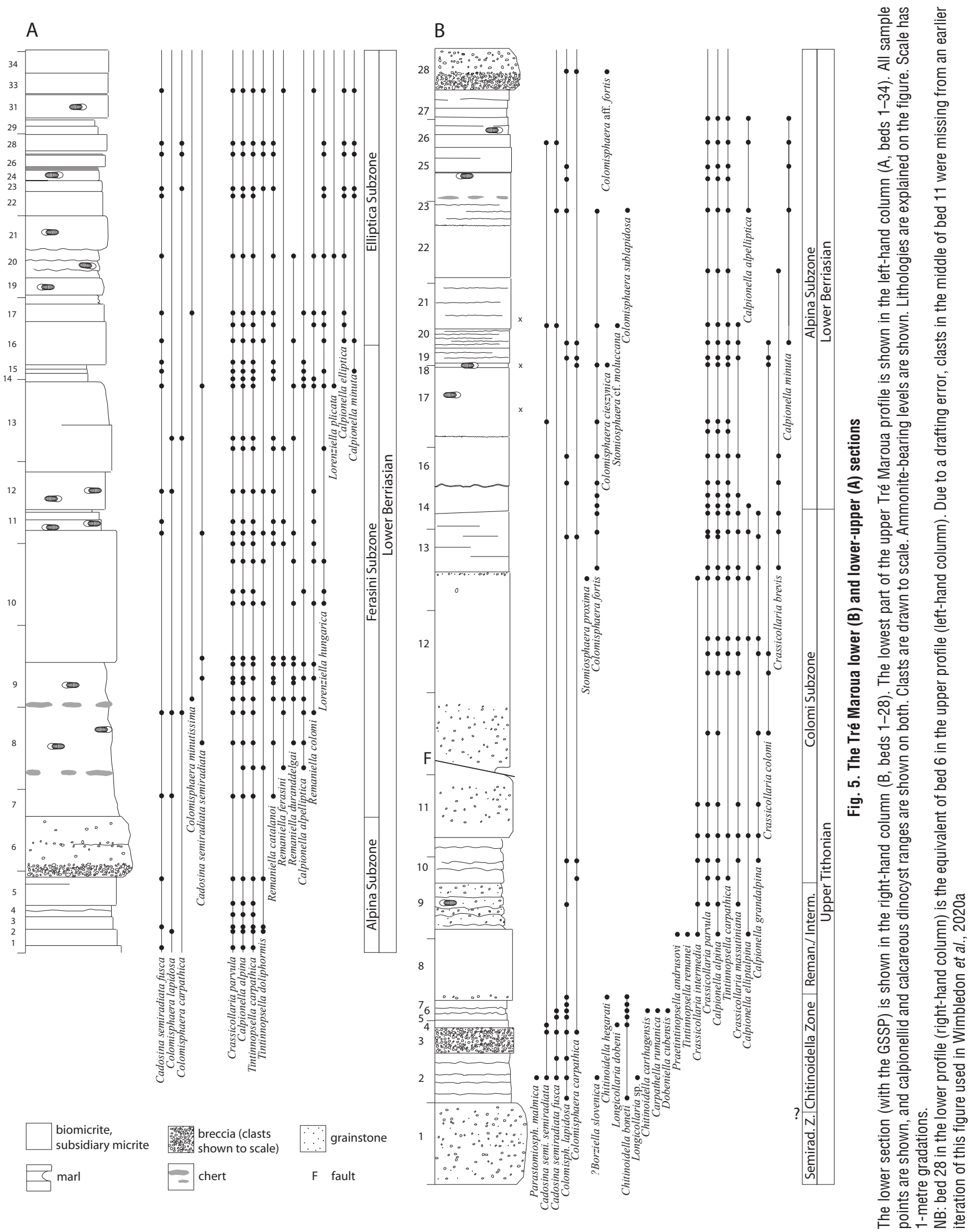




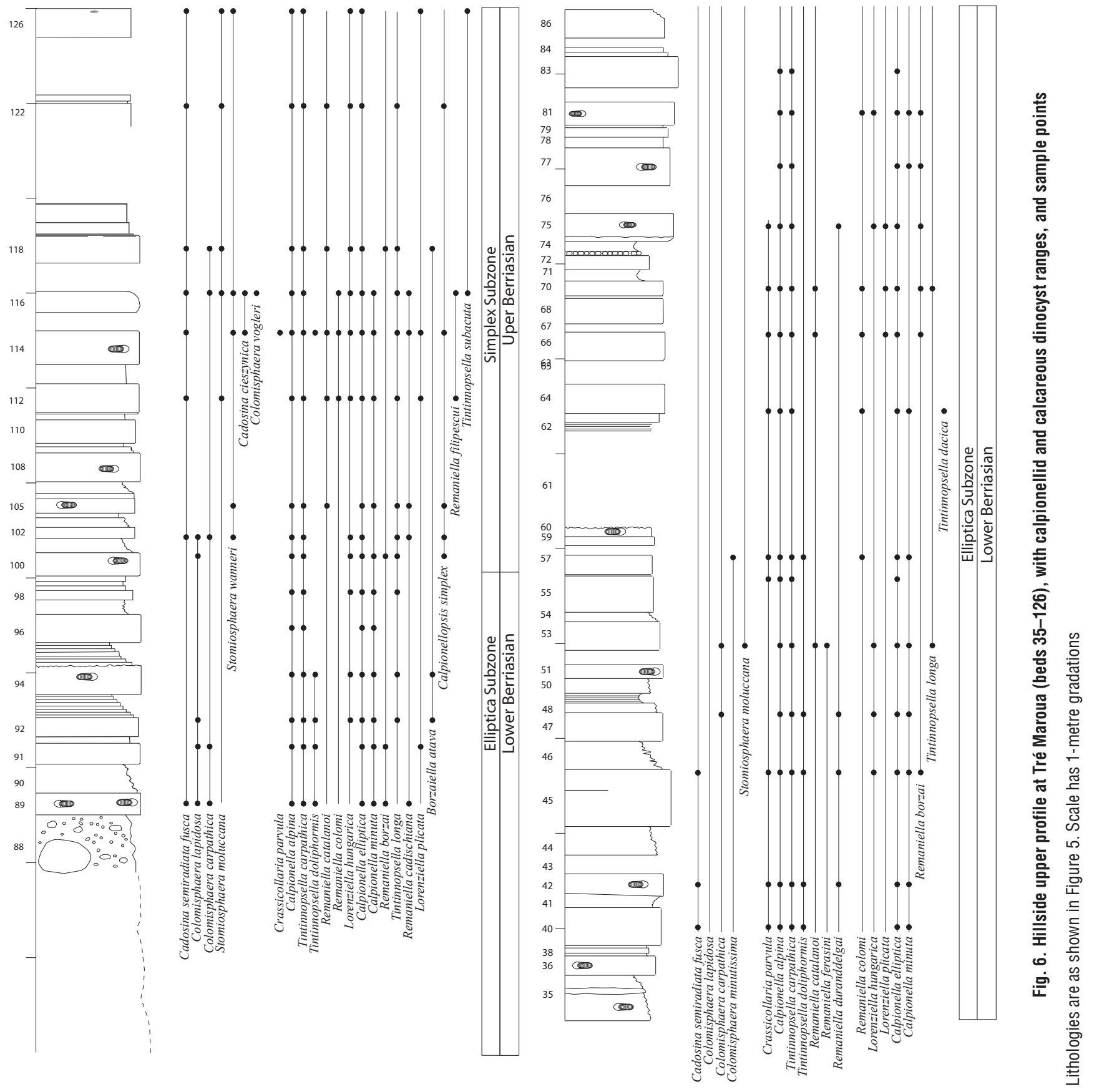




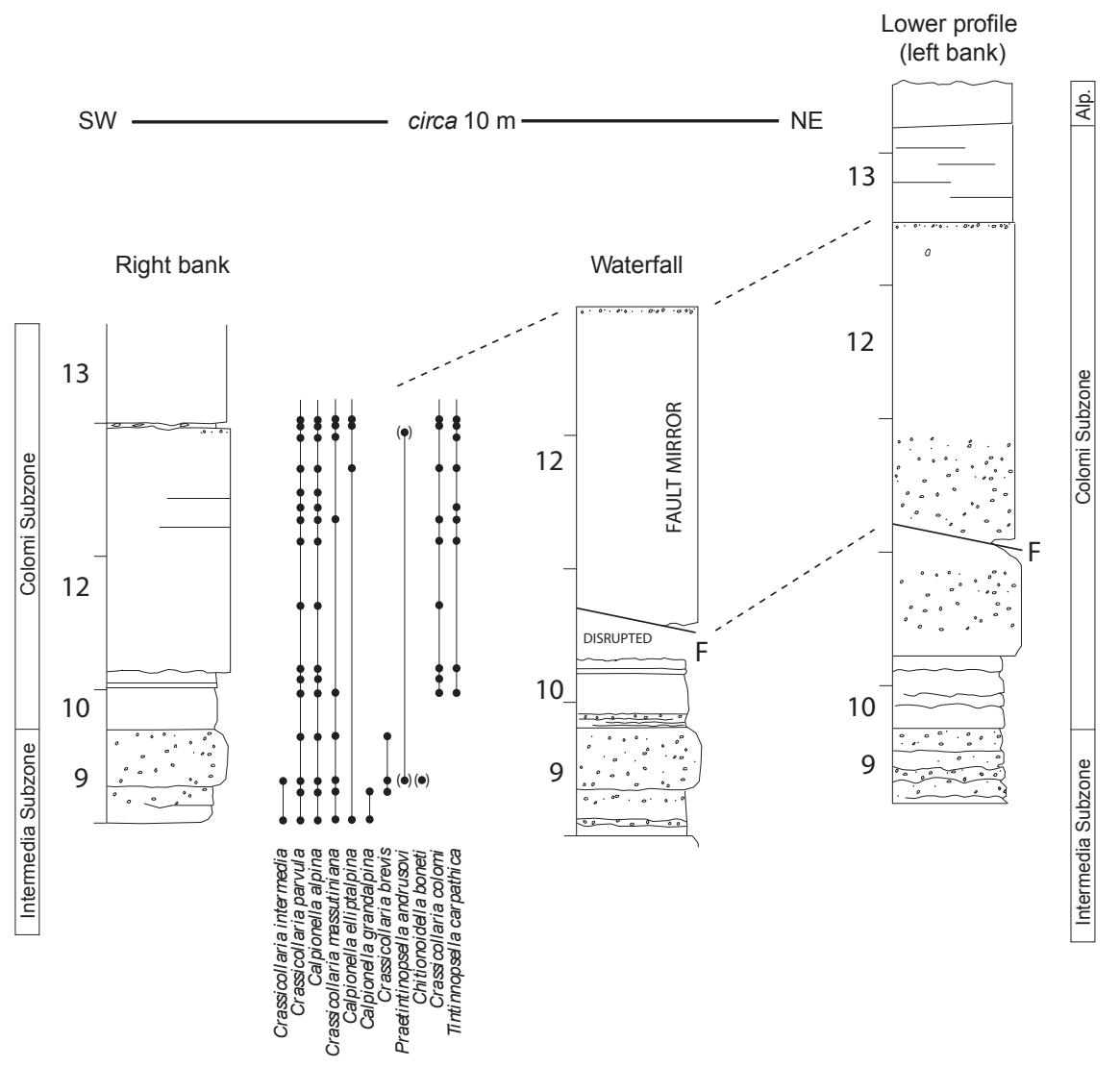

Fig. 7. Right-bank section compared with the lower Tré Maroua profile (Fig. 5B), with calpionellid distribution

Brackets denote derived taxa

be stated that the succession of calpionellid and nannofossil markers is normal in the Colomi and Alpina subzones, unaffected in any significant way by any reworking, hiatus or disruption, for instance by the input of thin microbreccias.

\subsection{LITHOSTRATIGRAPHY AND BIOSTRATIGRAPHY}

The Tré Maroua locality comprises extensive cliffs and steep hillside outcrops in the angle between the Torrent de Maraize and the narrow ravine of its tributary, the Torrent de Tré Maroua. Lithostratigraphically, these exposures and those at other studied local profiles show the Calcaires Blancs vocontiens (sensu Le Hégarat, 1973), a formation which straddles the Tithonian and Berriasian stages. The sequences seen in all the sections locally comprise well-bedded and massive micritic limestone units below and alternating micrites and marls above. Common and diverse ammonites, aptychi and rarer bivalves typify some beds through the ammonite zonal interval of Microcanthum, Andreaei, Jacobi and Occitanica.
Figures herein (Figs 5, 6), show lithostratigraphy combined with vertical ranges of calpionellid and calcareous dinocyst taxa and, separately. Figure 8 shows magnetostratigraphy and the first occurrences (FOs) of key calcareous nannofossil species. All calcareous nannofossils occurrences are shown in Figure 9. Logs of the profiles at Charens, Saint Bertrand, Belvedere and Le Chouet have previously been published for comparison (Wimbledon et al., 2020a); the micropalaeontological results from those sites and the biozonations derived therefrom are based on a study of almost seven hundred samples collected by the WG and used for thin sections and smear slide production.

The microfacies of the proposed GSSP section and complementary Vocontian sites have been published (Wimbledon et al., 2020a, fig. 2). The microfacies documented in those profiles may be assigned to categories SMF 2, SMF 3 and SMF 4 of Flügel $(2004,2010)$. Facies zones FZ 3 and FZ 4 indicate deposition in upper to mid slope environments. Details of the microfacies of samples taken in the lower Tré Maroua and accessory torrent section are given in an appendix below. 
B

$\mathbf{A}$

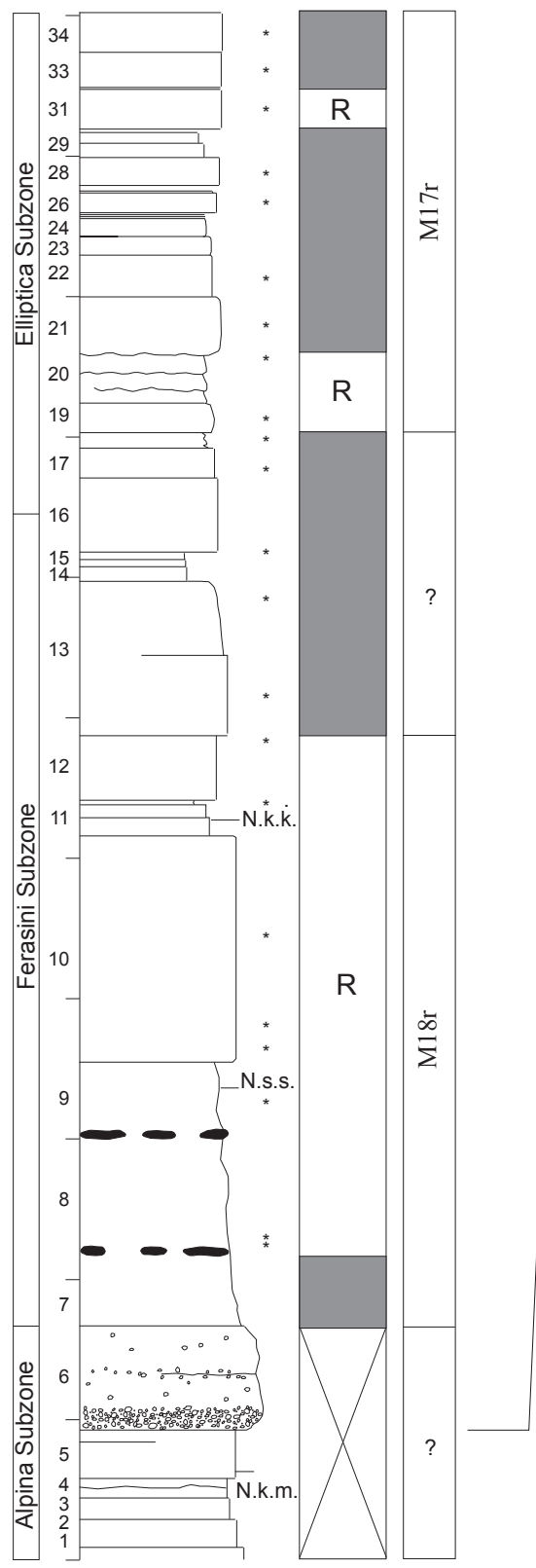

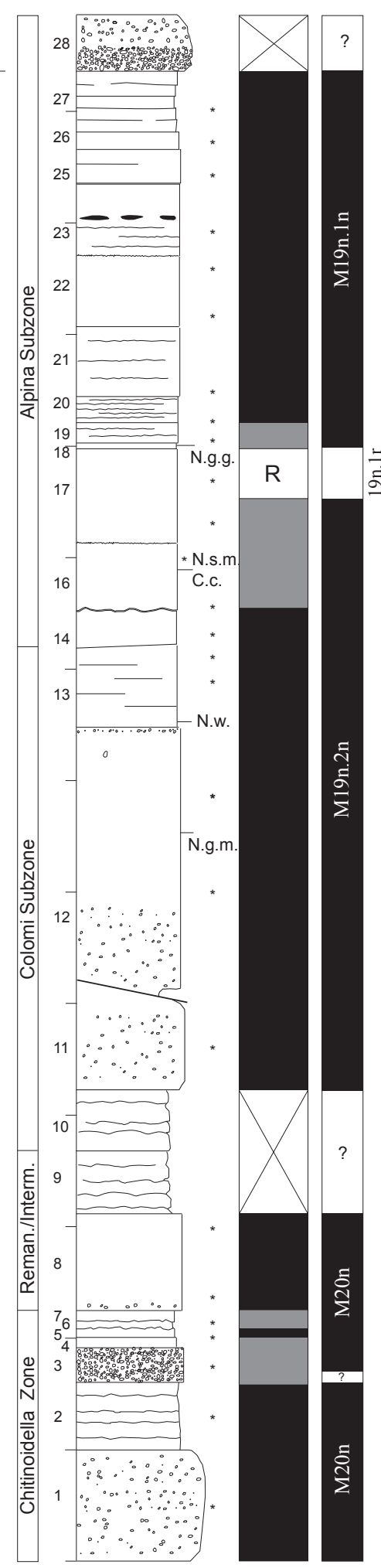

Fig. 8. Magnetostratigraphy of the Tré Maroua profile (lower (B; right) and lower-upper (A; left) sections, plus first occurrences of selected calcareous nannofossil first occurrences (FOs)

Black - normal polarity, white - reversed polarity, grey - no clear ChRM or remagnetization, cross - no palaeomagnetic samples. The declinations and inclinations of the ChRM in the Belvedere, Charens and Tré Maroua sections are presented in Figure 16.

Nannofossil abbreviations:

N.s.s. - Nannoconus steinmannii steinmannii; N.s.m. - Nannoconus steinmannii minor, N.w. Nannoconus wintereri; N.e. - Nannoconus erbae; N.g.m. - Nannoconus globulus minor, N.g.g. Nannoconus globulus globulus; N.k.m. - Nannoconus kamptneri minor, N.k.k. - Nannoconus kamptneri kamptneri; C.s. - Cretarhabdus surirelIus; C.o. - Cretarhabdus octofenestratus; C.c. Cruciellipsis cuvillieri; H.s. - Hexalithus strictus [=H. geometricus]

In the Calcaires Blancs, in the Crassicollaria Zone and Alpina and Ferasini subzones (Calpionella Zone), well- or massive-bedded biomicrites (wackestones) predominate, with minor bioclastic/intraclastic (calcarenite) units, and occasional cherts (Figs. 5, 6). Above, in the Elliptica Subzone, the sediments change, to alternating well-bedded biomicrites and marls. The micrites of the Calcaires Blancs Formation often yield abundant remains of microfauna and flora, notably calpionellids, calcareous nannofossils, calcareous dinocysts, but also calcified radiolaria and foraminifera. In the Vocontian Basin profiles, radiolarians are not uncommon, and are typical in some microfacies (see Wimbledon et al., 2020a), but they are of low diversity and mostly calcified, and thus not particularly useful.

The magnetostratigraphy, calpionellids and calcareous nannofossil distributions of all the studied Vocontian Basin sites have been summarised in Part 1 of this work (Wimbledon et al., $2020 \mathrm{~b}$ ), and are shown again below (there compared to sites in other regions).

The time period covered by the immediate boundary interval, the Colomi 


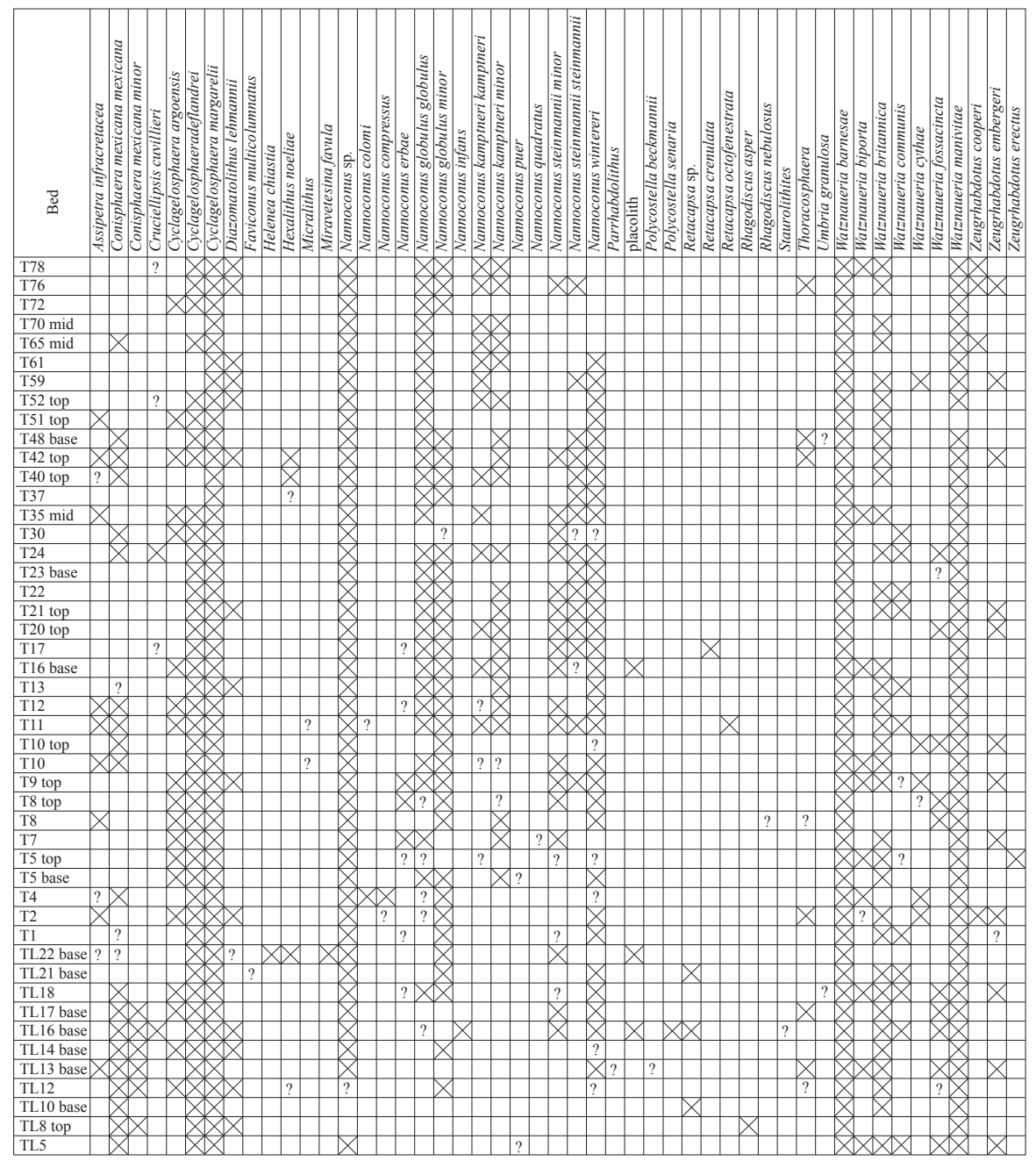

Fig. 9. Calcareous nannofossil occurrences at Tré Maroua, assigned to beds

Samples with prefix TL from the lower section and T from the upper section

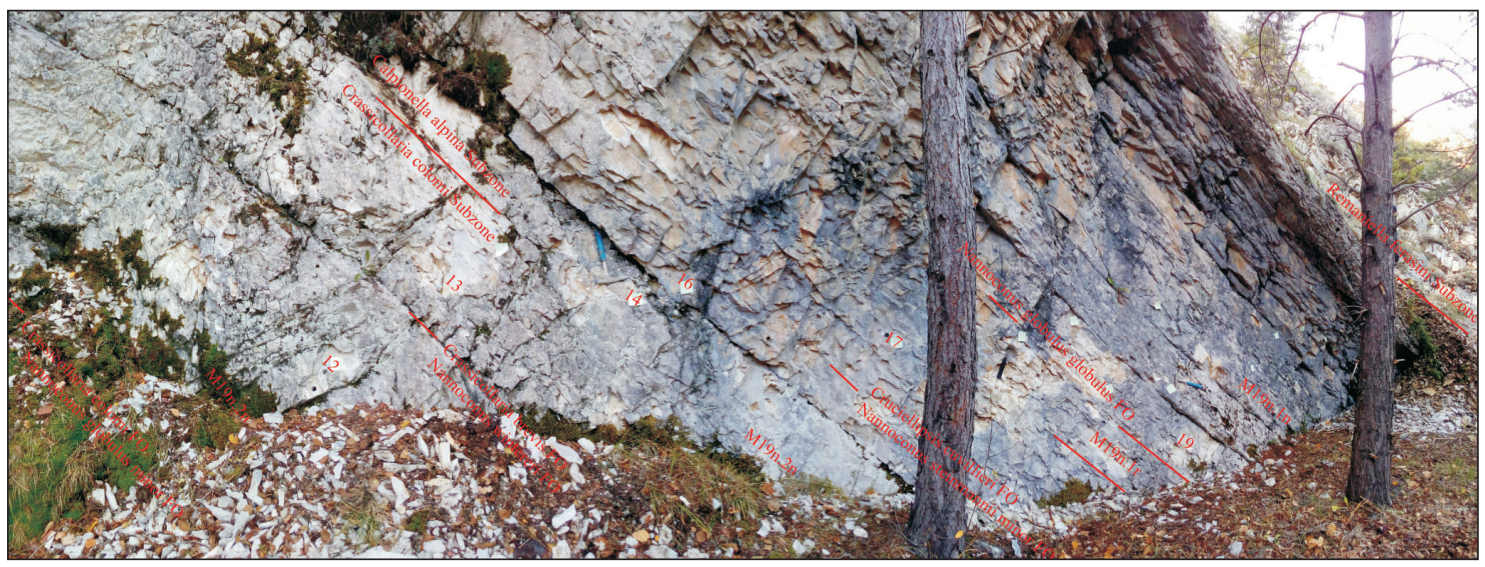

Fig. 10. Photograph of Tré Maroua GSSP profile with key datums indicated

The base of the Calpionella alpina Subzone, nannofossil markers and magnetozone boundaries are indicated 
and Alpina subzones combined, is in the order of $1.4 \mathrm{my}$. Following Gradstein et al.'s calculations for the duration of magnetozones M19r and M19n (2012, table 5.4), the Colomi Subzone would be circa 675,000 years, with about 545,000 of that in the lower half of M19n.2n. The Alpina Subzone would have a duration of circa 725,000 years, comprising 545,000 years for the upper half of M19n.2n, plus a further 180,000 for M19n.1r and M19n.1n combined.

\subsection{CALPIONELLIDS}

The calpionellid biozonation of the Vocontian Basin sites has been extensively studied (see Part 1 for references) and the WG has added further to this plexus of data (references in Wimbledon et al., 2013, 2020a)

The Colomi and Alpina calpionellid subzones, the immediate boundary interval, are developed at Tré Maroua in an unexceptional way: species occurrences and ranges are typical for this interval (see Fig. 10). The geographically widespread turnover that marks the base of the Alpina Subzone is obvious. Calpionellid ranges from the Tré Maroua profile are shown in Figures 5 and 6, with those of calcareous dinoflagellate cysts. Photographs of selected calpionellid species identified from the locality are shown in Figure 11.

The part of the section studied at Tré Maroua starts in the Chitinoidella Zone and ends in the Simplex Subzone (Calpionellopsis Zone), but higher and lower units are exposed. Here we focus, particularly, on the Colomi to Ferasini subzonal interval, as it brackets the Alpina Subzone and its base, the Tithonian/Berriasian stage boundary. The integration of calpionellid zonations with magnetostratigraphy and other biostratigraphies in the local Vocontian sections is shown in Part 1 (Wimbledon et al. 2020b, fig. 3). Wider calpionellid correlations (and nannofossil FOs) are shown herein (see also Wimbledon et al., 2020a). Zonal definitions used here follow well-established usage: defining authors for each biozone are cited below (also see discussion on zonal definitions in Lakova, Petrova, 2013).

\section{Upper Tithonian \\ Crassicollaria Zone, Colomi Subzone (sensu Pop, 1994) - beds 10-13}

Tré Maroua may be taken as typical of the other local Vocontian sites - Le Chouet, Charens, Belvedere and St Bertrand. Biomicrite limestones are predominantly wackestones (SMF 3, SMF 4). Calpionellid associations contain more frequent Crassicollaria parvula Remane and
Calpionella alpina Lorenz and rare Crassicollaria massutiniana (Colom), Cr. colomi Doben, Cr. intermedia (DurandDelga), Calpionella grandalpina Nagy, C. elliptalpina Nagy and Tintinnopsella carpathica (Murgeanu and Filipescu). In some material, the loricae are deformed. Calpionellids are accompanied by spores of Globochaete alpina Lombard, rare cysts of Stomiosphaerina proxima Řehánek, Colomisphaera fortis Řehánek, Stomiosphaera sp., fragments of ostracods, bivalves, crinoids (with a few Saccocoma sp.), aptychi, foraminifera (Spirillina sp.) and calcified radiolarians. At this level larger forms of the genus Calpionella and also saccocomids show a rapid decline, leading to their extinction - as has been documented in the majority of Tethyan sections (Wimbledon et al., 2013; Michalík et al., 2016; Hoedemaeker et al., 2016; Svobodová et al., 2019; KowalKasprzyk, Reháková, 2019). The matrix contains silty quartz and muscovite. Evidence for a few erosional events was observed in the Le Chouet and Charens profiles - limestone samples in thin section contain thin to thick laminae rich in small fragmented bioclasts. In the Tré Maroua section, bed 13 (Fig. 5B) belonging to this subzone contains a few small lithoclasts (unfossiliferous mudstone) and one small ooid. One microbreccia was overlooked in our earlier account of Vocontian basin sites: it forms the top of bed 12 at Tré Maroua, and is zero to $0.05 \mathrm{~m}$ thick (Fig. 5B).

Results from new sampling in the 2019 field season has led us to place the base of the Colomi Subzone a few centimetres higher than earlier published (Wimbledon et al., 2020a), at the base of bed 10 (Fig. 5B).

A single calpionellid-bearing sample from bed 12 has been studied (Granier et al., 2020, their sample 51), and, disagreeing with earlier accounts, assigned to the Alpina Subzone (Calpionella Zone). However, it appears that what was described is simply an unusual (reduced) Colomi Subzone (Crassicollaria Zone) assemblage. This is apparent because normal, more varied, groupings of species attributable to the Crassicollaria Zone are found in beds above this: characteristic Colomi Subzone assemblages are recorded at eight levels in beds 12 and 13 (Fig. 5B: also see Fig. 7). The same authors (Granier et al., op. cit.) record very thin intervals with limestone clasts in beds 16, 18 and basal 21 (not shown in fig. 4 of Wimbledon et al., 2020a): the thicknesses of these developments is too small to adequately depict them with the scale used here, but their levels are indicated (with an " $x$ " in Fig 5B herein).

Upstream in the Tré Maroua torrent, circa $10 \mathrm{~m} \mathrm{SW}$ of the Tré Maroua lower section and the main studied outcrops, accessory exposures have yielded further data from the Crassicollaria Zone. Figure 7 shows a comparison of the right-bank outcrop, and the ranges there of calpionellid species in beds 10 to 13. As can be seen from Figure 7, the assemblages of calpionellids (samples FS 4a-14) found indi- 

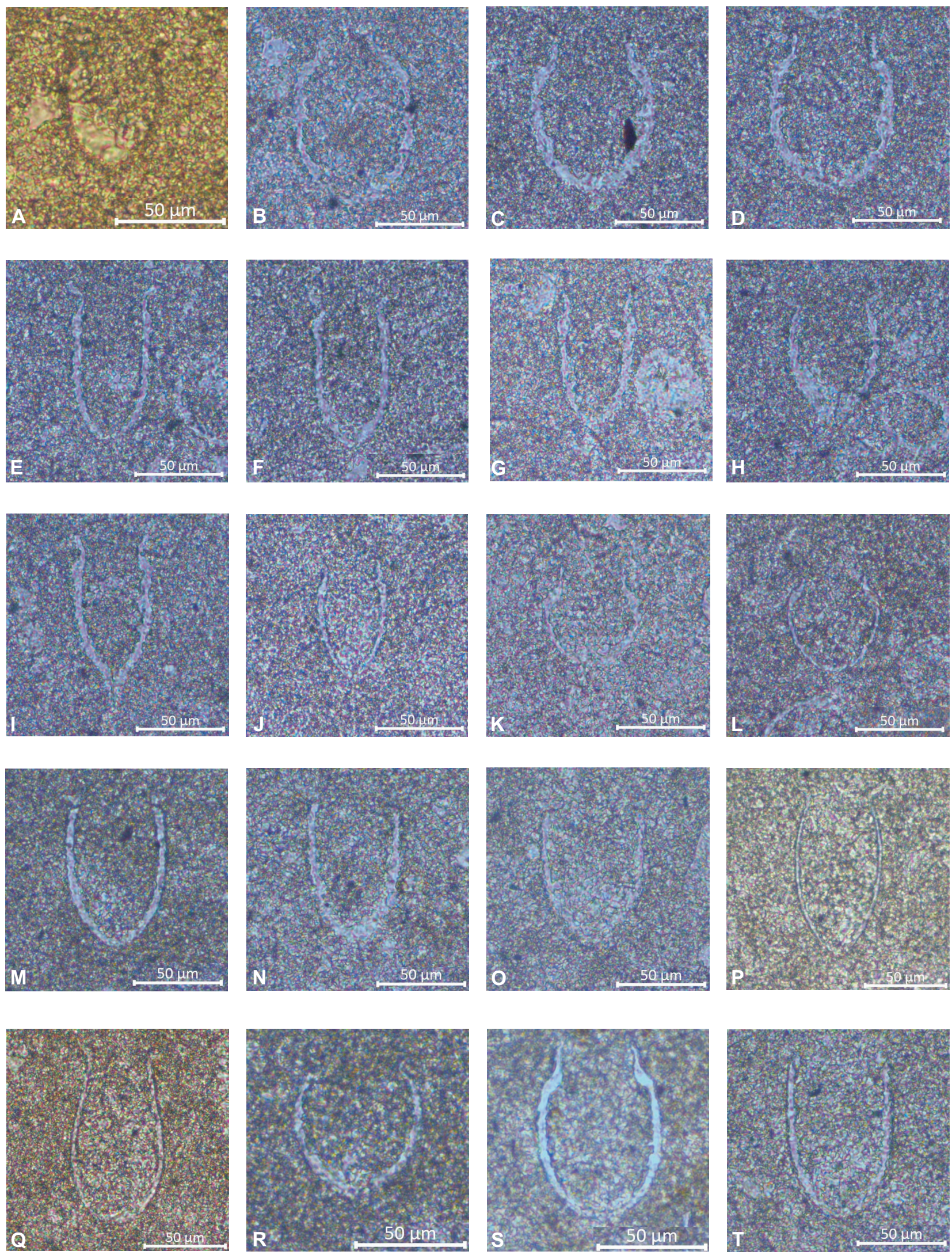
Fig. 11. Important calpionellid species in the $\mathrm{J} / \mathrm{K}$ boundary interval at Tré Maroua and related local sites

A - Chitinoidella boneti Doben. Sample R 2016/34; B - Calpionella elliptalpina Nagy. Sample TL 11b; C - Calpionella alpina Lorenz. Sample TL 8; D Calpionella grandalpina Nagy. Sample TL 11b; E - Crassicollaria intermedia (Durand Delga). Sample TL 8; F - Crassicollaria massutiniana (Colom). Sample T 11; G - Crassicollaria parvula Remane. Sample TL 12; H - Tintinnopsella carpathica (Murgeanu and Filipescu), small form. Sample T 12; I - Crassicollaria colomi Doben. Sample TL 12t; J - Crassicollaria parvula Remane. Sample TL 13; K, L - Calpionella alpina Lorenz, small forms. Sample TL 14; M - Remaniella ferasini (Catalano). Sample B 33; N - Remaniella catalanoi Pop. Sample B 35; 0 - Remaniella colomi Pop. Sample SBR 43 t; P - Tintinnopsella carpathica (Murgeanu and Filipescu), large form. Sample T 126 t; Q - Tintinopsella longa (Colom). Sample T 116t; R - Lorenziella hungarica Knauer and Nagy. Sample SB 49t; S - Calpionella elliptica Cadisch. Sample SB 86 b; T - Calpionellopsis simplex (Colom). Sample T 122t.

TL prefaces the bed number for the lower Tré Maroua profile, and T beds in the upper profile. SC - Saint Bertrand, SBR - Saint Bertrand Ridge, and B Belvedere

cate the presence of the Colomi Subzone. The primary data and the biozones interpreted correspond to those previously recorded for the GSSP section (Fig. 5B).

\section{Lower Berriasian \\ Calpionella Zone, Alpina Subzone \\ (sensu Pop, 1974 and Remane, 1986) - beds 14-28}

As with the Crassicollaria Zone, Tré Maroua and the other nearby sections are closely similar in their development of the Alpina Subzone. Biomicrite, locally slightly bioturbated, predominate (wackestone; SMF 3, SMF 4). Small species of Calpionella alpina dominate over rare to infrequent Crassicollaria parvula, Cr. massutiniana, Cr. brevis Remane, Tintinnopsella carpathica and T. doliphormis (Colom). Spores of Globochaete alpina, cysts of Colomisphaera lapidosa (Vogler), Col. carpathica (Borza), Col. fortis, Stomiosphaerina proxima, Stomiosphaera sp., microproblematicum Didemnum carpaticum Miš́k and Borza, fragments of ostracods, aptychi, rhyncholite, crinoids, foraminifera (Lenticulina sp., Spirillina sp., Dentalina sp.), calcified radiolarians and sponge spicules were observed. The matrix also contains deformed loricae and rare silty clastic admixure.

Microbreccia beds are documented in the higher part of the Alpina Subzone in the Charens, Le Chouet, the Saint Bertrand lower path and also in the Tré Maroua sections. At the first two sites, brecciated structure in thin-sections is not so distinct, whereas at the last-mentioned locality some thinsections (bed 6) are composed of reworked Kimmeridgian and Tithonian deposits - clasts of Saccocoma, Bositra - filamentous, Calpionella microfacies (wackestone), and clasts of bioclastic grainstones containing agglutinated foraminifera, miliolid foraminifera, fragments of algae, crinoids and recrystallized ooids.

The base of the Alpina Subzone, the primary marker for the base of the Berriasian, is located at the base of bed 14 in the lower (riverside) section at Tré Maroua (Fig. 5B), as illustrated in the annotated photograph (Fig. 10)

\section{Calpionella Zone, Ferasini Subzone (sensu Pop, 1994) - beds 7 to lower 16}

Biomicrite limestones (wackestone; SMF 3). Calpionellid associations consisted of Remaniella ferasini (Catalano), $R$. duranddelgai Pop, $R$. catalanoi Pop, $R$. colomi Pop, $R$. borzai Pop, Calpionella alpina, Crassicollaria parvula, Tintinnopsella carpathica, T. doliphormis, Lorenziella hungarica Knauer and Nagy, L. plicata Remane and the first elliptoidal species - Calpionella alpelliptica Nagy. They occur with spores of Globochaete alpina, cysts of Cadosina semiradiata fusca (Wanner), C. semiradiata semiradiata (Wanner), Colomisphaera lapidosa, Col. minutissima Nowak, Col. carpathica, Stomiosphaerina proxima, Stomiosphaera sp., fragments of ostracods, bivalves, crinoids, ophiurids, Spirillina sp., Bullopora sp., calcified radiolarians, spicules. Locally rare silty quartz grains are visible in the matrix.

\section{Calpionella Zone, Elliptica Subzone (sensu Pop, 1974) - beds upper 16 to 99}

Biomicrite limestones (wackestone to mudstone; SMF 3). Limestones contain calpionellids: Calpionella elliptica Cadisch, C. alpina, C. minuta Houša, Crassicollaria parvula, Lorenziella hungarica, L. plicata, Remaniella catalanoi, R. ferasini, R. duranddelgai, R. borzai, R. colomi, Tintinnopsella carpathica, T. doliphormis, T. longa (Colom), Borzaiella atava Grün and Blau, spores of Globochaete alpina, cysts of Cadosina semiradiata fusca, Colomisphaera minutissima, Col. lapidosa, Col. carpathica, Stomiosphaera cf. wanneri, St. moluccana, Stomiosphaera sp., calcified radiolarians, fragments of ostracods (also with ornamented shells), bivalves, crinoids, and foraminifera (Spirillina sp., Lenticulina $\mathrm{sp}$.). The matrix is locally slightly silicified, it contains rare, silty, clastic quartz, scattered pyrite (locally also framboidal) which forms nest concentrations or pyrite impregnated bioclasts. A few phosphatized bioclasts were also observed. In some samples, high-amplitude stylolites 
are filled with Fe-hydroxides, and a few small structures resembling frutextite growths were documented in the matrix. (Simplex Subzone calpionellids have been described in Wimbledon et al., 2020a)

\subsection{CALCAREOUS NANNOFOSSILS}

The succession of nannofossil FOs in Vocontian basin and other sections that has been elucidated in the last ten years has been discussed recently (Wimbledon et al., 2020a, b, updating Wimbledon, 2017).

First occurrences (FOs) of stratigraphically significant calcareous nannofossils at Tré Maroua are shown in Figures 8 and 9. The species Nannoconus wintereri, N. steinmannii minor, N. kamptneri minor, N. globulus globulus, Cruciellipsis cuvillieri, N. kamptneri kamptneri, and N. steinmannii steinmannii have all been recorded. Selected nannofossil species are illustrated in Figure 12,

FOs of useful nannofossil species in M19n may be examined relative to the base of magnetosubzones M19n.2n and M19n.1r, and the base of the Calpionella alpina Subzone. As shown in Figures 8 and 9, nannofossil FOs close to the Tithonian/Berriasian boundary level at Tré Maroua match well with more recent records at other localities. The wider correlative context and the pattern of nannofossil species appearances is discussed in Part 1, and is shown below.

As demonstrated in Part 1 (fig. 2), Nannoconus wintereri FOs occur in a cluster in lower M19n.2n (at St Bertrand and Le Chouet); N. steinmannii minor FOs form a cluster just above the Alpina Subzone base at a number of sites (only at Rio Argos has it been seen lower), N. kamptneri minor occurs in another group in upper M19n (as at Le Chouet); and Cretarhabdus octofenestratus occurs in M18r, within the limited range that was previously identified for its FO. At
Tré Maroua, the $\mathrm{FO}$ of $N$. wintereri is within the $\mathrm{FO}$ cluster just below the base of the Alpina Subzone, and N. steinmannii minor is part of a FO cluster just above the Alpina Subzone base. N. kamptneri minor first appears in M19n.1n.

\subsection{FORAMINIFERA}

Foraminifera are less common at Tré Maroua, as is the case in other Vocontian successions - the limited finds encountered are as follows:

TL 2 top - lagenid foraminifera

TL 4 - foraminifera indet.

TL 5 - foraminifera indet.

TL 7 - Spirillina sp., Dentalina sp., Bullopora sp.

TL 8 - Spirillina sp., Dentalina sp., Lenticulina sp., Neotrocholina $\mathrm{sp}$

TL 10, TL 12 lower, TL 12 - Spirillina sp.

TL 14 - Lenticulina sp.

TL 16 - Spirillina sp., Dentalina sp.

TL 19 - Bullopora sp.

TL 21 - Spirillina sp.

TL 22 - Lenticulina sp., Dentalina sp., Spirillina sp.

TL 23 - Lenticulina sp., Spirillina sp.

TL 26, TL 27 - Spirillina sp.

T 4, T 5, T 5, T 10 - Spirillina sp.

T 11 - Spirillina sp., Bullopora sp.

T 22, T 23, T 24, T 35 - Spirillina sp.

T 37 - Spirillina sp., Lenticulina sp.

T 40, T 48, T 51 - Spirillina sp.

T 89 - object resembling a planktonic foraminiferan

T 126 - Spirillina $\mathrm{sp}$.

The prefix TL refers to sample bed numbers in the lower section, and $\mathrm{T}$ to upper section samples.

Fig. 12. Selected taxa of calcareous nannofossils

Photographs in cross polarized light, figures $N, P, R, U, V, X, Z, A B, A D, A E, A F, A H$ and $A J$ in plane polarized light. The scale bar represents 5 microns.

A - Cyclagelosphaera argoensis Bown, 1992. Tré Maroua, sample TL 12; B - Cyclagelosphaera deflandrei (Manivit, 1966) Roth, 1973. Charens, sample R 13; C - Cyclagelosphaera margerelii Noël, 1965. Tré Maroua, sample T 30; D - Diazomatolithus lehmanii Noël, 1965. Beaume, sample B 40; E - Watznaueria barnesiae (Black in Black \& Barnes, 1959) Perch-Nielsen, 1968. Tré Maroua, sample T 2; F - Watznaueria britannica (Stradner, 1963) Reinhardt, 1964. Tré Maroua, sample T 9t; G - Watznaueria cynthae Worsley, 1971. Tré Maroua, sample T 2; H - Watznaueria manivitiae Bukry, 1973. Charens, sample R2016/39; I - Cruciellipsis cuvillieri (Manivit, 1956), Thierstein, 1971. Tré Maroua, sample TL 16; J - Zeugrhabdothus embergerii (Noël, 1958) Perch-Nielsen, 1984. Charens, sample R 3; K - Assipetra infracretacea (Thierstein, 1973) Roth, 1973. Tré Maroua, sample TL 13; L - Conusphaera mexicana (Trejo, 1969) subsp. mexicana Bralower in Bralower et al., 1989. Tré Maroua, sample TL 12; M, N - Nannoconus puer Casellato, 2010. Charens, sample R2016/9, the same specimen; 0, P - Nannoconus globulus (Brönnimann, 1955) subsp. minor Bralower in Bralower et al., 1989. Tré Maroua, sample T 4, the same specimen; Q, R - Nannoconus globulus (Brönnimann, 1955) subsp. globulus Bralower in Bralower et al., 1989. Tré Maroua, sample T 11, the same specimen; S - Faviconus multicolumnatus Bralower in Bralower et al., 1989. Charens, sample R2016/27; T - Polycostella beckmannii Thierstein, 1971. Charens, sample R2016/16; U, V - Nannoconus wintereri Bralower \& Thierstein in Bralower et al., 1989. Tré Maroua, samples T 11 and T 35 m; W-Z - Nannoconus steinmannil (Kamptner, 1931) subsp. minor Deres \& Achéritéguy, 1980. W, X - Tré Maroua, sample TL 16, the same specimen. Y, Z - Beaume, sample B 35, the same specimen; AA-AD - Nannoconus kamptneri (Brönnimann, 1955) subsp. minor Bralower in Bralower et al., 1989; AA, AB - Beaume, sample B 40, the same specimen; AC, AD - Tré Maroua, sample T 8, the same specimen; AE, AF - Nannoconus kamptneri (Brönnimann, 1955) subsp. kamptneri Bralower in Bralower et al., 1989. Tré Maroua, sample T 24; AG-AJ - Nannoconus steinmannii (Kamptner, 1931) subsp. steinmannii Deres \& Achéritéguy, 1980; AG, AH - Tré Maroua, sample T 24, the same specimen; AI, AJ - Tré Maroua, sample T 23b, the same specimen 


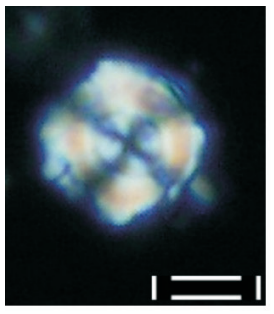

A
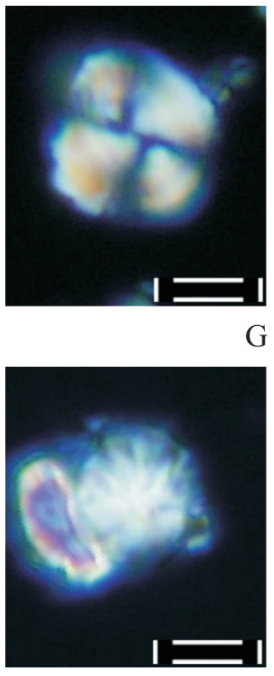

M
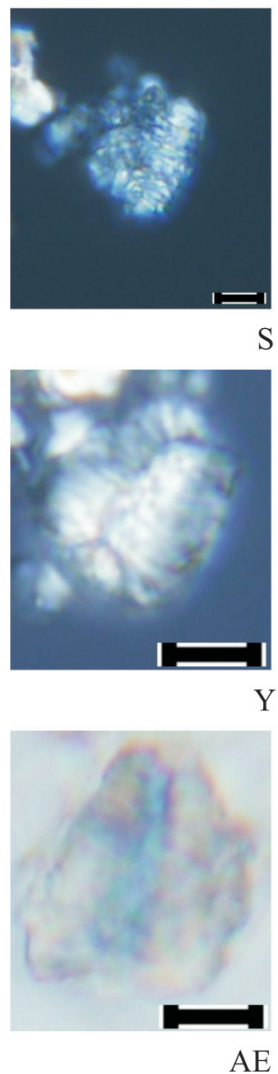
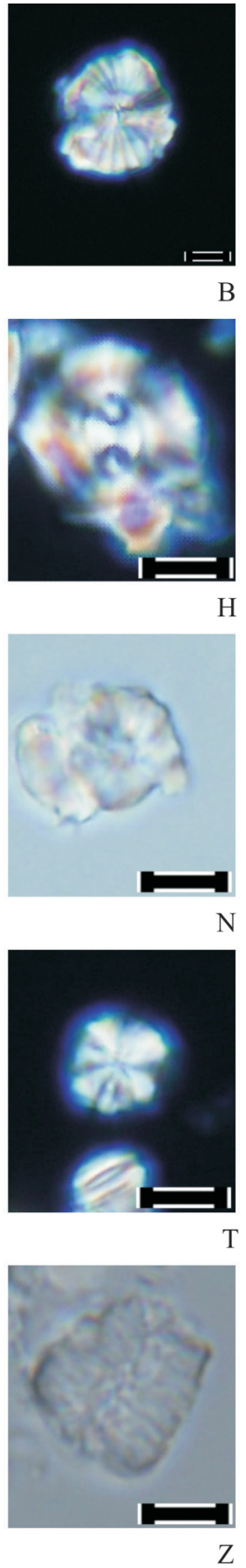

$\mathrm{N}$
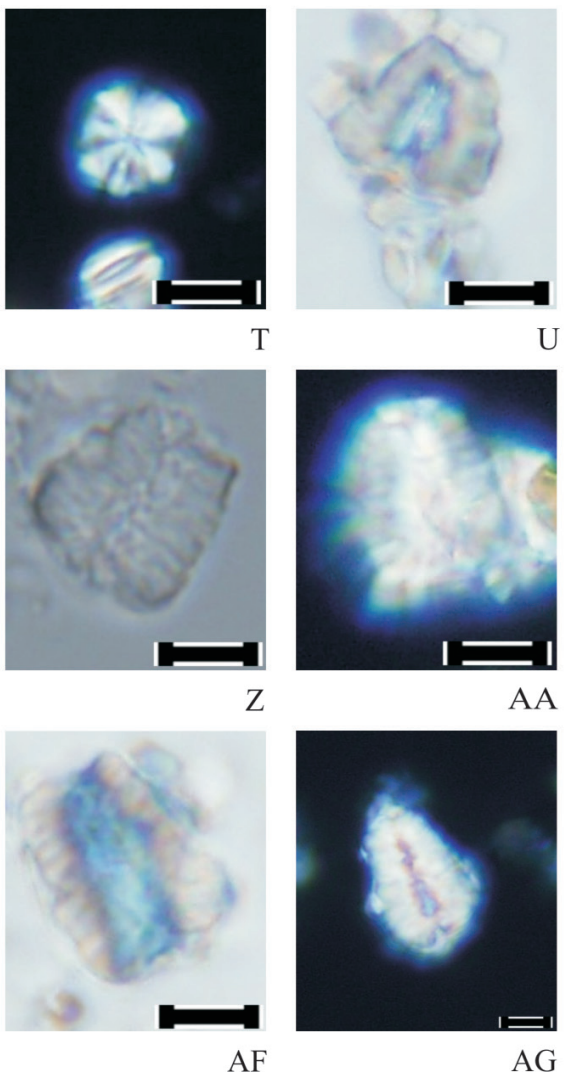
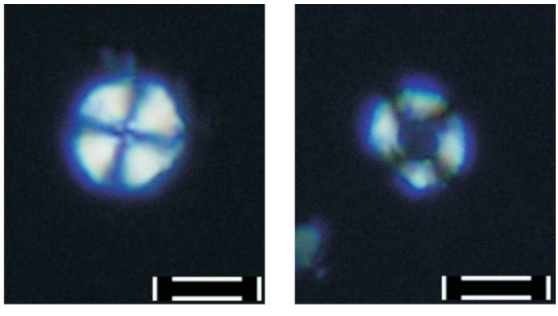

C
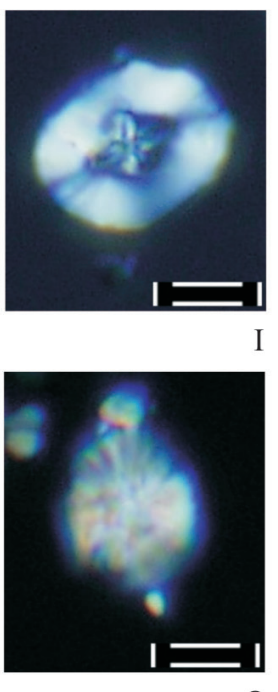

O
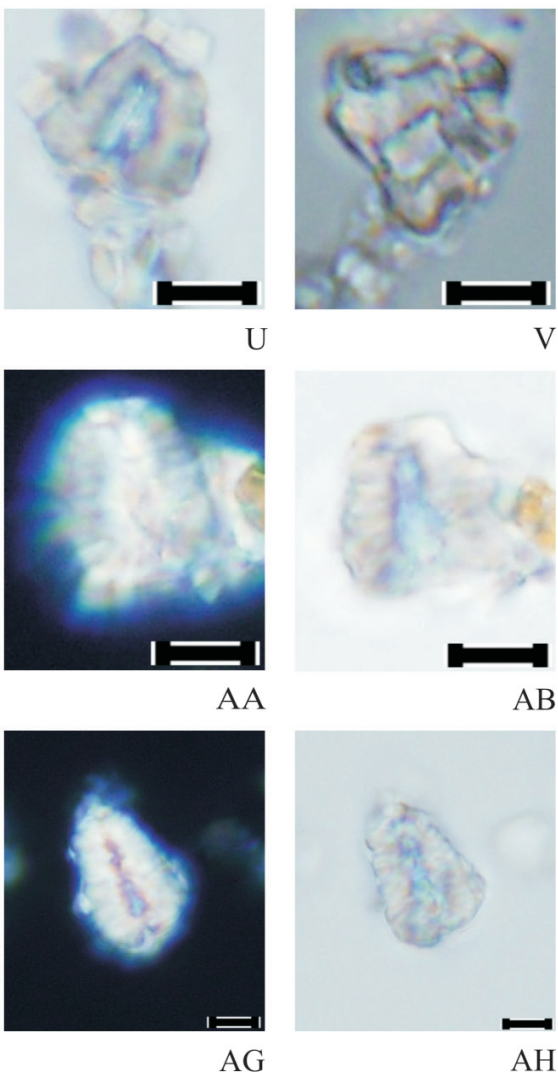

D
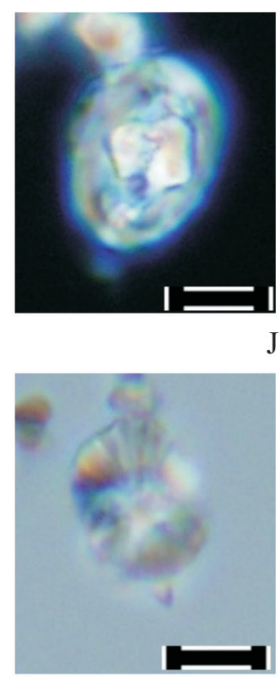
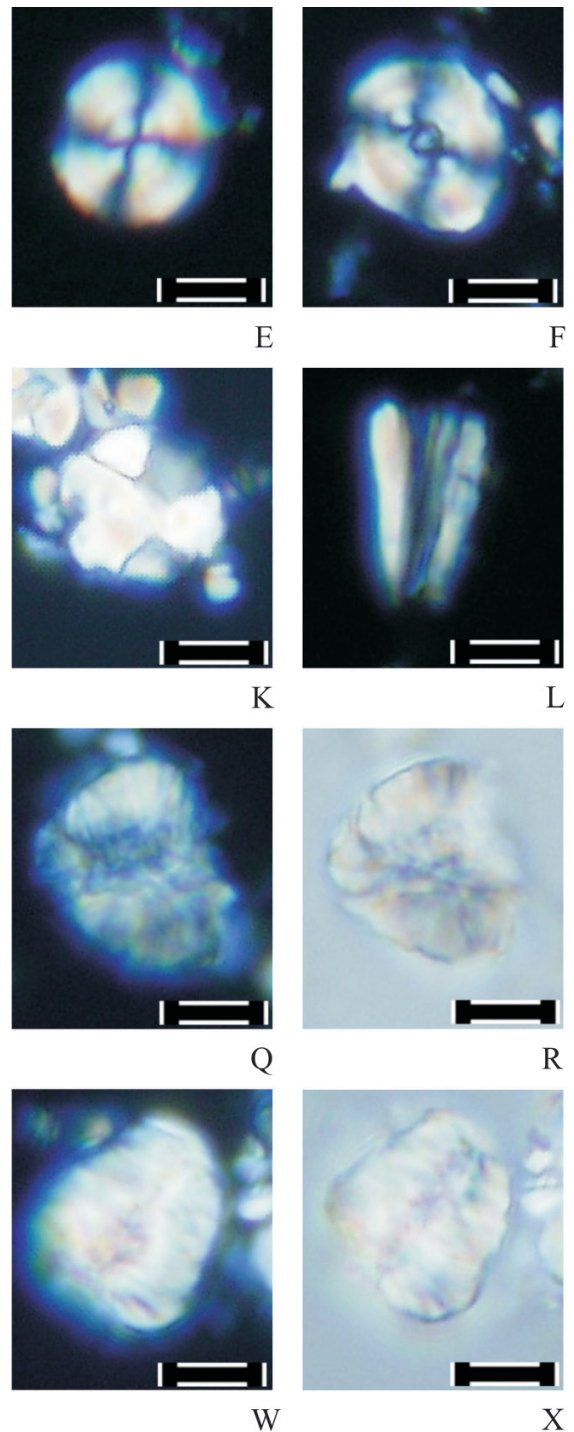

E
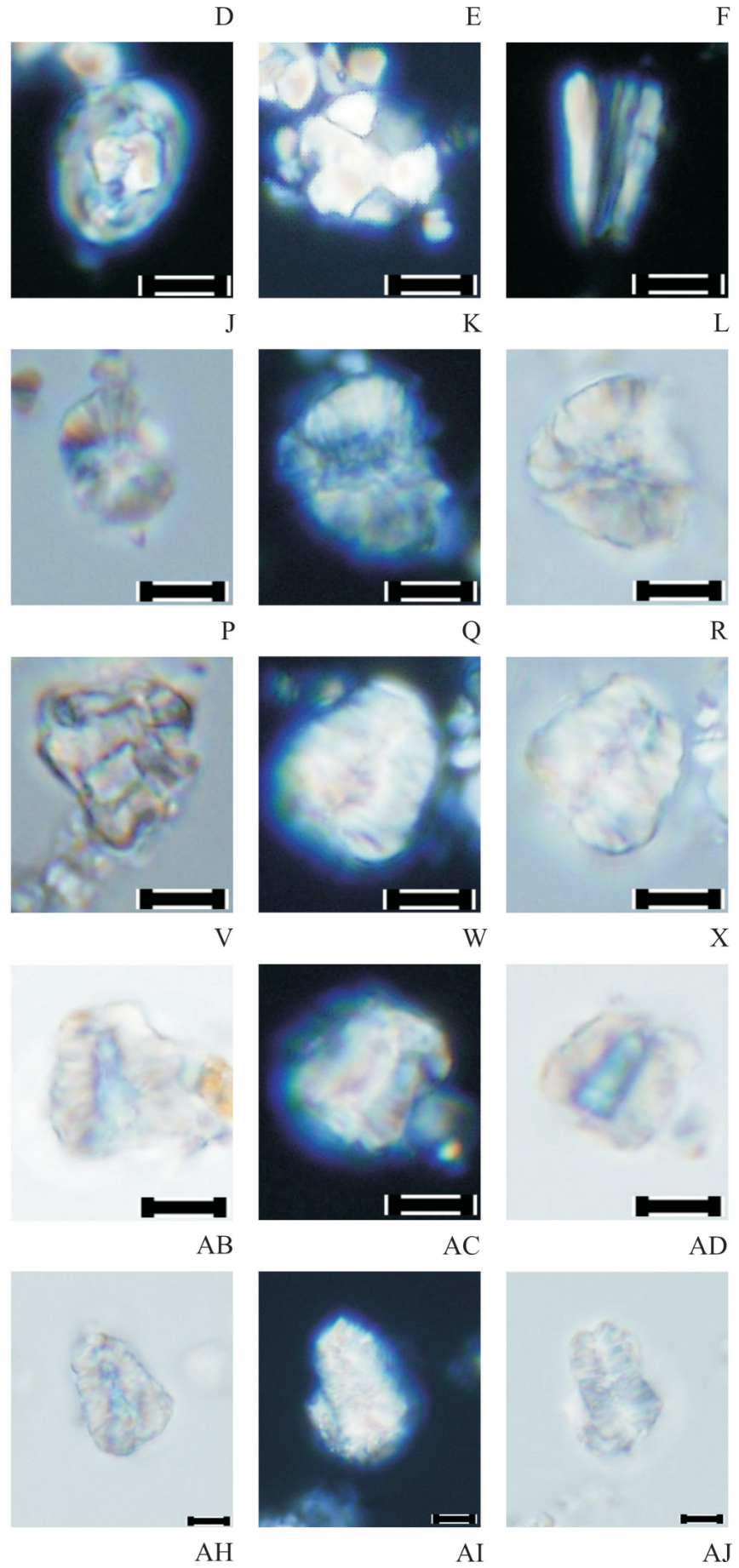


\subsection{AMMONITES}

Ammonite faunas in the studied sites between Luc en Diois and Gap have already been documented in recent times (Bulot et al., 2014; Frau et al., 2015, 2016a-c; Wimbledon et al., 2013).

Four successive post-Andreaei Zone assemblages can be identified in the lowest Berriasian of the Vocontian basin sites: from oldest to youngest, an Elenaella cularense assemblage, and then assemblages, in succession, dominated by Praedalmasiceras, by Delphinella (with the earliest Pseudosubplanites), by Pseudosubplanites, and then, lastly, one dominated by Strambergella, including Strambergella jacobi and S. carpathica.

Ongoing bed-by-bed collecting at Tré Maroua has yielded the ammonites listed below (phylloceratids, lytoceratids and haploceratids excluded). Though present at other sites, such as Le Chouet and Saint Bertrand, latest Tithonian Elenaella cularense has not so far been proved at Tré Maroua. However, the genus Delphinella, which is a reasonable ammonite proxy for the base of the Alpina Subzone, and the base of the Berriasian, is present here. The ammonite fauna collected thus far is as follows:

\section{Lower section}

Bed

17 Delphinella gr. delphinense Kilian [m]

18 Berriasella gr. oppeli (Kilian) - moreti Mazenot [m]

23 top Berriasella gr. oppeli (Kilian) - moreti Mazenot [m] Praedalmasiceras cf. progenitor (Oppel) [m]

\section{Upper section}

Bed

8 Delphinella gr. delphinense Kilian [m]

Berriasella gr. oppeli (Kilian) - moreti Mazenot [m]

Proniceras pronum (Oppel) [m]

$9 \quad$ Delphinella gr. delphinense Kilian [m]

Berriasella gr.oppeli (Kilian) - moreti Mazenot [m]

11 Pseudosubplanites gr. lorioli (Zittel) $[\mathrm{m}+\mathrm{M}]$

$12 \quad$ Pseudosubplanites gr. lorioli (Zittel) $[\mathrm{m}+\mathrm{M}]$

19 Hegaratella gr. pontica (Retowski) $[\mathrm{m}+\mathrm{M}]$

Pseudosubplanites gr. lorioli (Zittel) [m]

21 Retowskiceras sp. juv.

Pseudoneocomites retowskyi (Sarasin \& Schönderlmayer) [m]

$24 \quad$ Strambergella carpathica (Zittel) $[\mathrm{m}]$
$31 \quad$ Strambergella jacobi (Mazenot) [M]

Bochianites sp. juv.

$35 \quad$ Strambergella jacobi (Mazenot) sp. juv.

$36 \quad$ Strambergella jacobi (Mazenot) $[\mathrm{m}+\mathrm{M}]$

Bochianites sp. juv.

42 Strambergella carpathica (Zittel) $[\mathrm{m}+\mathrm{M}]$

Strambergella cf. carpathica (Zittel) [M]

51 Delphinella gr. ellenica Nikolov [m]

60 Tirnovella gr. occitanica (Pictet) [m]

77 Delphinella gr. ellenica Nikolov [M]

89 Delphinella gr. ellenica Nikolov [m]

Berriasella privasensis (Pictet) [m]

Proniceras sp. [m]

$94 \quad$ Mazenoticeras aff. broussei (Mazenot)[M]

96 Delphinella gr. ellenica Nikolov [m]

100 Dalmasiceras gr. dalmasi (Pictet) [m]

105 Dalmasiceras gr. dalmasi (Pictet) [m]

Jabronella patruliusi Le Hégarat [?m]

114 "Mazenoticeras" cf. gigondasense (Steinmann)

Figures 13 and 14 show selected ammonite species from Tré Maroua.

As already documented at Saint Bertrand, at Tré Maroua the stratigraphic appearance of Strambergella jacobi is well above basal Berriasian levels - in fact, in the upper part of the Calpionella Zone (see Part 1): rendering S. jacobi problematical as a marker for the lowest Berriasian, and unsuitable as an index species for the lowest zone of the stage. A new ammonite zonal scale for the Lower Berriasian is thus urgently needed (Frau in Reboulet et al., 2018).

Above the Strambergella assemblage, the faunas are impoverished until levels where Berriasella privasensis and a Dalmasiceras dalmasi assemblage are recorded. The latter being characteristic in southeast France of the middle and upper parts of the Tirnovella occitanica assemblage zone, as defined by Le Hégarat (1973).

\subsection{MAGNETOSTRATIGRAPHY}

The numerous studies of $\mathrm{J} / \mathrm{K}$ sequences in Tethys, often determining palaeomagnetic polarity boundaries on a centimetric scale, have built a solid and uniform set of palaeomagnetic data - which are a powerful constraint on, and complement to, biostratigraphy (see Part 1). Actually, the

\section{Fig. 13. Selected ammonites from Tré Maroua}

A - Delphinella gr. delphinense, TM.9.1 [m]; B - Delphinella gr. delphinense, TM.9.2 [m]; C - Praedalmasiceras cf. progenitor, TM.23t.1 [m]; D - Proniceras pronum, TM.8.4 [m]; E - Berriasella gr. oppeli - moreti, TM.8.5 [m]; F - Berriasella gr. oppeli - moreti, TM.9.4 [m]; G - Pseudoneocomites retowskyi, TM.21b.1 [m]; H - Pseudosubplanites gr. lorioli, TM.12.1a [M]; I - Pseudosubplanites gr. lorioli, TM.19.4 [m]; J - Hegaratella gr. pontica, TM.19b.1 [M]; K - Hegaratella gr. pontica, TM.19.3 [m]; L - Strambergella jacobi, TM.31.2 [M]; M - Strambergella jacobi, TM.36.3 [m]; N - Strambergella jacobi, TM.36.1 [m]; 0 - Strambergella carpathica, TM.42.3 [M]; P - Strambergella carpathica, TM.35.2 [m]; Q - Strambergella carpathica, TM.42.1 [m].

First numbers of the labels indicate the bed. Due to compaction, photographs of the venter are difficult in most cases. 


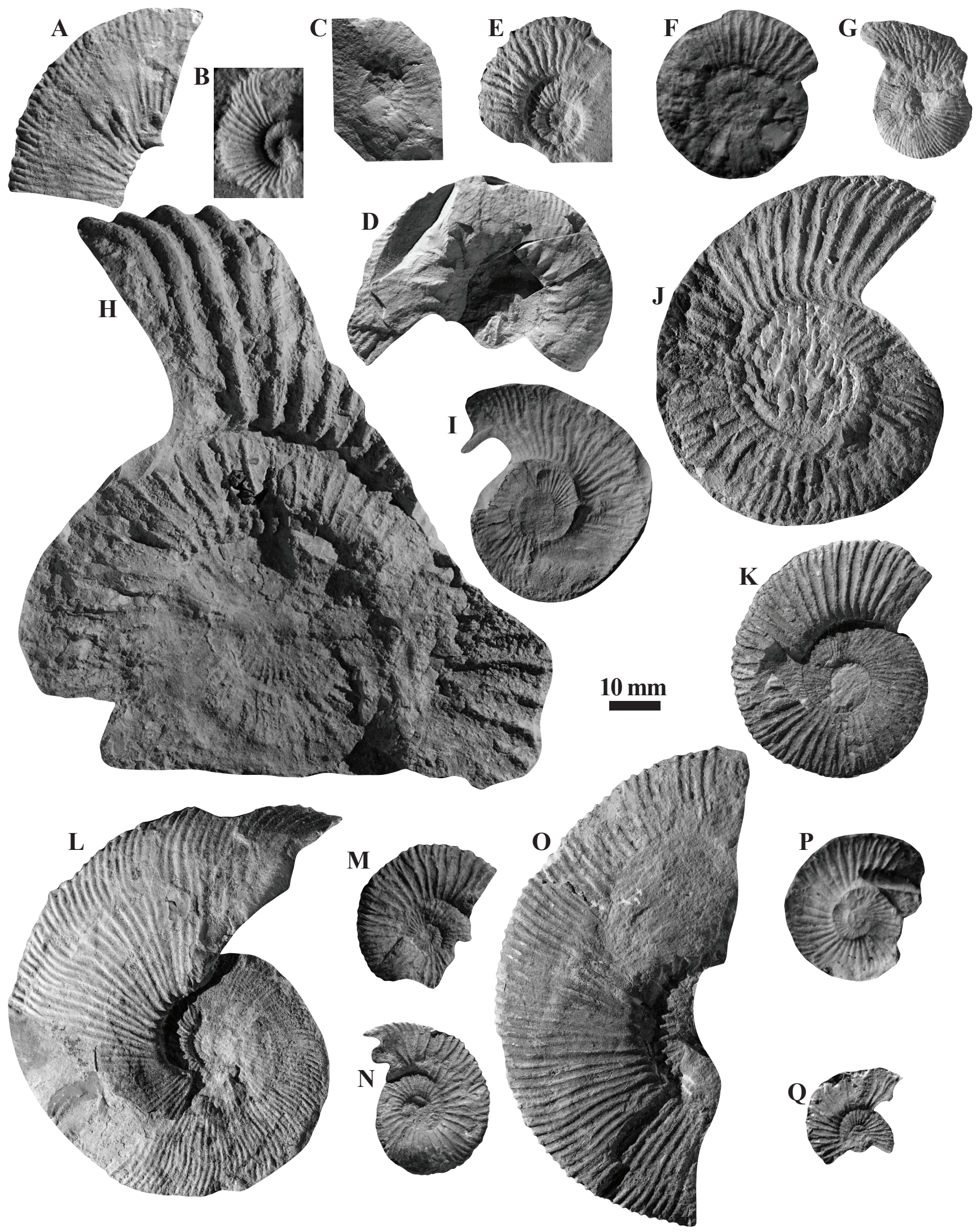




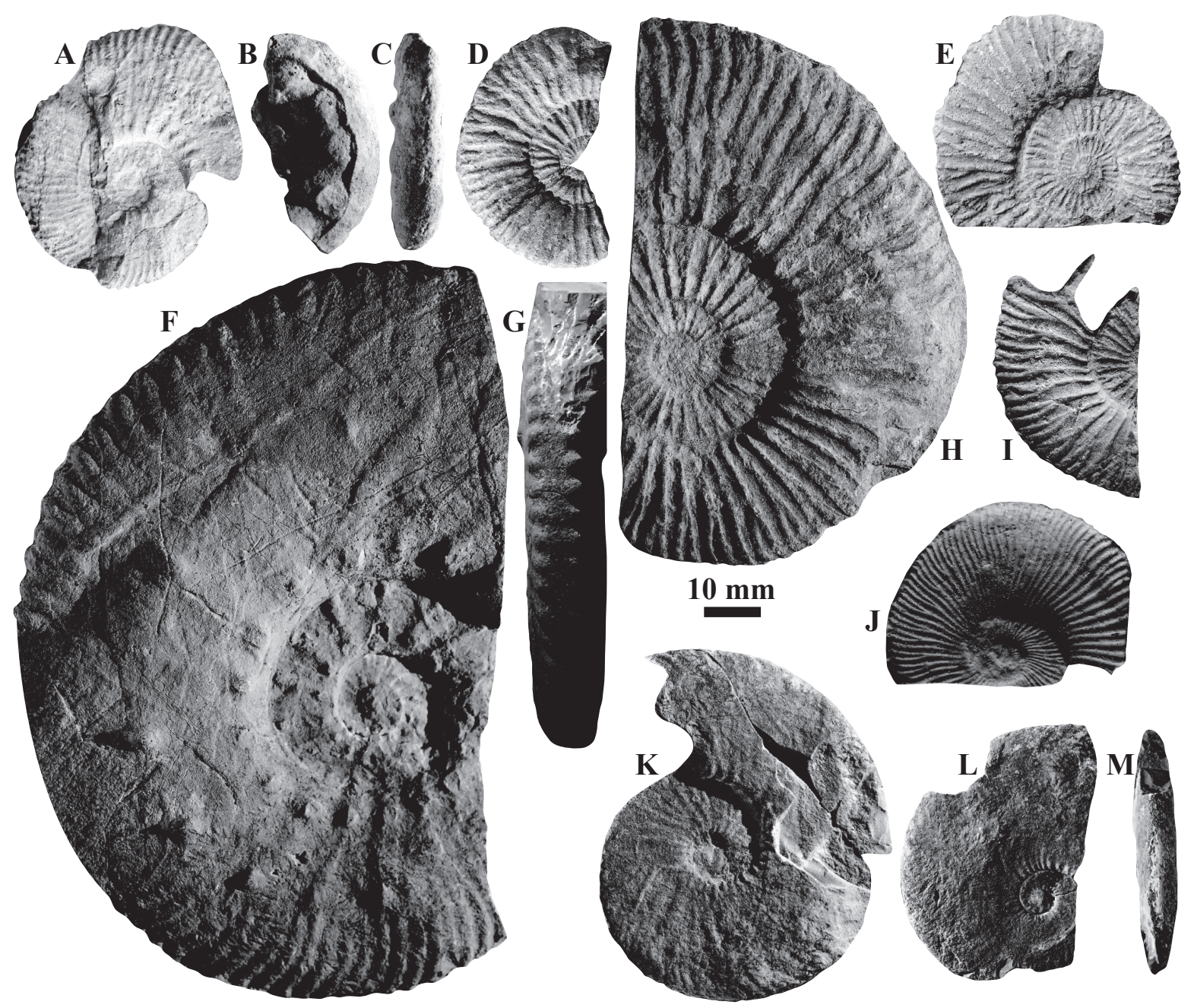

Fig. 14. Selected ammonites from Tré Maroua

A - Tirnovella gr. occitanica, TM.60.1 [m]; B. C - "Mazenoticeras" cf. gigondasense, TM.114.1; D - Berriasella privasensis, TM.89.2 [m]; E - Berriasella privasensis, TM.89.1 [m]; F, G - Mazenoticeras aff. broussei, TM.94.1, [M]; H - Delphinella gr. ellenica, TM.51.1 [M]; I - Delphinella gr. ellenica, TM.51.2 [m]; J - Jabronella patruliusi, TM.105.3 [?m]; K - Dalmasiceras gr. dalmasi, TM.105.1 [m]; L, M - Dalmasiceras gr. dalmasi, TM.100.1 [m].

First numbers indicate the bed. Due to compaction, photography of the venter is difficult in most cases

$\mathrm{J} / \mathrm{K}$ interval has a much larger high-quality palaeomagnetic data set than exists for most stratigraphic boundary intervals (and most previously selected GSSPs), and the TithonianBerriasian with its unique and distinctive normal and reversed pattern has been extremely productive for magnetostratigraphic study. Figures 15-18 herein are from a wider study on Vocontian Basin sites (Wimbledon et al., 2020a).

The limestones of the Tré Maroua outcrops and all the studied Vocontian Basin sections nearby show low magnetic susceptibilities (MS) and natural remanent magnetization (NRM) (Fig 18; Wimbledon et al., 2013, Elbra et al., 2018a). Dual polarity characteristic remanent magnetization (ChRM; Fig. 15), carried by magnetite, has been determined using principal component analysis and Fisher statistics (after Fisher, 1953; Kirschvink, 1980) in samples from all the sections, and this was used to construct the magnetostratigraphy.

Figure 8 shows the magnetostratigraphy at Tré Maroua, interpreted as comprising magnetozones between M21n and M17r. Magnetic properties, demagnetization characteristics, direction of remanent magnetisation etc. are shown in $\mathrm{Fi}$ gures $15-18$. Ninety-six palaeomagnetic samples were tested from the Tré Maroua sequence. A primary characteristic remanent magnetization component (ChRM; Fig. 17) has been found in 30 samples, and there it is carried by magnetite. Several samples also contain goethite, the product of we- 
athering, but this mineral does not carry ChRM. Goethiteand hematite-bearing samples were discarded for the purposes of magnetostratigraphic interpretation: only samples with a (magnetically) dominant amount of magnetite (Fig. 17), and containing the ChRM component, have been used in the interpretation of the section.

Palaeomagnetic data from the Tré Maroua section (Fig. 16) reveal the presence of four normal $\left(\mathrm{D}_{\mathrm{N}} 339^{\circ}\right.$ and $\left.\mathrm{I}_{\mathrm{N}} 37^{\circ}\right)$ and three reversed polarity (sub)zones $\left(\mathrm{D}_{\mathrm{R}} 133^{\circ}\right.$ and $\mathrm{I}_{\mathrm{R}}-58^{\circ}$; Fig. 15, 16). They are interrupted by intervals with no palaeomagnetic samples (beds 9, 10 and 28 in the lower, riverside, section (B), and beds 1-6 in the lower upper profile (A), or units with no clear or primary ChRM (in B). The upper pro- file (A) contains two reversed polarity intervals (beds 19-34 and beds 8-12). We interpret the former to be magnetozone M17r (it is in the Elliptica Subzone), and that the latter (Ferasini Subzone) belongs to M18r.

The top of the lower Tré Maroua section reveals the presence of a normally magnetized interval (beds 19-27), with, below, a short reversal and a second normal polarity zone (beds 11-16). The latter interval includes the Crassicollaria-Calpionella zonal boundary (base of the Alpina Subzone; bed 14, B) and belongs, therefore, to M19n2n. Based on the undoubted identification of M19n.2n, we assign the overlying interval to magnetosubzones M19n.1r and M19n.1n.

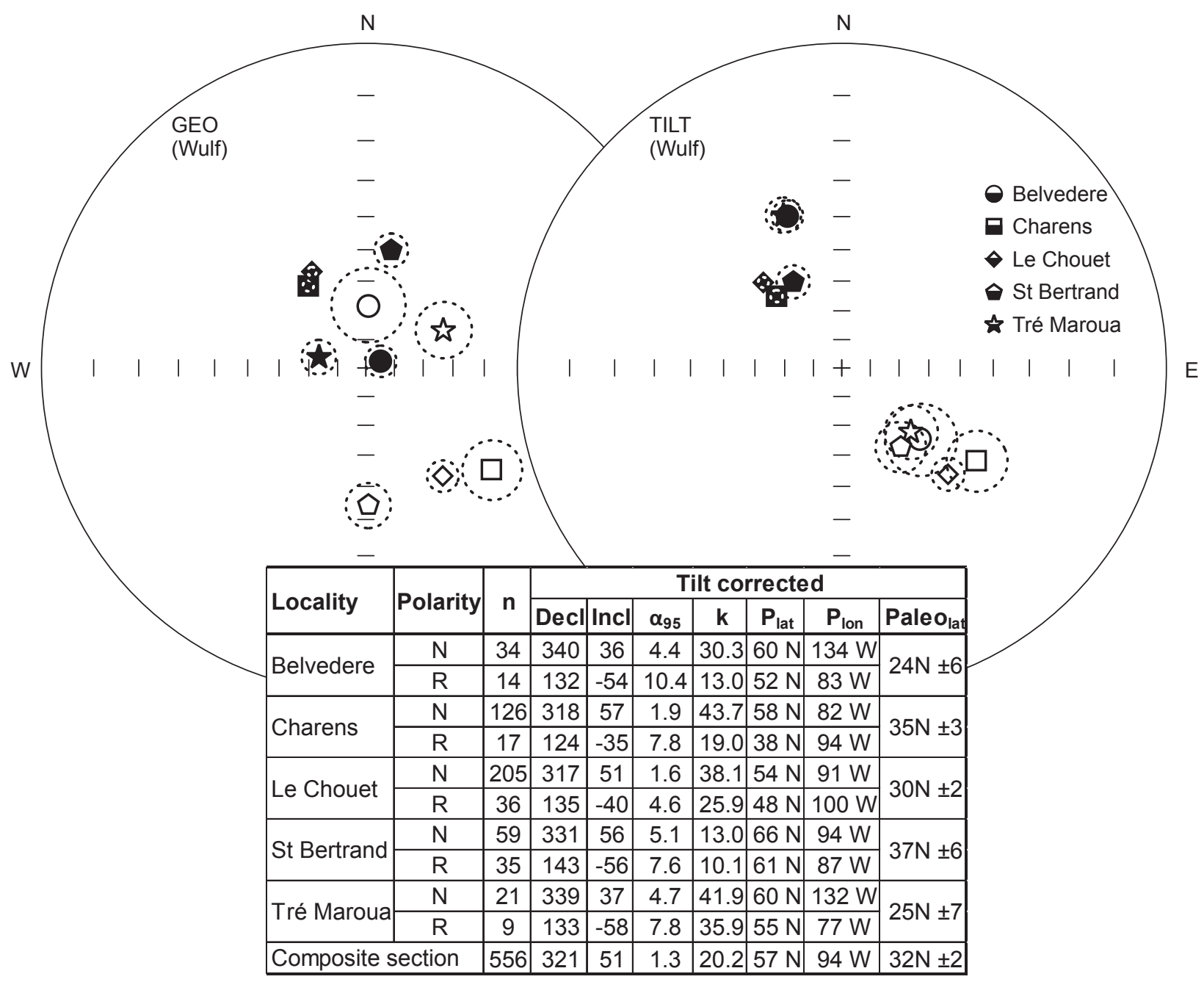

Fig. 15. The mean directions of characteristic remanent magnetization (ChRM) components in the Vocontian composite section

Wulf stereographic projection in geological and tilt corrected coordinates. Mean directions, with confidence circles at the 95\% probability level (dashed lines), are displayed for each locality as filled or empty symbols for normal and reverse polarity ChRM, respectively. The table with tilt-corrected data.

$\mathrm{N}$ - normal polarity; $\mathrm{R}$ - reversed polarity; $\mathrm{n}$ - number of specimens; Decl - declination; Incl - inclination; $\alpha 95$ - $95 \%$ confidence limit; Plat - pole latitude; Plon - pole longitude; Palaeolat - palaeolatitude. Examples of thermal demagnetization data of specimens are presented in Figure 16 

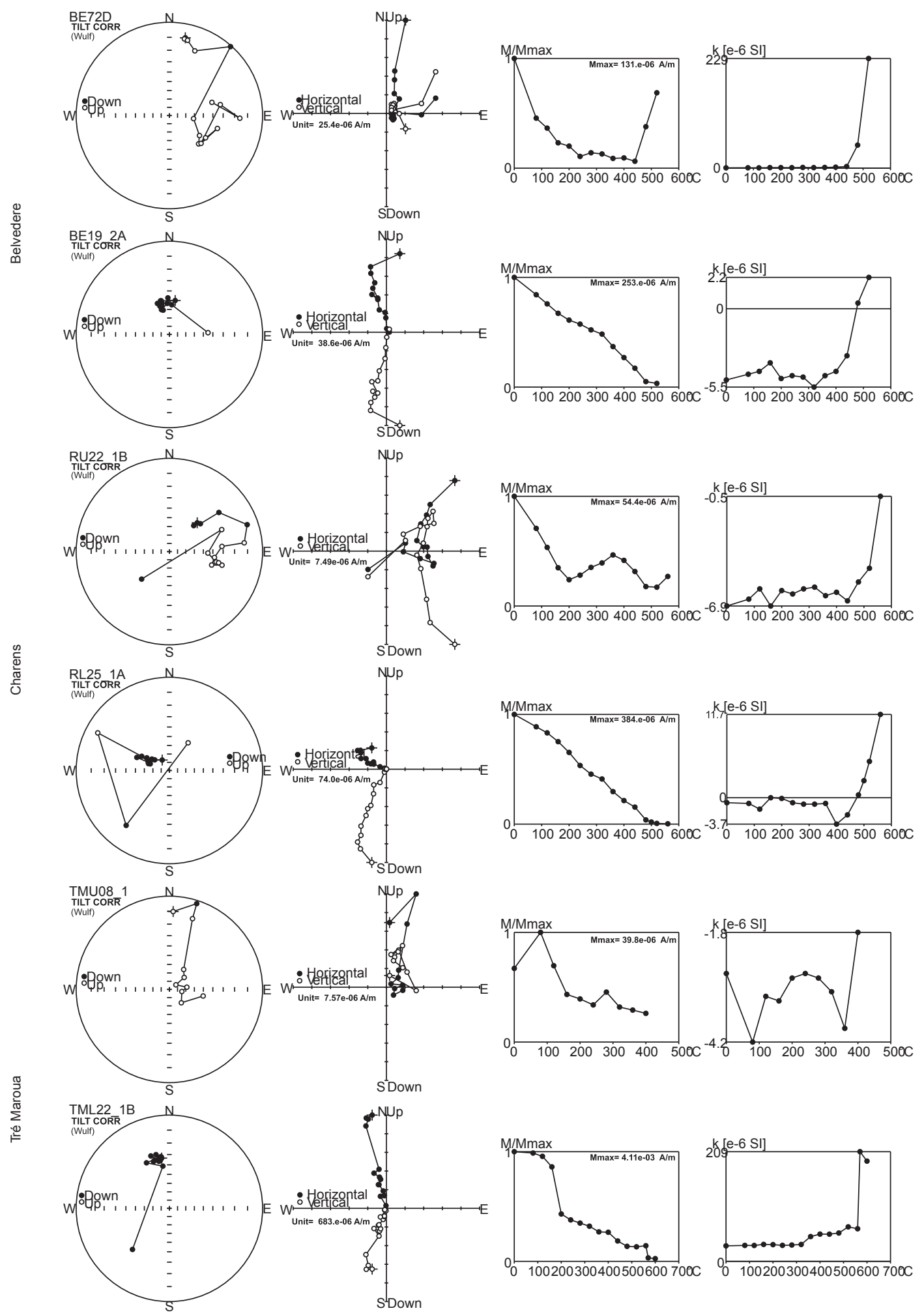

Fig. 16. Examples of demagnetization results from Belvedere, Charens and Tré Maroua.

Examples of Le Chouet and St Bertrand sections in Wimbledon et al. (2013) and Elbra et al. (2018a), respectively. Stereographic projection (left), Orthogonal (Zijderveld) vector projection (middle-left), NRM intensity decay (middle-right) and magnetic susceptibility changes during thermal treatment (right) 


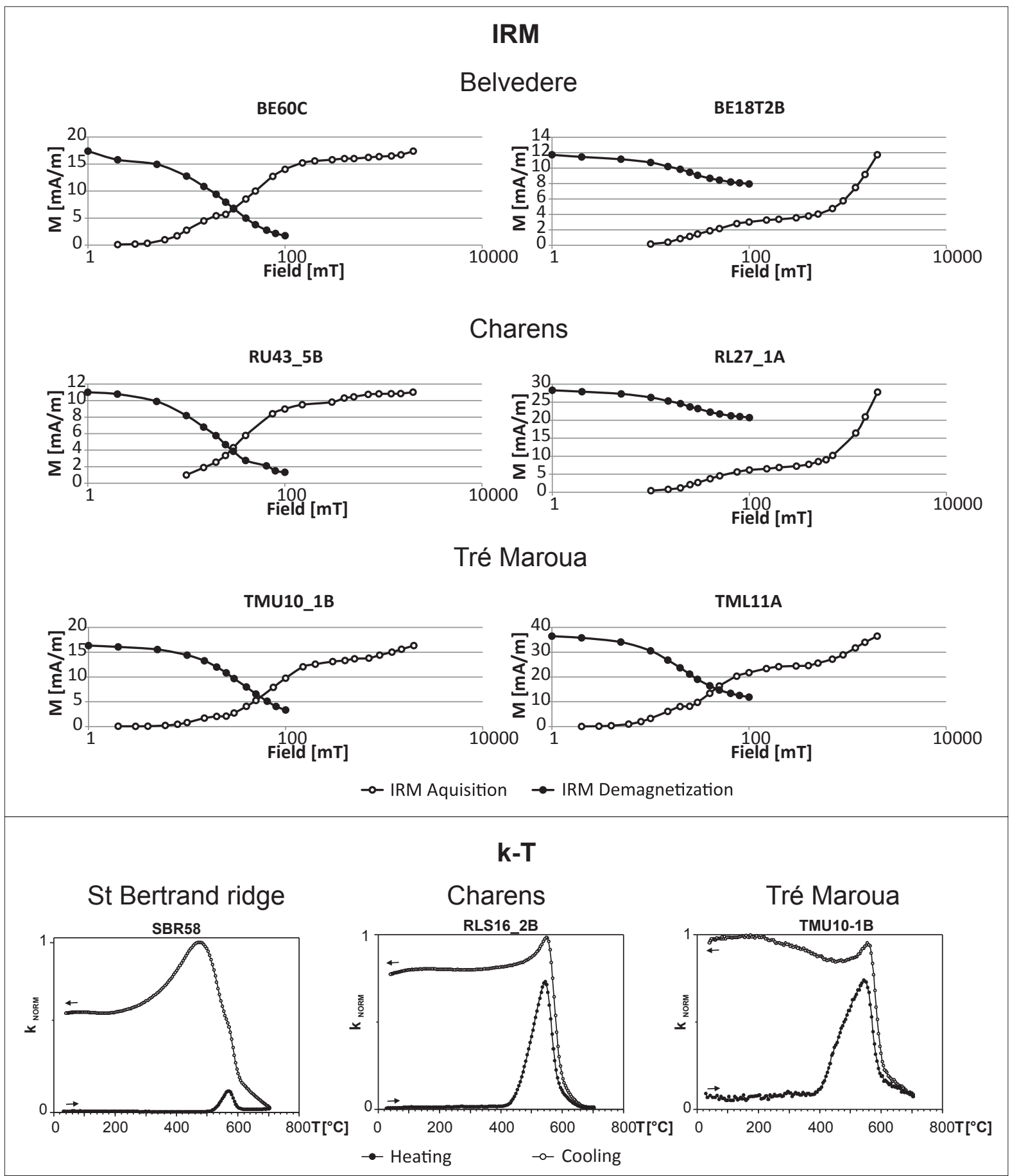

Fig. 17. Examples of isothermal remanent magnetization (IRM) and temperature dependence of magnetic susceptibility (k-T) results

A third normal zone (beds 5-8, section B), within the Remanei/Intermedia Zone, could be a continuation of M19n.2n or could belong to M20n. Likewise, the lowermost normal polarity interval (beds 1-2), within the Chitinoidella Zone, could belong to M20n or M21n.

\subsection{CARBON AND OXYGEN ISOTOPES}

In the last twenty years, Le Chouet has been the only Upper Tithonian-Lower Berriasian boundary section in the Vocontian Basin to be studied, with a detailed examination 


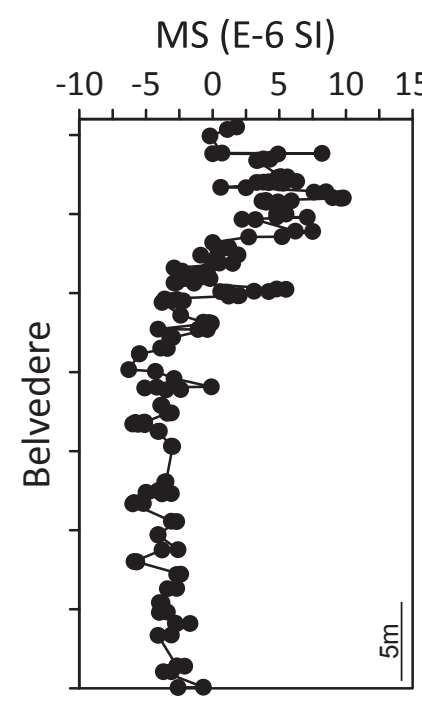

$$
\mathrm{NRM}(\mathrm{mA} \backslash \mathrm{m})
$$

$\mathrm{D}$ (deg)

I (deg)

$0.1 \quad 1 \quad 10$

$10 \quad 90 \quad 180 \quad 270 \quad 360 \quad-90$
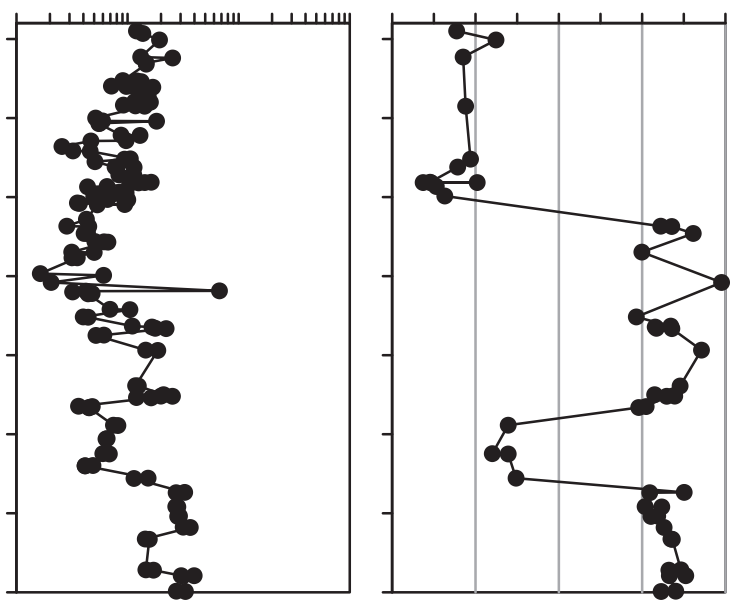

$90 \quad 0 \quad 90$
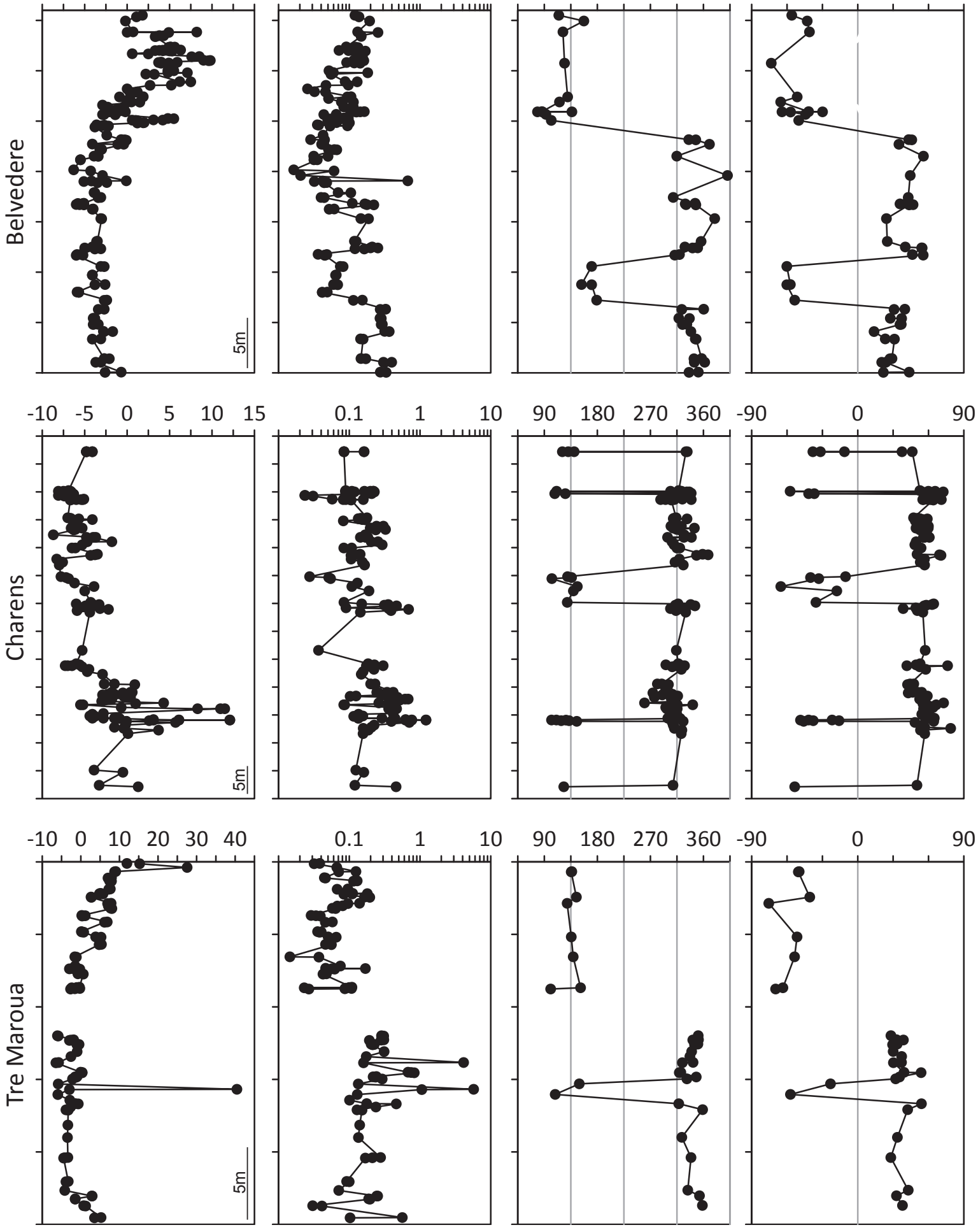

90

Fig. 18. Palaeomagnetic parameters in the Belvedere, Charens and Tré Maroua sections

Magnetic susceptibility (MS), natural remanent magnetization (NRM), palaeomagnetic declination (D) and inclination (I) of the characteristic remanent magnetization component are indicated 
of stable isotopes (Galbrun and Schnyder in Wimbledon et al., 2020a). $\delta^{13} \mathrm{C}$ values in that profile were found to range from 0.90 to $1.44 \%$ VPDB, but most of the results were between 1.02 and $1.38 \%$.

New preliminary results from Tré Maroua (Tables 1, 2; Fig. 19) show a $\delta^{13} \mathrm{C}$ curve that varies from -0.79 to $1.16 \%$ $\mathrm{V}$-PDB, with a largest negative peak that exceeds a value

Table 1 Samples from the Tré Maroua lower section (B), as shown in Figure 19

\begin{tabular}{|c|c|c|}
\hline Bed No. & $\begin{array}{c}\delta^{13} \mathrm{C} \\
(\% \circ \mathrm{V}-\mathrm{PDB})\end{array}$ & $\begin{array}{c}\delta^{18} \mathrm{O} \\
(\% \mathrm{~V} \text { V-PDB })\end{array}$ \\
\hline 2 & 0.74 & -1.34 \\
\hline $3 \mathrm{~T}$ & 1.16 & -0.79 \\
\hline 4 & 1.14 & -1.03 \\
\hline 5 & 1.09 & -1.06 \\
\hline 6 & 1.11 & -1.21 \\
\hline 7 & 0.19 & -0.28 \\
\hline 8 & 0.89 & 0.43 \\
\hline 9 & 0.96 & -1.13 \\
\hline 10 & 1.02 & -1.13 \\
\hline 12 & 0.95 & -1.19 \\
\hline $12 \mathrm{~m}$ & 0.97 & -1.98 \\
\hline 13 & 0.89 & -1.71 \\
\hline 14 & 0.69 & -1.38 \\
\hline 17 & -0.02 & -0.46 \\
\hline 21 & 0.47 & 0.18 \\
\hline 22 & -0.79 & -0.25 \\
\hline 23 & 0.17 & -0.64 \\
\hline 26 & -0.68 & -0.71 \\
\hline 27 & -0.15 & -1.01 \\
\hline 28 & 0.9 & -1.27 \\
\hline
\end{tabular}

Table 2 Samples from the Tré Maroua lower part of the upper section (A), as shown in Figure 7

\begin{tabular}{|c|c|c|}
\hline Bed No. & $\begin{array}{c}\delta^{13} \mathrm{C} \\
(\% \text { V-PDB })\end{array}$ & $\begin{array}{c}\delta^{18} \mathrm{O} \\
(\% \mathrm{~V}-\mathrm{PDB})\end{array}$ \\
\hline 17 & 0.73 & -1.13 \\
\hline 16 & 0.71 & -0.96 \\
\hline 15 & 0.71 & -0.62 \\
\hline 14 & 0.73 & -0.95 \\
\hline 13 & -0.41 & -0.5 \\
\hline 12 & 0.74 & -1.34 \\
\hline 10 & 0.83 & -1.1 \\
\hline 9 & 0.84 & -1.18 \\
\hline 8 & 0.87 & -1.14 \\
\hline 7 & 0.14 & -0.38 \\
\hline $10 \mathrm{t}$ & 0.74 & -1.34 \\
\hline
\end{tabular}

of $-0.79 \%$ V-PDB in the lowermost part of the Alpina Subzone. A decrease in $\delta^{13} \mathrm{C}$ values is observed in the lower section (right-hand column, B) from bed $17(-0.02 \%)$ to bed $27(-0.15 \%$ ) - with positive variations up to $0.47 \%$ (bed 21 ), respectively $0.17 \%$ (bed 23 ). The straightness of the $\delta^{13} \mathrm{C}$ curve from bed 8 in the lower upper section (lefthand column, $\mathrm{A})(\sim 0.7-0.8 \%$ ) fully corresponds to the pattern in the Ferasini to Elliptica subzones seen elsewhere in Tethys.

A negative shift of the $\delta^{13} \mathrm{C}$ values at around the $\mathrm{J} / \mathrm{K}$ boundary has been reported from several localities, and a significant decrease of $0.4 \%$ was recently recorded in the Lókút section (Grabowski et al., 2017), and slight negative excursions have been observed at Puerto Escaño (Žák et al., 2011), Brodno (Michalík et al., 2009), Hárskút (Főzy et al., 2010; Price et al., 2016), Frisoni (Weissert and Channell, 1989), Kurovice (Košt’ák et al., 2018), Velykyi Kamianets (Grabowski et al., 2019), and recently also from Mexico (Barragán et al., 2020). This slight decrease in the $\delta^{13} \mathrm{C}$ values at the base of the Alpina Subzone may have potential for global correlation (Košt'ák et al., 2018). We may note this shift as an important geochemical marker at about the base of the Berriasian.

The $\delta^{18} \mathrm{O}$ curve for Tré Maroua sequence shows larger excursions, varying between -1.98 to $0.43 \%$ V-PDB within the Colomi to Ferasini subzones. These variations and trends might potentially indicate climatic oscillations - i.e. slight progressive warming from the late Tithonian Chitinoidella / Remanei zonal boundary, and into the Colomi Subzone (lower section), with a decrease of values from +0.43 to $-1.98 \%$ from bed 7 to bed 12 . From bed 12 to bed 21 (uppermost Colomi Subzone to lower Alpina Subzone) an increase in $\delta^{18} \mathrm{O}$ values is observed (from -1.98 to $+0.18 \%$ ), which may reflect a slight progressive cooling, and from bed 21 (lower section) to bed 12 (upper section) $(-1.34 \%$ ), in the middle part of Ferasini Subzone, this slight negative trend might reflect a slight warming event. Stable isotope data from the $\mathrm{J} / \mathrm{K}$ transition in the Tré Maroua section show a consistent record within Tethys and the global $\delta^{13} \mathrm{C}$ stack (Michalík et al., 2009, 2016; Žák et al., 2011; Price et al., 2016; Grabowski et al., 2017; Košt’ák et al., 2018).

The limited $\delta^{13} \mathrm{C}$ curve for Tré Maroua is compared with the fuller record from Le Chouet in Figure 20.

All samples were measured 18 times in 3 sets (6 analyses per set). The first measured from each set ( 1 from 6 ) was excluded, as these had been used for initial instrument measurement calibration. Samples from beds 18, 19, 20, 24 and 25 (not shown in Figure 7) showed apparent diagenetic alteration. The $\delta^{13} \mathrm{C}$ and $\delta^{18} \mathrm{O}$ values in these samples were in direct correlation $(r>0.8)$. Measurements were repeatedly performed and this confirmed a diagenetic overprint in these samples. 

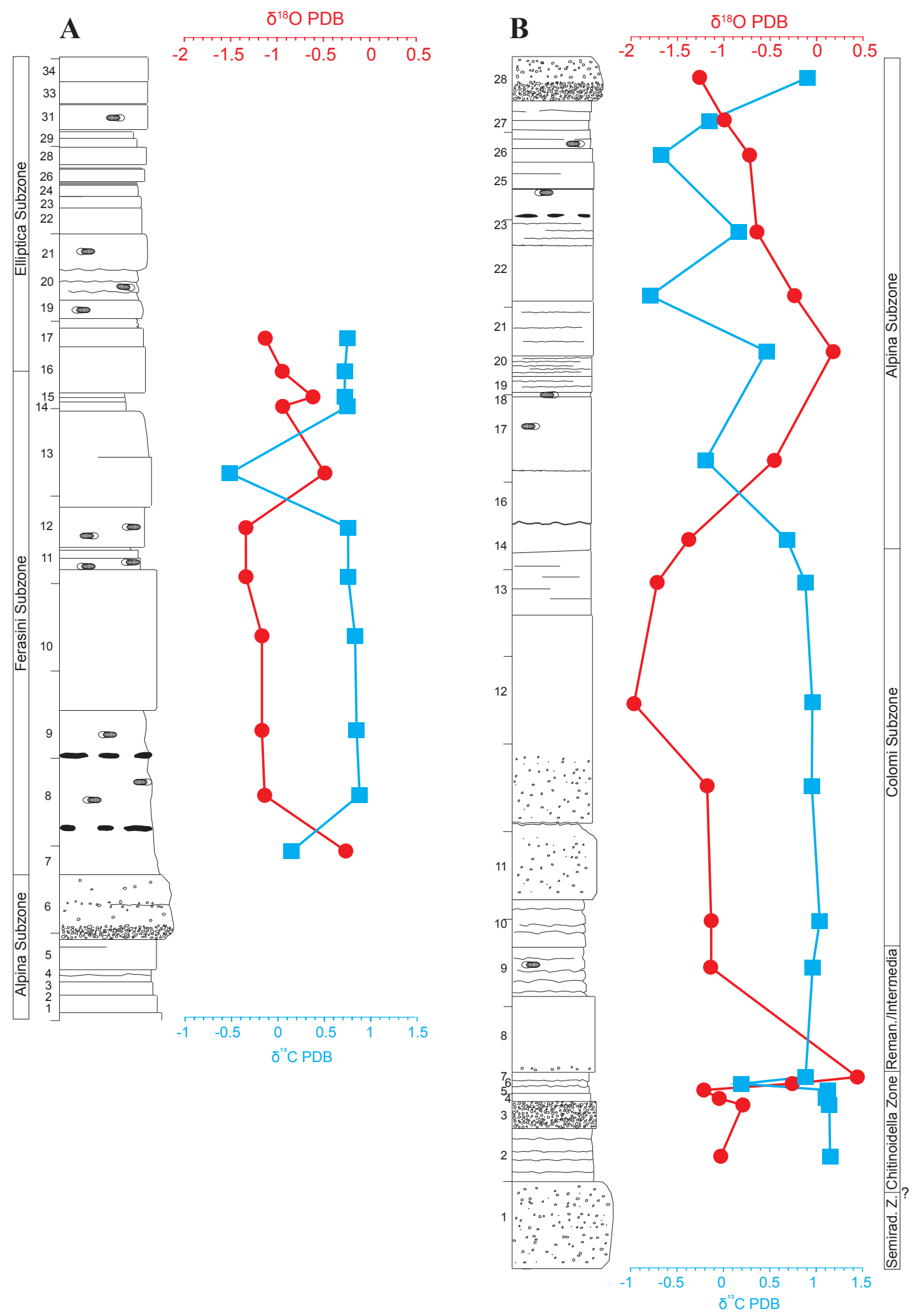

Fig. 19. Preliminary results for carbon $\left(\delta^{13} \mathrm{C}\right)$ and oxygen $\left(\delta^{13} \mathrm{C}\right)$ isotopes from Tré Maroua 


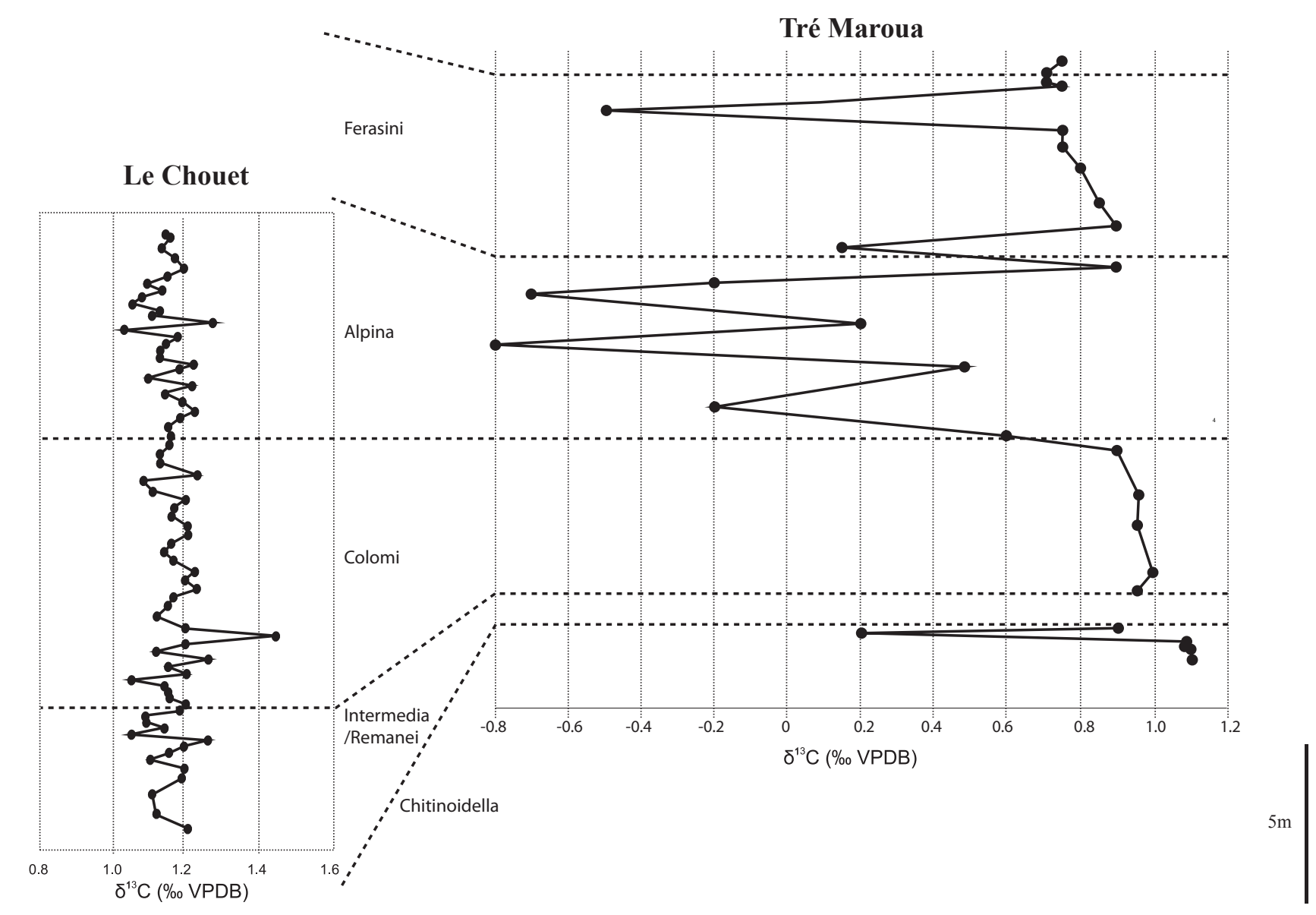

Fig. 20. A comparison of the Tré Maroua $\delta^{13} \mathrm{C}$ results with the fuller and more regular record from Le Chouet (Schnyder and Galbrun in Wimbledon et al., 2020a)

\section{IUGS REQUIREMENTS FOR A GSSP AND THEIR FULFILMENT}

Following the IUGS Guidelines (Remane et al., 1996), we have examined sites with the best correlation potential in our search for the most suitable GSSP locality. Our thinking in selecting the better candidate that we propose has already been outlined in Part 1. There we describe short-listing and a final selection, founded on integration of data from different facies and palaeogeographic provinces, all combined in a global synthesis.

We are able to state the following concerning the suitability of Tré Maroua, paraphrasing the detailed requirements for a GSSP, as laid out by Remane et al. (1996), and applying them to the site.

The proposed stratotype-section contains the best possible record of the relevant marker events:
- There is extensive exposure over an adequate thickness of sediments, guaranteeing that a sufficient time interval is represented by the section.

- The boundary can also be determined by interpolation, using auxiliary markers at and close to the boundary.

- There is no gap and no condensation in proximity to the boundary level.

- The rate of sedimentation was sufficient that successive key events can be easily separated.

- There is an absence of significant synsedimentary and tectonic disturbances.

- There is an absence of metamorphism and strong diagenetic alteration.

- There is an absence of vertical or lateral litho- and biofacies changes at and close to the boundary.

- The facies present are most favourable for long-range biostratigraphic correlations; corresponding to an open marine environment. 
- There is an abundance and diversity of well-preserved fossils throughout the critical interval - including the fossil groups most indicative of relative age.

- Biotas present offer the best possibility for precise correlations over the widest geographical area, markers being duplicatable on all continents.

- Magnetostratigraphy (calibrated with biostratigraphic markers) is integral to the positioning of the boundary level and the selection of the GSSP.

- Though no radiometric dating is possible at the GSSP (in common with most $\mathrm{J} / \mathrm{K}$ sections), there is dating available precisely at the primary marker level at other localities.

The mechanism for the selection of the primary marker and the choice of a GSSP section by the Working Group have been described in Part 1. To reiterate, in June 2016, the then 70-plus Berriasian Working Group held a formal vote to select the primary marker for the Tithonian/Berriasian boundary. With a $76 \%$ majority, the base of the Calpionella alpina Subzone was selected (votes cast - "Yes" 57: "No" 16: Abst. 2). Next, a shortlist of potential GSSP sites was considered at the WG's workshop at Kroměříz in 2018, and a choice was then made between profiles in the Vocontian Basin and Fiume Bosso in the Italian Apennines. In May 2019 , this was formalised and the Berriasian group completed a consultation and a one-month vote on the selection of a GSSP locality. The group voted with a $73 \%$ majority to select Tré Maroua in the Vocontian Basin (votes cast - Tré Maroua 38; Fiume Bosso 9: Abst. 5).

\section{ACCESS TO AND CONSERVATION OF THE GSSP SITE}

The locality lies in the most north-easterly corner of the Parc régional des Baronnies provençales, and more specifically within the Lac du Peyssier protected area. A small, sometimes single track, country road (D249T) lies 100 metres to the east. Access to the Tré Maroua GSSP locality is only possible on foot via rough paths and by wading two stream courses, the Torrent de Maraizes and the Torrent de Tré Maroua, which are subject to seasonal flooding. The terrain of the geological site comprises cliffs, and steep and rocky slopes, which make the area unsuitable for forestry or farming, and it could only ever be used for rough grazing. Therefore, threats from any kind of rural use or urbanising development, in what is public open space, are essentially non-existent.

Dr Bruno Galbrun, President of the Stratigraphy Section of the Société Géologique de France, contacted the mayor of Le Saix last October, wrote at length on the topic of GSSPs and their protection, and initiated discussion of conservation and pedagogical possibilities at the site.

It is important to note that the Tré Maroua site and surrounding hills and woodland belong to the commune of Le Saix. The Mayor of Le Saix has informed the authorities of the Hautes-Alpes Department of the stratigraphic interest and importance of Tré Maroua.

\section{CONCLUSIONS}

The Tré Maroua section (Le Saix, Hautes-Alpes, France) is proposed as the Global Boundary Stratotype Section and Point (GSSP) for the Berriasian Stage. Its very well and extensively exposed outcrops make up part of a thick Tithonian to Upper Cretaceous sequence. The boundary interval was characterised by continuous sedimentation (minimally for 600,000 years both below and above the boundary), with no significant facies change, tectonic disturbance, or remagnetisation.

The locality has been documented together with five Vocontian Basin localities that also expose the boundary succession, so as to test variations in facies, biota, and magnetic properties - all with the aim of gaining a better understanding of the stratigraphy. The Tré Maroua profile shows the best development of the boundary interval in this muchstudied type area for the Berriasian. In keeping with statements made in earlier GSSP proposals for other stages, we can state that no other documented site, or similarly widespread and viable alternative biostratigraphic marker, has been proposed to the Berriasian WG. It is perhaps worth remembering that the primary marker for the Berriasian Stage base (Alpina Subzone), even disregarding secondary nannofossil markers that can be employed as substitutes, has a much wider geographical extent than markers used for the stages immediately below and above (Tithonian - Hybonotum Zone base: Valanginian - Pertransiens or Darderi zones).

In a historical context, boundary definition in recent generations has been stable. The commencement of Berriasian Working Group activity came at a time when there was a realisation that putative ammonite boundaries were not well enough defined (e.g. Grandis Subzone), or had complications with systematics and vertical distribution (e.g. Jacobi Subzone) or limited geographical extents (e.g. Subalpina Subzone). Our final choice of both a primary marker and the stage base reflects predominant usage since the 1990s, as older, less effective, methods of correlation (and less useful biota) were replaced with much more accurate (and thus more favoured) biotic indicators, coupled with ever-improving magnetostratigraphic calibration (see Part 1). The selected boundary level and the boundary marker now in use (calpionellid Alpina Subzone) still fall within the traditional 
interval (in the Jacobi Zone of authors). The Alpina Subzone base has in recent decades become acknowledged as the most correlatable level in the boundary interval.

The Tré Maroua locality yields typical macrofossils (mainly ammonites) and microfossils, which are abundant and well preserved, in the context of magnetozones M20nM17r. The base of the Berriasian Stage is defined by the base of the Alpina Subzone (the base of the Calpionella Zone), and the appearance of small, orbicular Calpionella alpina in bed 14 (lower section). One very short magnetic subzone, M19n.1r, occurs just above the base of the calpionellid Alpina Subzone: it was long ago identified (Ogg, Lowrie, 1986) as "a readily identifiable fingerprint pattern" in the boundary interval.

Bracketing the base of the Alpina Subzone, other events (calpionellid, nannofossil, ammonite and magnetic - Fig. 21, 22 ) in the calpionellid Colomi-Ferasini subzones are of inter-regional significance. The choice of these several markers is promoted by their wide distribution in North and South America, Africa and Eurasia (see Part 1).

These correlatable datums are as follows, in ascending stratigraphic sequence.

\section{Markers defining the boundary at Tré Maroua}

In the Colomi-Ferasini zonal interval markers are:

FOs of Crassicollaria colomi and Tintinopsella carpathica in bed 10 (lower section);

FO Nannoconus globulus minor in mid bed 12 (lower section);

FO of Crassicollaria brevis in bed 13 (lower section);

FO of Nannoconus wintereri in bed 13 (lower section);

Alpina Subzone base, bed 14 (lower section) - Primary marker for the Berriasian Stage base;

FOs Nannoconus steinmannii minor and Nannoconus wintereri in mid bed 16 (lower section);

M19n.1r in upper bed 17 (lower section);

FO of Delphinella gr. delphinense in bed 17 (lower section);

FO of Nannoconus globulus globulus in bed 18 (lower section);

FO of Nannoconus kamptneri minor in bed 5 (upper section - equivalent to bed 27 lower section);

Base of M18r in bed 6 (upper section);

FO of Remaniella catalanoi in bed 7 (upper section);

FO of Remaniella ferasini in bed 8 (upper section);

FO of Nannoconus steinmannii steinmannii in bed 9 (upper section);

FO of Nannoconus kamptneri kamptneri in bed 11 (upper section).
As discussed in chapters in Part 1, in a wider geographical setting and for the purposes of inter-regional correlation, a number of markers stand out as valuable in approximating the basal Berriasian boundary and the immediate boundary interval. These are summarised in Figure 23

Correlatable secondary markers coinciding with the Primary Marker

- Nannoconus steinmannii minor FO coincides with the base of the Alpina Subzone.

- Nannoconus wintereri FO is a marker for mid M19n.2n (from just below to just above the base of the Alpina Subzone).

- Hexalithus strictus FO is a marker for mid M19n.2n (from just below to just above the base the Alpina Subzone).

Correlatable secondary markers bracketing the Primary Marker

- Cruciellipsis cuvillieri FO is a marker for lower M19n.2n (just below to the base of the Alpina Subzone).

- Nannoconus globulus globulus FO is a marker for lower M19n.2n (just below to the base of the Alpina Subzone).

- FOs of Cretarhabdus octofenestratus, Nannoconus kamptneri minor, N. kamptneri kamptneri, and N. steinmannii steinmannii appear in M19n.1r-M19n.1n, equating to the top of the Alpina Subzone.

- The widespread ammonite genus Delphinella has an FO that approximates the level of the Alpina Subzone's base (in mid M19n.2n).

- The short reversed magnetosubzone M19n.1r comes close above the base of the Alpina Subzone. In sections where it cannot be detected, then the base of M18r is next in succession above that.

- The base of radiolarian "Unitary Zone" 14 (marker species listed in the Radiolaria chapter, Part 1) occurs close above the base of the Calpionella Zone (Alpina Subzone).

- The LAD of the organic-walled dinoflagellate cyst Senoniasphaera jurassica approximates the base of the Berriasian (see Part 1, Palynology chapter).

Markers in the immediate vicinity of the boundary at Tré Maroua are indicated on a photograph of the outcrop (Fig. 10), in Part 1, fig. 3, and herein in Figs 21 and 22 these are shown in a matrix of stratigraphically useful datums, that are useful for inter-regional correlation in the M19r to M18r interval. Figures 21 and 22 are the latest iterations in a series of correlation charts that have (with growing data) been used in WG workshops and publications, which have undergone numerous updates since first published in 2011 and 2013. The figures show correlation of magnetozones, biozones and biostratigraphic markers at various classical $\mathrm{J} / \mathrm{K}$ boundary localities, inside the Berriasian Vocontian Basin type area and outside: Theodosia (Ukraine), Rio Argos (Spain), Fiume Bosso (Italy), Brodno (Slovakia), Puerto Es- 


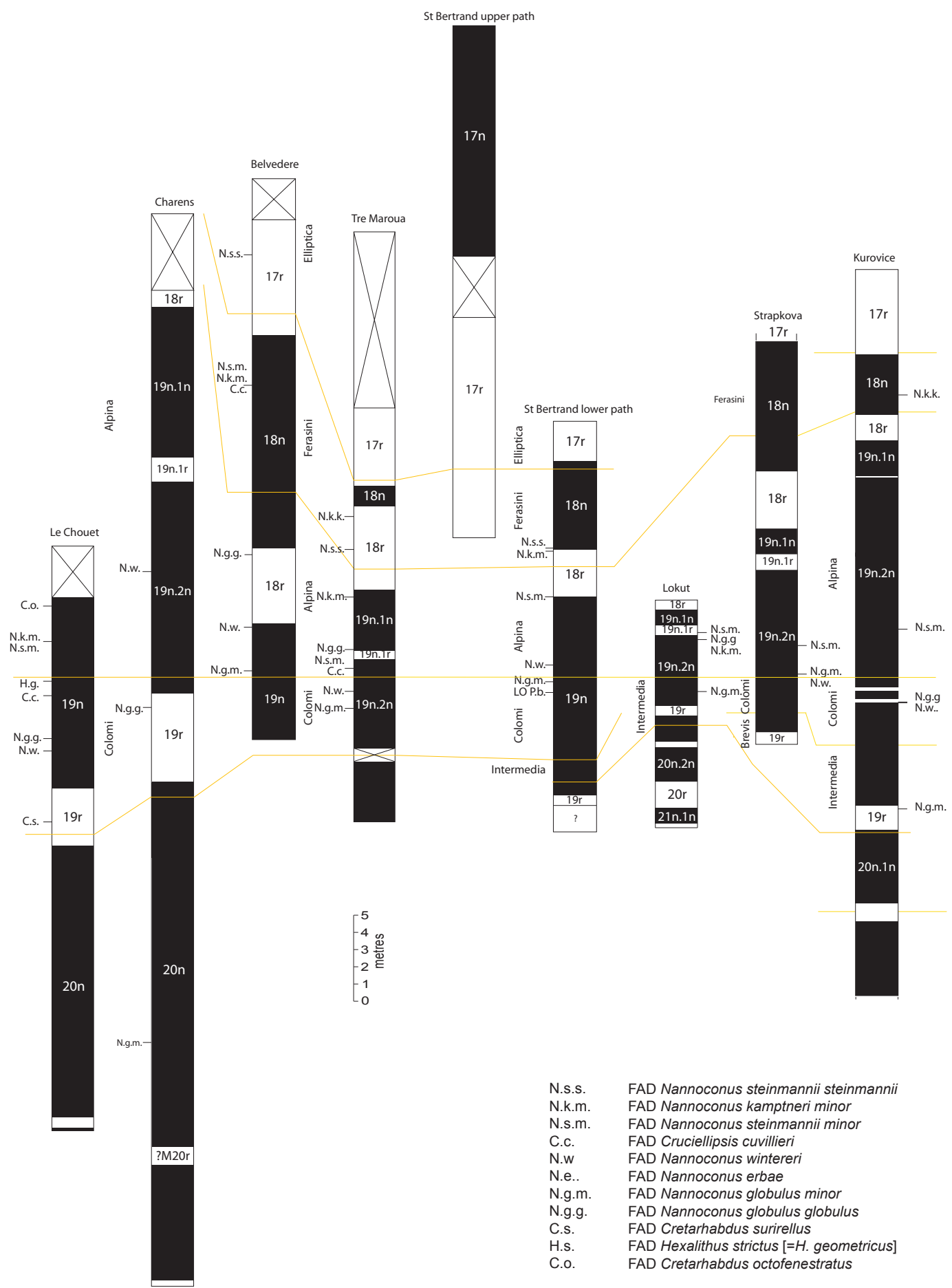

Fig. 21. Correlations between Tré Maroua and other Vocontian basin localities and other further $\mathrm{J} / \mathrm{K}$ sites considered in discussion of GSSP contenders

Figures 21 and 22 are derived from the following sources: Vocontian Basin sites (Tré Maroua, Charens, Le Font de Saint Bertrand, Belvedere and Le Chouet, France) Wimbledon et al., 2020a; Theodosia (Ukraine) Bakhmutov et al., 2018; Velykyi Kamianets (Ukraine) Grabowski et al., 2019; Rio Argos (Spain) Hoedemaeker et al., 2016; Fiume Bosso (Italy) Houša et al., 2004, and unpublished; Brodno (Slovakia) Houša et al., 1999, Michalík et al., 2009; Puerto Escańo (Spain) Pruner et al., 2010; Kurovice (Czech Republic) Svobodová et al., 2019; Torre de' Busi (Italy) Channell et al., 2010, Casellato, 2010; Lokut (Hungary) Grabowski et al., 2010; Nutzhof (Austria) Lukeneder et al., 2010; Strapkova (Slovakia) Michalík et al., 2016; Kopanitsa (Bulgaria) Stoykova et al., 2018; Nordvik (Russia) Schnabl et al., 2015 


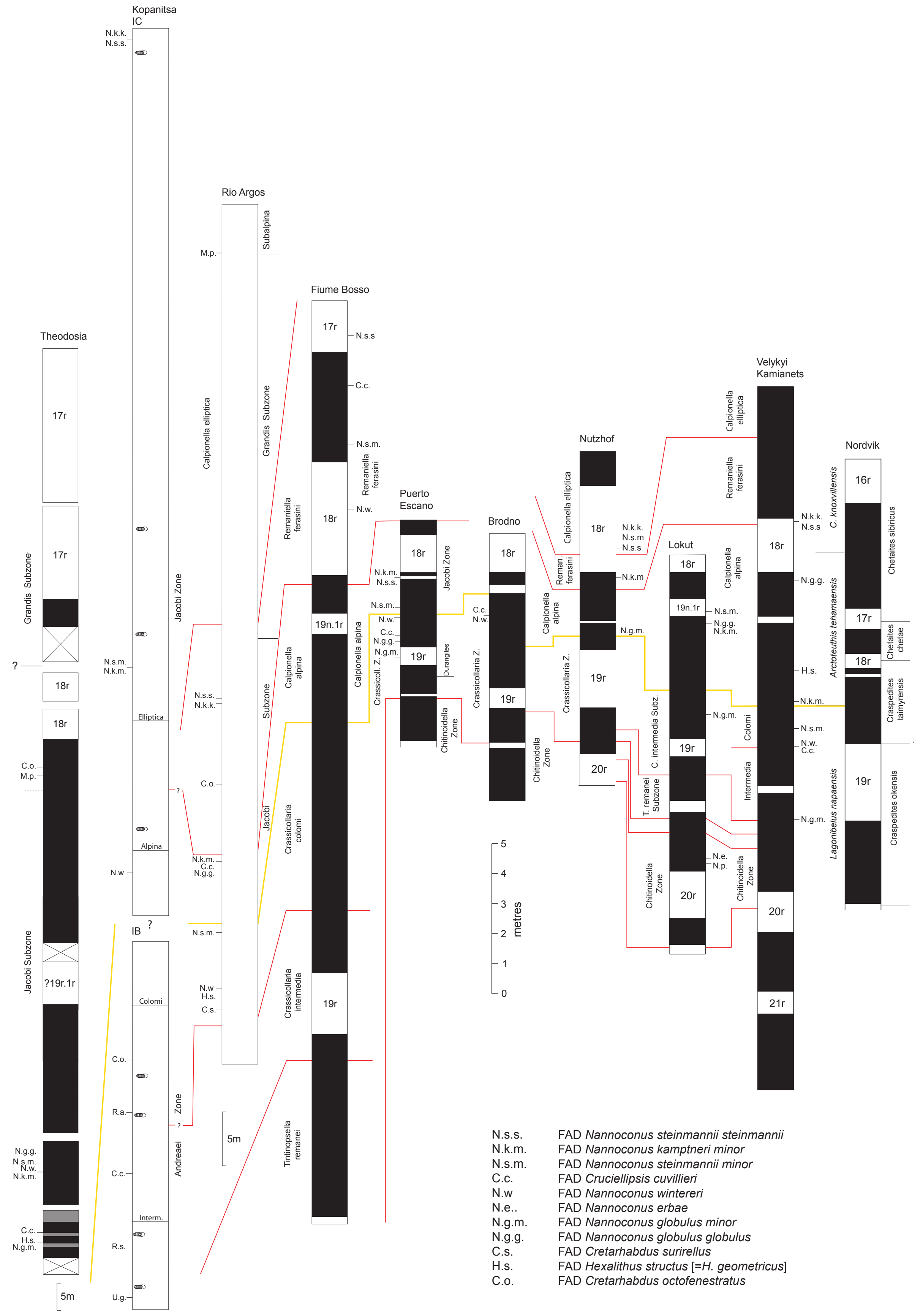


caño (Spain), Kurovice (Czech Republic), Torre de' Busi (Italy), Lokut (Hungary) and Nutzhof (Austria), with, additionally, Strapkova (Slovakia), Kopanitsa (Bulgaria) and Velykyi Kamianets (Ukraine). The characteristic pattern of markers proven at Tré Maroua and other Calcaires Blancs localities in the Vocontian Basin (Charens, Le Font de Saint Bertrand, Belvedere and Le Chouet) may be compared with and related to that seen at these other sites. These were the particular localities proposed, discussed and considered as contender GSSPs at the Kroměříž meeting, and were then the subject of further consultations.

At Tré Maroua, the calcareous nannofossil event that best approximates the base of the Alpina Subzone and the Tithonian/Berriasian boundary is the FO of Nannoconus steinmannii minor: it is a nannofossil taxon with considerable correlative value, notably in regions without calpionellids.

Part 1 of this proposal discussed the possibilities for the selection of a GSSP for the Berriasian Stage of the Cretaceous System, based on available practical methods for correlation in the traditionally defined Tithonian/Berriasian interval. This second part has laid out the stratigraphic evidence justifying the proposal of the locality of Tré Maroua (Hautes-Alpes, SE France) (Fig. 24) as the GSSP, within the historical $\mathrm{J} / \mathrm{K}$ boundary interval. This is at a level just below the distinctive reversed magnetic subzone M19n.1r (the socalled Brodno reversal). Particularly significant for correlation are the primary basal Berriasian marker, the base of the Alpina Subzone (marked by dominance of small Calpionel- la alpina, accompanied by very rare Crassicollaria parvula and Tintinopsella carpathica), and secondary markers which bracket the base of the Calpionella Zone, the FOs of the calcareous nannofossil species Nannoconus wintereri (just below the Alpina boundary) and the FO of Nannoconus steinmannii minor (just above).

The calpionellid succession which makes it possible to fix the base of the Berriasian (the Alpina Subzone) has been applied throughout western Tethys (Iberia to Black Sea) where there are any substantial documented outcrops, then extending to southern Arabia on the south and Iran on the north, westwards through the middle Atlantic to the Caribbean, to Mexico and onward to the Andes (Part 1, p. 61). Recently finds (calpionellid and nannofossil) have even been made in the sub-boreal Portland-Purbeck succession of Dorset. To this may be added the often overlapping and even wider distributions of calcareous nannofossils and dinocysts (e.g., Atlantic, North Africa, Canada, South America, Japan, Antarctic, California, Tibet, Australian shelf, Arctic). The widespread application of 'Tethyan' calpionellids in Mexico, supplanting purely regional ammonite biozonations, (López-Martínez et al., 2013b, 2015a, b) and the Andes (there with nannofossils in parallel, and the first recorded magnetostratigraphy) (Riccardi, 2015; López-Martínez et al., 2017; Iglesia Llanos et al., 2017) are, in this J/K context, the greatest achievements in the Americas in recent years. They mean that, for the first time, a 'Tethyan' pattern of fossil markers (primary and supporting) approaches becoming a global pattern.

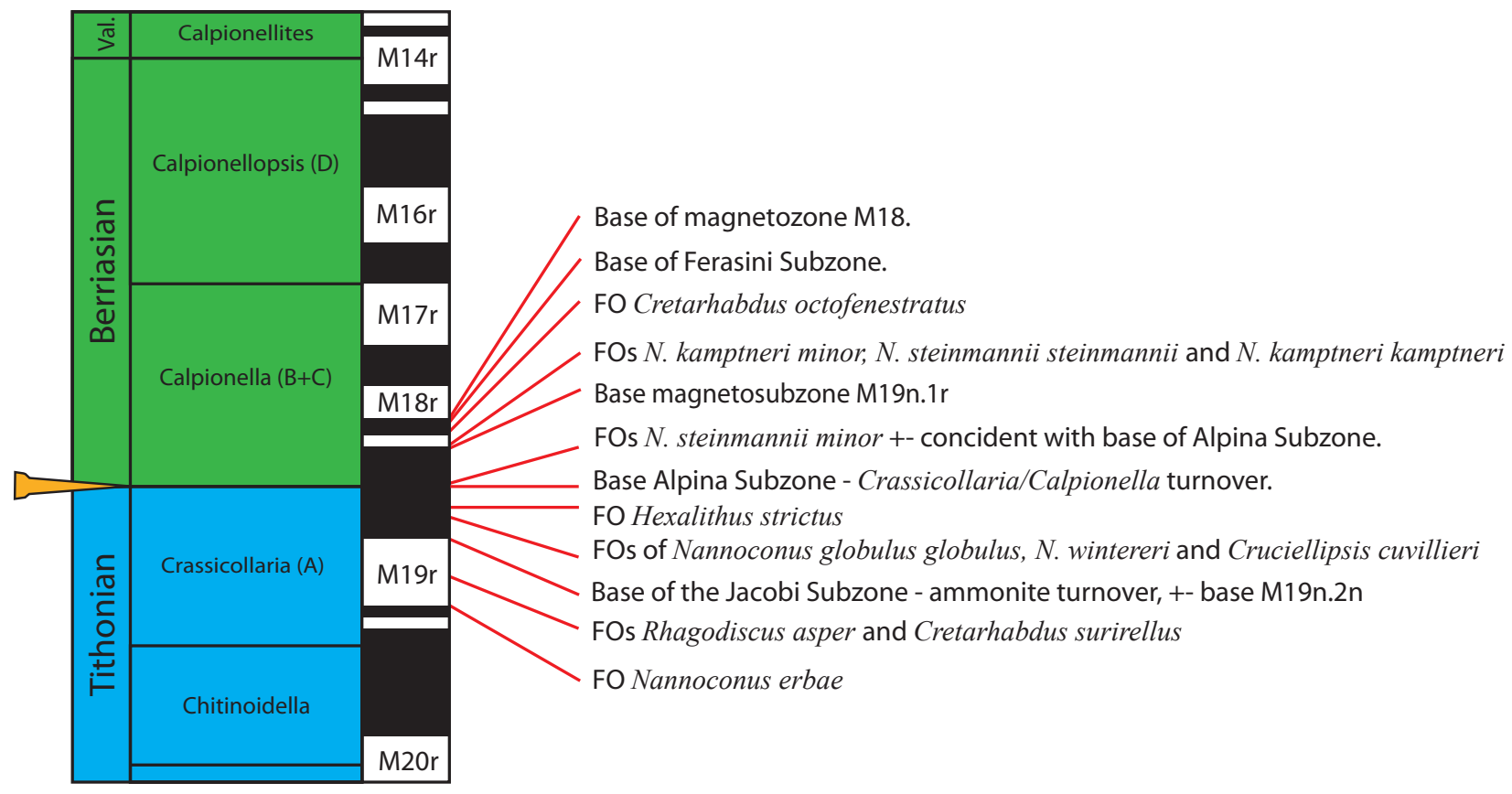

Fig. 23. Key markers (including nannofossil FOs), in sequence, in M19r and M19n 


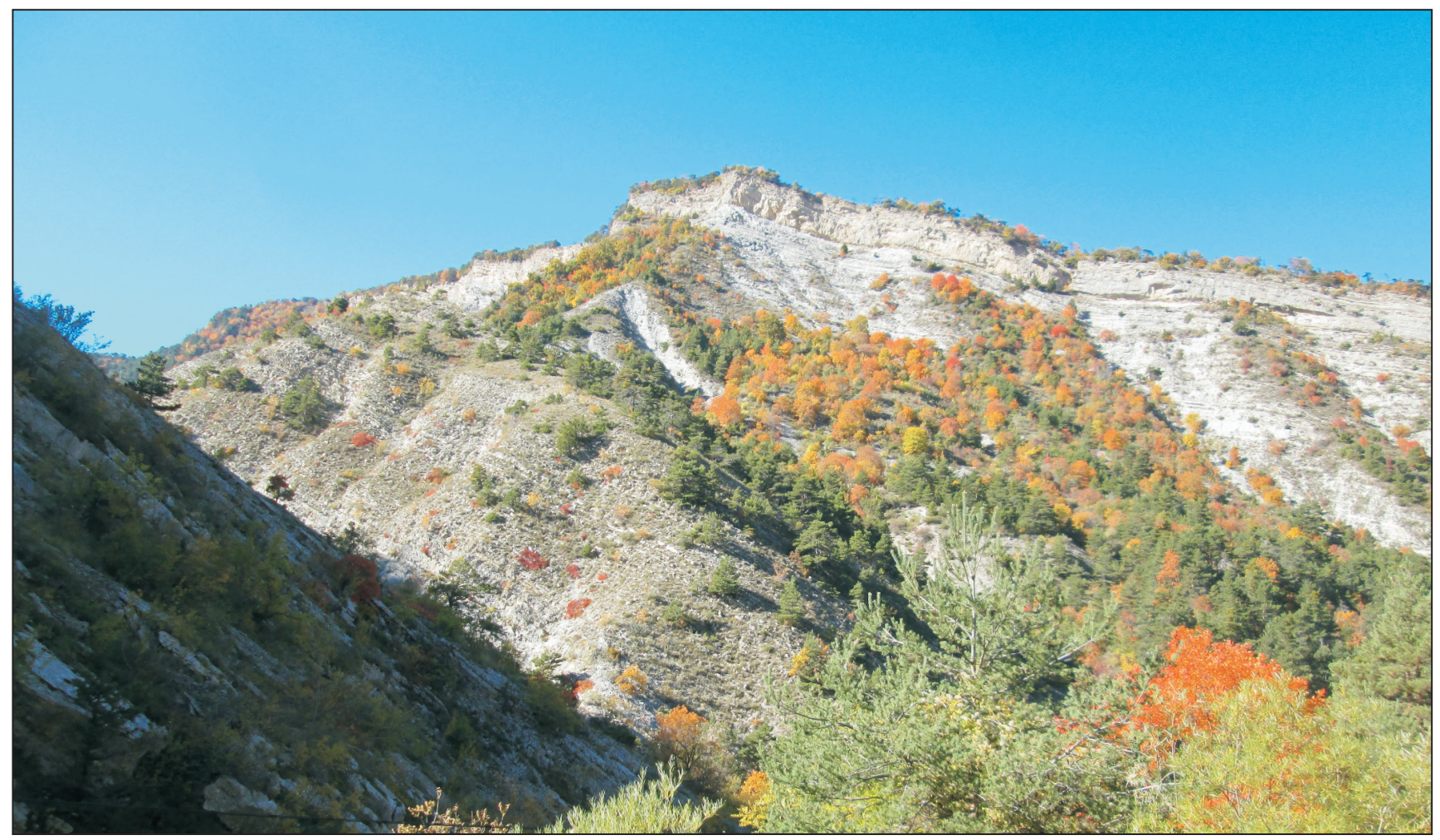

Fig. 24. General view of the Tré Maroua hillside. Cliff on the left, in shadow, is Tithonian. The uppermost Tithonian and Berriasian form the rough, forty-five degree slope above the stream course of Tré Maroua. Trees growing on the ledge above that slope are on Valanginian

A suite of calcareous nannofossils provide effective proxy markers for the base of the Berriasian. Particularly key are Nannoconus steinmannii minor and $N$. wintereri, which stand as direct indicators of the base of the Alpina Subzone, and have been recorded in all continents (e.g., Andes, Mexico, Caribbean, North Africa, Iraq, Tibet, and Europe). Hexalithus strictus FO is a marker for a short interval in mid M19n.2n, but thus far it has only a western Tethyan extent. Further widespread nannofossils bracket the base of the Alpina Zone and the boundary, one group having their FOs in lower M19n (Cruciellipsis cuvillieri and Nannoconus globulus globulus) and another in the upper Alpina Subzone, upper M19n (Cretarhabdus octofenestratus, N. kamptneri minor, N. kamptneri kamptneri, and N. steinmannii steinmannii).

The formerly used western Tethyan base of the Jacobi Subzone (Colloquium, 1975) still provides a useful level for correlation (at the base of M19n.2n), and it will have greater use when the defining ammonite faunas are fully revised. Though the zonal index Strambergella jacobi has been shown not to occur at the base of the Berriasian (sensu Jacobi Zone, nor does it coincide with a calpionellid zone to define the stage base), other ammonites are still useful for recognising this level. Further work is required on the geographical extent of the ammonite genus Delphinella, which in Mediterranean Tethys is a close proxy for the appearance of small, orbicular Calpionella alpina, and has been recorded as far afield as Japan.

Among inorganic boundary markers, magnetostratigraphy is most useful. The pattern of magnetozones in the $\mathrm{J} / \mathrm{K}$ interval has always been recognised as distinctive. The very short, reversed magnetic subzone of M19n.1r occurs $1.3 \mathrm{~m}$ above the base of the Alpina Subzone, in bed 17, both in the context of M19n. M19n has been recorded in all continents, and M19n.1r commonly, with potential to be a global marker (Figs 21, 22). Through the expanding application of magnetostratigraphy to new regions, its identification will provide a distinctive datum that may be used to extend boundary identification independently of biostratigraphy.

Notable other proxies for the boundary are: (1) the base of the belemnite Arctoteuthis tehamaensis Zone; (2) the precisely dated base of the Alpina Subzone in the Vaca Muerta Formation (Argentina) at $140.22 \pm 0.14 \mathrm{Ma}$, which gives an exact age estimate for the system boundary (Lena et al., 
2019); and (3) the base of radiolarian "unitary zone" 14 (Baumgartner et al., 1995), which is situated just above the base of the Alpina Subzone (Part 1, fig. 5).

The characterisation of the base of the Berriasian remains most difficult in the Arctic. Correlative possibilities are limited: the sparse (or absent), often endemic, ammonites and long-ranging Buchia are discussed in Part 1, as is the interpretation of magnetostratigraphy in Siberia (Schnabl et al., 2015). The belemnite Arctoteuthis tehamaensis first occurs in mid M19n.2n, in Siberia, the most distant region from Tethys. The first occurrence of this wide-ranging taxon, with a geographical extent (so far) in western USA, Japan and Arctic Russia, provides the best boundary proxy in the Arctic and in sub-boreal Panthallassa (Dzyuba, 2012; Haggart, Matsukawa, 2019). A. tehamaensis in the middle of M19n at Nordvik (Fig. 22) for instance, is a close match for the base of the Alpina Zone. In Siberia, this is a little above the base of the ammonite Taimyrensis Zone (= Nodiger Zone, Russian platform), which constitutes a less securely positioned proxy. The exact equivalence of the base of the Tehamaensis Zone to that of the Simnobelus compactus Zone in Western Siberia (Dzyuba, 2013) suggests correlations over a wider area in Russia.

The traditional core area for Tithonian-Berrasian studies between the Mediterranean and Black Sea regions, concentrating mostly on ammonites, has been expanded enormously by research in the last ten years. The fragmented correlative picture of earlier times, constrained by the biostratigraphic use of endemic biotic elements, has changed significantly: now the correlative scheme is a much more unified one (Part 1, fig. 5). This has become possible through the application, singly and collectively, of a suite of markers (magnetostratigraphy, calpionellids, nannofossils, ammonites, calcareous dinocysts, radiolaria, belemnites...) (see Part 1). Where calpionellid and ammonite finds have not allowed precise biozonations (an example is Crimea), a refined scheme of nannofossils datums has often been substituted. It is likely (with intensive and accurate sampling) that nannofossils will become more important in expanding and refining $\mathrm{J} / \mathrm{K}$ correlations in new regions. We can hope also that the most remote areas with calpionellids (Tibet, New Guinea and Timor) will eventually also be properly explored and documented.

Finally, after generations of extrapolations and estimates, a radiometric date has at last been obtained from a Berriasian profile that yields reliable biostratigraphic markers. A date of $140.22 \pm 0.14 \mathrm{Ma}$ obtained for the base of the Alpina Subzone (at Las Loicas) gives an accurate age estimate for the stage/system boundary as here defined (see Part 1, Geochronology).
Acknowledgements. We sincerely thank and acknowledge all the help, discussions, data and comradeship of our many fellow members of the Berriasian Working Group.

It is a pleasure to thank Dr. Jakub Trubač for his measurement of isotopes from Tré Maroua (Institute of Geochemistry, Mineralogy and Mineral Resources, Charles University, Prague). We acknowledge Martin Košták, who made valuable contributions to this work. Daniela Reháková was supported by the VEGA 2/2013/20 Project. Andrea Svobodová acknowledges support from project GAČR 20$10035 \mathrm{~S}$ and institutional funding from RVO 67985831. The Czech palaeomagnetic team was financed by project GA CR 20-10035 S and co-financed by institutional funding from RVO 67985831.

We heartily thank Dr. Andrzej Wierzbowski and Dr. Jozef Michalik for their helpful reviews of the typescript.

We dedicate this publication to our dear friend Platon Tchoumatchenco, who contributed to the activity of the Berriasian Working Group for ten years, participated in all votes to select markers and the GSSP site, but, sadly, died before we came, finally, to making this proposal.

\section{REFERENCES}

AGUIRRE-URRETA B., LESCANO M., SCHMITZ M.D., TUNIK M., CONCHEYRO A., RAWSON P.F., RAMO V.A., 2015 - Filling the gap: new precise Early Cretaceous radioisotopic ages from the Andes. Geological Magazine, 152: 557-564.

AGUIRRE-URRETA B., SCHMITZ M., LESCANO M., TUNIK M., RAWSON P.F., CONCHEYRO A., BUHLER M., RAMOS V.A., 2017 - A high precision $\mathrm{U}-\mathrm{Pb}$ radioisotopic age for the Agrio Formation, Neuquén Basin, Argentina: Implications for the chronology of the Hauterivian Stage. Cretaceous Research, 75: 193-204.

AGUIRRE-URRETA B., NAIPAUER M., LESCANO M., RAMOS V.A., 2019 - The Tithonian chrono-biostratigraphy of the Neuquén Basin and related Andean areas: A review and update. Journal of South American Earth Sciences, 92: 350-367.

ARKAD'EV V.V., BOGDANOVA T.N., GUZHIKOV A.Y., LOBACHEVA S.V., MISHKYNA N.V., PLATONOV E.S., SAVEL'EVA Y.N., SHUREKOVA O.V., YANIN B.T., 2012 - Berriasian stage of the Mountainous Crimea. LEMA, St. Petersburg.

ARKAD'EV V., BARABOSHKIN E., BAGAEVA M.I., BOGDANOVA T.N., GUZHIKOV A.Y., MANIKIN A.G., PISKUNOV V.K., PLATONOV E.S., SAVEL'EVA Y.N., FEODOROVA A.A., SHUREKOVA O.V., 2015 - New data on Berriasian biostratigraphy, magnetostratigraphy and sedimentology in the Belogorsk area (Central Crimea). Stratigraphy and Geological Correlation, 23: 155-191.

BAKHMUTOV V.G., CASELLATO C.E., HALÁSOVÁ E., IVANOVA D. K., REHÁKOVÁ D., WIMBLEDON W.A.P., 2016 - Bio- and magnetostratigraphy of the Upper Tithonian-Lower Berriasian in southern Ukraine. 97-100. In: Proceedings Juras- 
sica Conference (Eds. M. Michalík, K. Fekete). Slovak Academy of Science.

BAKHMUTOV V.G., HALÁSOVÁ E., IVANOVA D.K., JÓZSA Š., REHÁKOVÁ D., WIMBLEDON W.A.P., 2018 - Biostratigraphy and magnetostratigraphy of the uppermost TithonianLower Berriasian in the Theodosia area of Crimea (southern Ukraine). Geological Quarterly, 62: 197-236.

BARABOSHKIN E.Y., GUZHIKOV A.Y., MANIKIN A.G., PIMENOV M.V., 2015 - Bio- and magnetostratigraphic data on the Jurassic-Cretaceous boundary of the Kashpir and Gorodishchi sections (Volga region, Russia): 25-31. In: The International Scientific Conference on the Jurassic/Cretaceous boundary. September 7-13, 2015, Samara (Russia)

BARRAGÁN R., LÓPEZ-MARTÍNEZ R., CHÁVEZ-VERGARA B., NÚÑEZ-USECHE F., SALGADO-GARRIDO H., MERINO A., 2020 - Geochemical variations across the Jurassic/Cretaceous boundary in central Mexico. Insights for correlation with Tethyan areas. Journal of South American Earth Sciences 99: DOI: 10.1016/j.jsames.2020.102521.

BAUDRIMONT A.F., DUBOIS P., 1977 - Un bassin mésogéen du domaine péri-alpin: le Sud-Est de la France. Bulletin des Centres de Recherches Exploration - Production Elf-Aquitaine, 1: 261-308.

BAUMGARTNER P.O., BARTOLINI A., CARTER E.S., CONTI M., CORTESE G., DANELIAN T., De WEVER P., DUMITRICA P., DUMITRICA-JU R., GORICAN S., GUEX J., HU D.M., KITOL N., MARCUCCI M., MATSUOKA A., MURCHEY A.B., O’DOGHERTY L., SAVARY J., VISHNEVSKAYA V., WIDZ D., YAO A., 1995 - Middle Jurassic to Early Cretaceous radiolarian biochronology of Tethys based on unitary associations. In: Middle Jurassic to Lower Cretaceous Radiolaria of Tethys: Occurrence, Systematics, Biochronology (Eds. P.O. Baumgartner et al.). Mémoires de Géologie, Lausanne, 23: 1013-1043.

BEAUDOIN B., 1970 - Sédimentation à "caractère flysh" dans une série carbonate "pélagique" (Jurassique terminal Crétacé basal des chaînes subalpines méridionales). Comptes-Rendus Sommaires de la Société géologique de France, 2: 58.

BEAUDOIN B., 1977 - Méthodes d'analyse sédimentaire et reconstitution du bassin: le Jurassique terminal - Berriasien des chaînes subalpines méridionales [Thèse Doctorat Université de Caen, France].

BEN ABDESSELAM-MAHDAOUI S., BENZAGGAGH M., BOUHLEL S., RAZGALLAH S., 2010 - Nouvelle données biostratigraphiques sur les niveaux de passage Jurassique-Crétacé et les calcaires du Campanien dans le secteur de Hammam Zriba-Jebel Guebli (Tunisie septentrionale). GeoEco-Trop, 34: $113-126$

BEN ABDESSELAM-MAHDAOUI S.B., BENZAGGAGH M., RAZGALLAH S., REBAH A., RAKIA B., 2011 - Les associations des calpionelles du Berriasien et du Valanginien inférieur de la Tunisie septentrionale. Comparaison avec les associations du Rif externe (Maroc). Comptes Rendus Paleovol, 10: 527535.

BENZAGGAGH M., CECCA F., SCHNYDER J., SEYED-EMAMI K., REZA MAJIDIFARD M., 2012 - Calpionelles et microfaunes pélagiques du Jurassique supérieur - Crétacé inféri- eur dans les Formations Shal et Kolur (Montagnes du Talesh, chaîne de l'Elbourz, Nord-Ouest Iran). Répartition stratigraphique, espèces nouvelles, revision systématique et comparaisons regionals. Annales de Paléontologie, 98: 253-301.

BENZAGGAGH M., HOMBERG C., SCHNYDER J., HSSAIDA T., 2015 - Intérêt des kystes de dinoflagellés calcaires et du biomicrofaciès pélagique dans la datation des terrains du sommet du Jurassique et de la base du Berriasien dans le domaine téthysien occidental. Annales de Paléontologie, 101: 251-263.

BOUGHDIRI M., SALLOUHI H., HADDAD S., CORDEY F., SOUSSI M., 2009 - Integrated biostratigraphy and regional correlations of Upper Jurassic-lowermost Cretaceous series in northern Tunisia. GFF, 131: 71-81.

BRAGIN V.Y., DZYUBA O.S., KAZANSKY A.Y., SHURYGIN B.N., 2013 - New data on the magnetostratigraphy of the Jurassic-Cretaceous boundary interval, Nordvik Peninsula (northern East Siberia). Russian Geology and Geophysics, 54: 335-348.

BULOT L.G., FRAU C., WIMBLEDON W.A.P., 2014 - New and poorly known Perisphinctoidea (Ammonitina) from the Upper Tithonian of Le Chouet (Drôme, SE France). Volumina Jurassica, 12: 113-128.

CASELLATO C.E., 2010 - Calcareous nannofossil biostratigraphy of Upper Callovian-Lower Berriasian successions from Southern Alps, North Italy. Rivista Italiana di Paleontologia e Stratigrafia, 116: 357-404.

CECCA F., SEYED-EMAMI K., SCHNYDER J., BENZAGGAGH M., REZA MAJIDIFARD M., MOHAMMADI MONFARED M., 2012 - Early Berriasian ammonites from Shal, Talesh region (NW Alborz Mountains, Iran). Cretaceous Research, 33: 106-115.

CELESTINO R., WOHLWEND S., REHÁKOVÁ D., WEISSERT H., 2017 - Carbon isotope stratigraphy, biostratigraphy and sedimentology of the Upper Jurassic-Lower Cretaceous Rayda Formation, Central Oman Mountains. Newsletters on Stratigraphy, 50: 91-109.

CHANNELL J.E.T., CASELLATO C.E., MUTTONI G., ERBA E., 2010 - Magnetostratigraphy, nannofossil stratigraphy and apparent polar wander for Adria-Africa in the Jurassic-Cretaceous boundary interval. Palaeogeography, Palaeoclimatology, Palaeoecology, 293: 51-75.

COLLOQUIUM, 1975 - Colloque sur la limite Jurassique-Crétacé, 1973, Lyon-Neuchatel, 1975. Bureau de Recherches Géologiques et Minières Memoires, 86: 1-393.

COURJAULT T., GROSHENY D., FERRY S., SAUSSE J., 2011 - Detailed anatomy of a deep-water carbonate breccia lobe (Upper Jurassic, French subalpine basin). Sedimentary Geology, 238: 156-171.

DEBRAND-PASSARD S., COURBOULEIX S., LIENHARDT M.-J., 1984 - Synthése géologique du Sud-Est de la France. Editions du Bureau de Récherches Géologiques et Minieres, 125: $1-615$.

DÉTRAZ H., MOJON P.O., 1989 - Evolution paléogéographique de la marge jurassienne de la Tethys du Tithonique-Portlandien au Valanginien: correlations biostratigraphique et séquentielle des faciès marins à continentaux. Eclogae Geologicae Helveticae, 82: 37-112. 
DZYUBA O.S., 2010 - Cylindroteuthid belemnite correlation of the Jurassic/Cretaceous boundary strata in Northern Siberia and Northern California. Earth Science Frontiers, 17: 79-80.

DZYUBA O.S., 2012 - Belemnites and biostratigraphy of the Jurassic-Cretaceous boundary deposits of northern east Siberia: new data on the Nordvik Peninsula. Stratigraphy and Geological Correlation, 20: 53-72.

DZYUBA O.S., 2013 - Belemnites in the Jurassic-Cretaceous boundary interval of the Mauryn'ya and Yatriya River Sections, Western Siberia: biostratigraphic significance and dynamics of taxonomic diversity. Stratigraphy and Geological Correlation, 21: 189-214.

DZYUBA O.S., IZOKH O.P., SHURYGIN B.N., 2013 - Carbon isotope excursions in Boreal Jurassic-Cretaceous boundary sections and their correlation potential. Palaeogeography, Palaeoclimatology, Palaeoecology, 381/382: 33-46.

DZYUBA O.S., URMAN O.S., SHURYGIN B.N., 2015 - Belemnites and bivalves from the Jurassic-Cretaceous boundary interval of the Kashpir section, Middle Volga Basin, Russia: Implications for biostratigraphy and panboreal correlation: 36-41. In: International Scientific Conference on the Jurassic/Cretaceous boundary. September 7-13, 2015, Samara. Togliatti.

ELBRA T., SCHNABL P., ČÍŽKOVÁ K., PRUNER P., KDÝR Š., GRABOWSKI J., REHÁKOVÁ D., SVOBODOVÁ A., FRAU C., WIMBLEDON W.A.P., 2018a - Palaeo- and rock magnetic investigations across Jurassic-Cretaceous boundary at St Bertrand's Spring, Drôme, France - Applications to magnetostratigraphy. Studia Geophysica et Geodaetica, 62: 323-338.

ELBRA T., BUBÍK M., REHAKOVÁ D., SCHNABL P., ČÍŽKOVÁ K., PRUNER P., KDÝR Š., SVOBODOVÁ A., ŠVÁBENICKÁ L., 2018b - Magneto- and biostratigraphy across the Jurassic-Cretaceous boundary in the Kurovice section, Western Carpathians, Czech Republic. Cretaceous Research, 89: 211223.

FISHER R., 1953 - Dispersion on a sphere. Proceedings of the Royal Society A, 217: 295-305.

FLÜGEL E., 2004 - Microfacies of Carbonate Rocks. SpringerVerlag, Berlin.

FLÜGEL E., 2010 - Microfacies of carbonate rocks. Analysis, Interpretation and Application (2nd ed.) Springer-Verlag, BerlinHeidelberg.

FÖZY.I., JANSSEN N.M.M., PRICE G.D., KNAUER J., PÁLFY J., 2010 - Integrated isotope and biostratigraphy of a Lower Cretaceous section from the Bakony Mountains (Transdanubian Range, Hungary): A new Tethyan record of the Weissert event. Cretaceous Research, 31: 525-545

FRAU C., BULOT B.G., WIMBLEDON W.A.P., 2015 - The Upper Tithonian Himalayitidae Spath, 1925 (Perisphinctoidea, Ammonitina) from Le Chouet (Drome, France): implications for the systematics. Geologica Carpathica, 66: 117-132.

FRAU C., BULOT B.G., REHÁKOVÁ D., WIMBLEDON W.A.P., 2016a - Revision of the ammonite index species Berriasella jacobi Mazenot, 1939 and its consequences for the biostratig raphy of the Berriasian Stage. Cretaceous Research, 66: 94114.

FRAU C., BULOT B.G., WIMBLEDON W.A.P., IFRIM C., 2016b - Systematic palaeontology of the Perisphinctoidea in the Jurassic/Creaceous boundary interval at Le Chouet (Drome,
France), and its implications for biostratigraphy. Acta Geologica Polonica, 66: 157-177.

FRAU C., BULOT B.G., WIMBLEDON W.A.P., IFRIM C., 2016c - Late Tithonian Himalayitidae Spath, 1925 and Neocomitidae Salfeld, 1921 (Perisphinctoidea, Ammonoidea) from Charens (Drôme, France). Geologica Carpathica, 67: 543-559.

FRAU C., WIMBLEDON W.A.P., IFRIM C., BULOT L.G., POHL A., 2020. Berriasian ammonites of supposed Tethyan origin from the type "Ryazanian", Central Russia: a systematic re-interpretation. Palaeoworld. Doi.org/10.1016/j.palwor.2020.07.004.

GALLOWAY J.G., VICKERS M., PRICE G.D., POULTON T.P., GRASBY S.E., HADLARI T., BEAUCHAMP B., SULPHUR K., 2019 - Finding the VOICE: organic carbon isotope chemostratigraphy of the Late Jurassic-Early Cretaceous of Arctic Canada. Geological Magazine. Doi: 10.1017/S0016756819001316.

GRABOWSKI J., 2010 - Magnetostratigraphy of the Jurassic/Cretaceous boundary interval in the Western Tethys and its correlations with other regions: a review. Volumina Jurassica, 9: 105128.

GRABOWSKI J., HAAS J., MARTON E., PSZCZÓŁKOWSKI A., 2010a - Magneto- and biostratigraphy of the Jurassic/Cretaceous boundary in the Lokút section (Transdanubian Range, Hungary). Studia Geophysica et Geodaetica, 54: 1-26.

GRABOWSKI J., MICHALÍK J., PSZCZÓŁKOWSKI A., LINTNEROVÁ O., 2010b - Magneto- and isotope stratigraphy around the Jurassic/Cretaceous boundary in the Vysoká Unit (Malé Karpaty Mts, Slovakia): correlations and tectonic implications. Geologica Carpathica, 61: 309-326.

GRABOWSKI J., LAKOVA I., SCHNABL P., SOBIEŃ K. PETROVA S., 2014 - Berriasian bio-and magnetostratigraphy and magnetic susceptibility of the Barlya section (Western Balkan Unit, Bulgaria) - preliminary results. Volumina Jurassica, 12: 185-194.

GRABOWSKI J., LAKOVA I., PETROVA S., STOYKOVA K., IVANOVA D., WOJCIK-TABOL P., SOBIEN' K., SCHNABL P., 2016 - Palaeomagnetism and integrated stratigraphy of the Upper Berriasian hemipelagic succession in the Barlya section, Western Balkan, Bulgaria: implications for lithogenic input and palaeoredox potential. Palaeogeography, Palaeoclimatology, Palaeoecology, 461: 156-177.

GRABOWSKI J., HAAS J., STOYKOVA K., WIERZBOWSKI H., BRAŃSKI P., 2017 - Environmental changes around the Jurassic/Cretaceous transition: new nannofossils, chemostratigraphic and stable isotope data from the Lók'ut section (Transdanubian Range, Hungary). Sedimentary Geology, 360: 54-72.

GRABOWSKI J., BAKHMUTOV V., KDYR S., KROBICKI M., PRUNER P., REHÁKOVÁ D., SCHNABL P., STOYKOVA K., WIERZBOWSKI H., 2019 - Integrated stratigraphy and palaeoenvironmental interpretation of the Upper Kimmeridgian to Lower Berriasian pelagic sequences of the Velykyi Kamianets section (Pieniny Klippen Belt, Ukraine). Palaeogeography, Palaeoclimatology, Palaeoecology, 532: DOI: 10.1016/j.palaeo.2019.05.038.

GRADSTEIN F.M., OGG J.G., SCHMITZ M., OGG G. (Eds.), 2012 - The geologic time scale, Elsevier.

GRANIER B., FERRY S., BENZAGGAGH M. 2020 - A critical look at Tré Maroua (Le Saix, Hautes-Alpes, France), the Berriasian GSSP candidate section. Carnets Geologie, 20: 1-17. 
GUZHIKOV A.Y., 2013 - Solving unsolvable problems in stratigraphy (Comments on the paper "New data on the magnetostratigraphy of the Jurassic-Cretaceous boundary interval, Nordvik Peninsula (northern east Siberia)" by Bragin et al.). Russian Geology and Geophysics, 54: 349-354.

GUZHIKOV A.Y., BARABOSHKIN E.Y., 2008 - New magnetostratigraphic data on boreal Neocomian of the Bojarka River key section (northern Siberia): 66-69. In: Cretaceous System of Russia and adjacent countries: problems of stratigrahy and palaeogeography. Proceedings of the Fourth All-Russian meeting Novosibirsk.

GUZHIKOV A.Y., ARKADIEV V.V., BARABOSHKIN E.Y., BAGAEVA M.I., PISKUNOV V.K., RUD'KO S.V., PERMINOV V.A., MANIKIN A.G., 2012 - New sedimentological, bio-, and magnetostratigraphic data on the Jurassic-Cretaceous boundary interval of Eastern Crimea (Feodosiya). Stratigraphy and Geological Correlation, 20: 261-294

GUZHIKOV A.Y., ARKADIEV V.V., BARABOSHKIN E.Y., FEODOROV, A.A., SHUREKOVA O.V., BARABOSHKIN E.E., MANIKIN A.G., GOLOZUBOV V.V., KASATKIN S.A., NECHAEV V.P., 2016 - New Bio- and magnetostratigraphic data at the Jurassic-Cretaceous boundary of the Chigan Cape (Vladivostok Region, Russia): 101-104. In: XXII Jurassica Conference Smolenice, Slovakia. Field Trip Guide and Abstracts Book. Slovak Academy of Sciences, Bratislava, 2016.

HAGGART J.W., MATSUKAWA M., 2019 - New belemnite records from the Mitarai Formation, Tetori Group, Japan: delimitation of the Jurassic-Cretaceous boundary in the Japanese Islands. Cretaceous Research, 111. doi: 10.1016/j.cretres.2019.104281.

HARDING I.C., SMITH G.A., RIDING J.B., WIMBLEDON W.A.P., 2011 - Inter-regional correlation of Jurassic/Cretaceous boundary strata based on the Tithonian-Valanginian dinoflagellate cyst biostratigraphy of the Volga Basin, western Russia. Review of Palaeobotany and Palynology, 147: 82-116.

HOEDEMAEKER P.J., JANNSEN N.M.M., CASELLATO C.E., GARDI S., REHÁKOVÁ D., JAMRICHOVA M., 2016 - Jurassic-Cretaceous boundary in the Río Argos succession (Caravaca, SE Spain). Revue de Paleobiogie, 35: 111-247.

HOUŠA V., KRS M., KRSOVÁ M., MAN O., PRUNER P., VENHODOVÁ D., 1999 - High-resolution magnetostratigraphy and micropaleontology across the Jurassic/Cretaceous boundary strata at Brodno near Žilina, western Slovakia: summary of results. Cretaceous Research, 20: 699-717.

HOUŠA V., KRS M., MAN O., PRUNER P., VENHODOVÁ D., CECCA F., NARD G., PISCITELLO M., 2004 - Combined magnetostratigraphic, palaeomagnetic and calpionellid investigations across Jurassic/Cretaceous boundary strata in the Bosso Valley, Umbria, Central Italy. Cretaceous Research, 25: 771-785.

IGLESIA LLANOS M.P.I., RAPALINI A.E., KIETZMANN D.A., VASQUEZ C.A., PALMA R., 2015 - Palaeomagnetism of the Jurassic-Cretaceous Vaca Muerta Formation, Neuquén basin, Argentina. Proceedings São Paulo, Brasil. Special Issue B16. Latinmag Letters, 6: 1-3.

IGLESIA LLANOS M.P.I., KIETZMANN D.A., MARTINEZ M.H., PALMA R.M., 2017 - Magnetostratigraphy of the Upper Jurassic-Lower Cretaceous from Argentina: implications for the $\mathrm{J}-\mathrm{K}$ boundary in the Neuquén Basin. Cretaceous Research, 70: 189-208.
IVANOVA D.K., KIETZMANN D.A., 2016 - Calcareous dinoflagellate cysts from the Tithonian - Valanginian Vaca Muerta Formation in the southern Mendoza area of the Neuquén Basin, Argentina. Conference abstract: 20. In: VI Simposio Argentino del Jurásico, Malargüe.

IVANOVA D.K., KIETZMANN D.A., 2017 - Calcareous dinoflagellate cysts from the Tithonian - Valanginian Vaca Muerta Formation in the southern Mendoza area of the Neuquén Basin, Argentina. Journal of South American Earth Sciences, 77: $150-169$.

JOSEPH P., BEAUDOIN B., SEMPÉRÉ T., MAILLART J., 1988 - Vallées sous-marines et systems d'épandages carbonatés du Berriasien vocontien (Alpes méridionales françaises). Bulletin de la Société Géologique de France, 8: 363-374.

KIETZMANN D.A., 2017 - Chitinoidellids from the Early Tithonian-Early Valanginian Vaca Muerta Formation in the Northern Neuquén Basin, Argentina. Journal of South American Earth Sciences, 76: 152-164.

KIETZMANN D.A., BLAU J., RICCARDI A.C., PALMA R.M., 2011 - An interesting finding of chitinoidellids (Calpionellidea Bonet) in the Jurassic-Cretaceous boundary of the Neuquén Basin: 1480-1481. In: $18^{\circ}$ Congreso Geológico Argentino, Actas CD: Neuquén.

KIETZMANN D.A., IGLESIA-LLANOS M.P., KOHAN MARTÍNEZ M., 2018a - Astronomical calibration of the Upper Jurassic-Lower Cretaceous in the Neuquén Basin, Argentina: a contribution from the Southern Hemisphere to the Geologic Time Scale. In: Stratigraphy \& Timescales 3 (Ed. M. Montenari), Elsevier.

KIETZMANN D., IGLESIA LLANOS M.P., IVANOVA D.K., KOHAN MARTINEZ M., STURLESI M.A., 2018b - Toward a multidisciplinary chronostratigraphic calibration for the Jurassic-Cretaceous transition in the Neuquén Nasin. Revista de la Asociación Geológica Argentina, 75: 175-187.

KIRSCHVINK J.L., 1980 - The least-squares line and plane and the analysis of palaeomagnetic data. Geophysical Journal of the Royal Astronomical Society, 62: 699-718.

KOŠŤÁK M., VAŇKOVÁ L., MAZUCH M., BUBÍK M., REHÁKOVÁ D., 2018 - Cephalopods, small vertebrate fauna and stable isotope $\left(\delta^{13} \mathrm{C}, \delta^{18} \mathrm{O}\right)$ record from the Jurassic-Cretaceous transition (uppermost Crassicollaria through Calpionella Zones) of the Outer Western Carpathians, Kurovice quarry (Czechia). Cretaceous Research, 92: 43-65.

KOWAL-KASPRZYK J., REHÁKOVÁ D., 2019 - A morphometric analysis of loricae of the genus Calpionella and its significance for the Jurassic/Cretaceous boundary interpretation. Newsletters on Stratigraphy, 52: 33-54.

KUZNETSOV A.B., IZOKH O.P., DZYUBA, O.S., SHURYGIN B.N., 2017 - Sr isotope composition in belemnites from the Jurassic-Cretaceous boundary section (Maurynya River, Western Siberia). Doklady Earth Sciences, 477: 1408-1413.

LAKOVA I., PETROVA S., 2013 - Towards a standard Tithonian to Valanginian calpionellid zonation of the Tethyan Realm. Acta Geologica Polonica, 63: 201-221.

LAKOVA I, PETROVA S., ANDREEVA P.V., MELODIEV L., REHÁKOVÁ D., MICHALIK J., 2017 - Notes on the stratigraphy and microfacies of Tithonian and Berriasian carbonate 
sequence around Dragovishtitsa Village (Western Srednogorie, Bulgaria). Comptes rendus de l'Académie bulgare des sciences: sciences mathématiques et naturelles, 70: 1429-1436

Le HÉGARAT G., 1973 - Le Berriasien du sud-est de la France. Université Claude Bernard, Lyon, Thése, 149: 1-576.

LENA L., LÓPEZ-MARTÍNEZ R., LESCANO M., AGUIRE-URRETA B., CONCHEYRO A., VENNARI V., NAIPAUER M., SAMANKASSOU E., PIMENTEL M., RAMOS V.A., SCHALTEGGER U., 2019 - High-precision U-Pb ages in the early Tithonian to early Berriasian and implications for the numerical age of the Jurassic-Cretaceous boundary. Solid Earth, 10: $1-14$.

LÓPEZ-MARTINEZ R., BARRAGAN R., REHAKOVA D., 2013a - Calpionellid distribution and microfacies across the Jurassic/Cretaceous boundary in western Cuba (Sierra Los Organos). Geologica Carpathica, 64: 195-208.

LÓPEZ-MARTÍNEZ R., BARRAGÁN R., REHÁKOVÁ D., $2013 \mathrm{~b}$ - The Jurassic/Cretaceous boundary in the Apulco area by means of calpionellids and calcareous dinoflagellates: an alternative to the classical Mazatepec section in eastern Mexico. Journal of South American Earth Sciences, 47: 142-151.

LÓPEZ-MARTÍNEZ R., BARRAGÁN R., REHÁKOVÁ D., COBIELLA-REGUERA J.L., 2013c - Reply to the comment of A. Pszczółkowski on "Calpionellid distribution and microfacies across the Jurassic/Cretaceous boundary in western Cuba (Sierra de los Organos)" by Lopez-Martinez et al. Geologica Carpathica, 64: 499-501.

LÓPEZ-MARTÍNEZ R., BARRAGÁN R., REHÁKOVÁ D., MARTINI M., EGUILEZ de ANTUNANO S., 2015a - Calpionellid biostratigraphy, U-Pb geochronology and microfacies of the Upper Jurassic-Lower Cretaceous Pimienta Formation (Tamazunchale, San Luis Potosi, central-eastern Mexico). Boletin de la Sociedad Geologica Mexicana, 67: 75-86.

LÓPEZ-MARTÍNEZ R., BARRAGÁN R., REHÁKOVÁ D., 2015 b - Calpionellid biostratigraphy across the Jurassic/Cretaceous boundary in San José de Iturbide, Nuevo León, north eastern Mexico. Geological Quarterly, 59: 581-592

LÓPEZ-MARTÍNEZ R., AGUIRRE-URRETA B., LESCANO M., CONCHEYRO A., VENNARI V., RAMOS V.A., 2017 - Tethyan calpionellids in the Neuquén Basin (Argentine Andes), their significance in defining the Jurassic/Cretaceous boundary and pathways for Tethyan-Eastern Pacific connections. Journal of South American Earth Sciences, 78: 1-10.

LUKENEDER A., HALÁSOVÁ E., KROH A., MAYRHOFER S., PRUNER P., REHÁKOVÁ D., SCHNABL P., SPROVIERI M., WAGREICH M., 2010 - High resolution stratigraphy of the Jurassic-Cretaceous boundary interval in the Gresten Klippen Belt (Austria). Geologica Carpathica, 61: 365-381.

MICHALÍK J., REHÁKOVÁ D., 2011 - Possible markers of the Jurassic/Cretaceous boundary in the Mediterranean Tethys A review and state of art. Geoscience Frontiers, 2: 475-490.

MICHALÍK J., REHÁKOVÁ D., HALÁSOVÁ E., LINTNEROVÁ O., 2009 - The Brodno section - a potential regional stratotype of the Jurassic/Cretaceous boundary (Western Carpathians). Geologica Carpathica, 60: 213-232.

MICHALÍK J., REHÁKOVÁ D., GRABOWSKI J., LINTNEROVÁ O., SVOBODOVÁ A., SCHLÖGL J., SOBIEŃ K., SCHNABL P., 2016 - Stratigraphy, lithological and magnetic proxies of the Jurassic/Cretaceous boundary interval in the Pieniny Klippen Belt (Western Carpathians Slovakia). Geologica Carpathica, 67: 303-328.

NØHR-HANSEN H., PIASECKI S., ALSEN P., 2019 - A Cretaceous dinoflagellate cyst zonation for NE Greenland. Geological Magazine. doi.org/10.1017/ S0016756819001043.

OGG J.G., LOWRIE W., 1986 - Magnetostratigraphy of the Jurassic/Cretaceous boundary. Geology, 14: 547-550.

PESSAGNO E.A., CANTU CHAPA A., MATTINSON J.M., MENG X., KARIMIA S.M., 2009 - The Jurassic-Cretaceous boundary: new data from North America and the Caribbean. Stratigraphy, 6: 185-262.

PESTCHEVITSKAYA E., LEBEDEVA N., RYABOKON A., 2011 - Uppermost Jurassic and lowermost Cretaceous dinocyst successions of Siberia, the Subarctic Urals and Russian Platform and their interregional correlation. Geologica Carpathica, 62: 189-202.

PETROVA S., RABRENOVIĆ D., LAKOVA I., KOLEVA-REKALOVA E., IVANOVA D., METODIEV L., MALEŠEVIĆ N., 2012 - Biostratigraphy and microfacies of the pelagic carbonates across the Jurassic/Cretaceous boundary in eastern Serbia (Stara Planina-Poreč Zone). Geologica Balcanica, 41: 53-76.

PETROVA S., KOLEVA-REKALOVA E., IVANOVA D., LAKOVA I., 2019 - Biostratigraphy and microfacies of the pelagic carbonate formations in the Yavorets section (Tithonian-Berriasian), Western Balkan Mts, Bulgaria. Geologica Balcanica, 48: 51-73.

PLATONOV E., LAKOVA I., PETROVA S., ARKADIEV V., 2014 - Tithonian and Lower Berriasian calpionellid against ammonite biostratigraphy of the Dvuyakornaya Formation in eastern Crimea. Geologica Balcanica, 43: 63-76.

POP G., 1974 - Les zones des Calpionelles Tithonique-Valang iniens du silon de Reșița (Carpathes Méridionales). Revue Roumaine de Géologie Géophysique et Géographie, Série Géologie, 18: 109-125.

POP G., 1994 - Calpionellid evolutive events and their use in biostratigraphy. Romanian Journal of Stratigraphy, 76: 7-24.

PRICE G.D., FÖZY, I., PÁLFY J., 2016 - Carbon cycle history through the Jurassic-Cretaceous boundary: A new global $\delta^{13} \mathrm{C}$ stack. Palaeogeography, Palaeoclimatology, Palaeoecology, 451: 46-61.

PRUNER P., HOUŠA V., OLORIZ F., KOŠŤÁK M., KRS M., MAN O., SCHNABL P., VENHODOV D., TAVERA J.M., MAZUCH M., 2010 - High-resolution magnetostratigraphy and biostratigraphic zonation of the Jurassic/Cretaceous boundary strata in the Puerto Escano section (southern Spain). Cretaceous Research, 31: 192-206.

PSZCZÓŁKOWSKI A., 2009 - The Tithonian-earliest Berriasian Nannoconus zones in selected sections of the Pieniny Klippen Belt and the Western Tatra Mountains (southern Poland). Studia Geologica Polonica, 132: 7-38.

PSZCZÓŁKOWSKI A., 2013 - Comment on "Calpionellid distribution and microfacies across the Jurassic/Cretaceous boundary in western Cuba (Sierra de los Órganos)" by López-Martínez et al. Geologica Carpathica, 64: 497-498.

PSZCZÓŁKOWSKI A., 2016 - The Tithonian Chitinoidellidae and other microfossils from Owadów-Brzezinki quarry (central Poland). Volumina Jurassica, 14: 133-144. 
REBOULET S., SZIVES O., AGUIRRE-URRETA B., BARRAGAN R., COMPANY M., 2018 - Report on the 6th International Meeting of the IUGS Lower Cretaceous Ammonite Working Group, the Kilian Group (Vienna, Austria, 20th August 2017). Cretaceous Research, 91: 100-110.

REHÁKOVÁ D., 2000a - Evolution and distribution of the Late Jurassic and Early Cretaceous calcareous dinoflagellates recorded in the Western Carpathian pelagic carbonate facies. Mineralia Slovaca, 32: 79-88.

REHÁKOVÁ D., 2000b - Calcareous dinoflagellates and calpionellid bioevents versus sea-level fluctuations recorded in the West Carpathians (Late Jurassic/Early Cretaceous pelagic environments). Geologica Carpathica, 51: 229-243.

REHÁKOVA D., ROZIC B., 2019 - Calpionellid biostratigraphy and sedimentation of the Biancone limestone from the Rudnica Anticline (Sava Folds, eastern Slovenia). Geologija, 62: 89101.

REHÁKOVÁ D., HALÁSOVÁ E., LUKENEDER A., 2009 - The Jurassic-Cretaceous boundary in the Gresten Klippenbelt (Nutzhof, Lower Austria): Implications for Micro- and Nannofacies analysis. Annalen des Naturhistorischen Museums in Wien, 110 A: 345-381.

REHÁKOVÁ D., MATYJA, B., WIERZBOWSKI A., SCHLÖGL J., KROBICKI M., BARSKI M., 2011 - Stratigraphy and microfacies of the Jurassic and lowermost Cretaceous of the Veliky Kamenets section (Pieniny Klippen Belt, Carpathians, Western Ukraine). Volumina Jurassica, 9: 61-104.

REMANE J., 1964 - Untersuchungen zur Systematik und Stratigraphie der Calpionellen in den Jura-Kreide-Grenzschichten des Vocontischen Troges. Palaeontographia A, 123: 1-57.

REMANE J., 1986 - Calpionellids and the Jurassic-Cretaceous boundary. Acta Geologica Hungarica, 29: 15-26.

REMANE J., BASSETT M.G., COWIE J.C., GOHRBANDT K.H., LANE H.R., MICHELSEN O., WANG N., 1996 - Revised guidelines for the establishment of global chronostratigraphic standards by the International Commission on Stratigraphy (ICS). Episodes, 19: 77-81.

RICCARDI A.C., 2015 - Remarks on the Tithonian-Berriasian ammonite biostratigraphy of west central Argentina. Volumina Jurassica, 13: 23-52.

ROGOV M.A., 2010 - New data on ammonites and stratigraphy of the Volgian stage in Spitzbergen. Stratigraphy and Geological Correlation, 18: 505-531.

ROGOV M., ZAKHAROV V., 2009 - Ammonite- and bivalvebased biostratigraphy and Panboreal correlation of the Volgian Stage. Science in China Series D, Earth Sciences, 52: 18901909.

ROGOV M.A., ALIFIROV A.S., IGOLNIKOV A.E., 2015 - Revised ammonite succession of the Upper Volgian of Nordvik section: zonal boundaries and uncertainties: 70-76. In: The International Scientific Conference on the Jurassic/Cretaceous boundary. September 7-13, 2015, Samara.

SALLOUHI H., BOUGHDIRI M., CORDEY F., 2011 - Tithonian Chitinoidellids of the South-Tethyan Margin of the Maghreb: New data from northern Tunisia. Comptes Rendus Palevol, 10: 641-653.

SANO S.-I., IBA Y., SHINJI I., ASAI H., DZYUBA O.S., 2015 Preliminary report of earliest Cretaceous belemnites from Ja- pan and their palaeogeographic significance. Journal of the Geological Society of Japan, 125: 71-79.

SATOLLI S., TURTU A., 2016 - Early Cretaceous magnetostratigraphy of the Salto del Cieco section (Northern Apennines, Italy). Newsletters on Stratigraphy, 49: 361-382.

SATOLLI S., TURTU A., DONATELLI U., 2015 - Detailed magnetostratigraphy of the Salto del Cieco section (Northern Apennines, Italy) from the Pliensbachian to Jurassic/Cretaceous boundary. Newsletters on Stratigraphy, 48: 153-177.

SCHNABL P., PRUNER P., WIMBLEDON W.A.P., 2015 - A review of magnetostratigraphic results from the Tithonian-Berriasian of Nordvik (Siberia) and possible biostratigraphic constraints. Geologica Carpathica, 66: 489-498.

SCHNABL P., LI G., KDÝR Š., KLETETSCHKA G., SKUPIEN P., SVOBODOVA A., HLADIKOVA K., CAO M., WIMBLEDON W.A.P., 2019 - Comparison of the palaeomagnetic parameters of non-marine Jurassic-Cretaceous boundary sediments in Dorset (SW England), Hebei and Liaoning (NE China) a preliminary study. Open Journal of Geology, 9: 654-657.

SHURYGIN B., DZYUBA O.S., 2015 - The Jurassic/Cretaceous boundary in northern Siberia and Boreal-Tethyan correlation of the boundary beds. Russian Geology and Geophysics, 56: 652662 .

STOYKOVA K., IDAKIEVA V., IVANOV M., REHÁKOVÁ D., 2018 - Calcareous nannofossil and ammonite integrated biostratigraphy across the Jurassic-Cretaceous boundary strata of the Kopanitsa composite section (West Srednogorie Unit, southwest Bulgaria). Geologica Carpathica, 69: 199-217.

SVOBODOVA A., KOŠŤÁK M., 2016 - Calcareous nannofossils of the Jurassic-Cretaceous boundary strata in the Puerto Escaño section (southern Spain) - biostratigraphy and palaeoecology. Geologica Carpathica, 67: 223-238.

SVOBODOVÁ A., ŠVÁBENICKÁ L., REHÁKOVÁ D., SVOBODOVÁ M., SKUPIEN P., ELBRA T., SCHNABL P., 2019 - The Jurassic/Cretaceous boundary and high resolution biostratigraphy of the pelagic sequences of the Kurovice section (Outer Western Carpathians, the northern Tethyan margin). Geologica Carpathica, 70: 153-182.

URMAN O.S., DZYUBA O.S., KIRILLOVA G.L., SHURYGIN B.N., 2014 - Buchia Faunas and Biostratigraphy of the Jurassic-Cretaceous Boundary Deposits in the Komsomolsk Section (Russian Far East). Russian Journal of Pacific Geology, 8: 346-359.

VAŇKOVÁ L., ELBRA T., PRUNER P., VAŠÍČEK, Z., SKUPIEN P., REHÁKOVÁ D., SCHNABL P., KOŠŤÁK M., ŠVÁBENICKÁ L., SVOBODOVÁ A., BUBÍK M., MAZUCH M., ČÍŽKOVÁ K., KDÝR Š., 2019 - Integrated stratigraphy and palaeoenvironment of the Berriasian peri-reefal limestones at Štramberk (Outer Western Carpathians, Czech Republic). Palaeogeography, Palaeoclimatology, Palaeoecology 532: 109256. Doi: https://doi.org/10.1016/j.palaeo.2019.109256.

VAŠÍČEK Z., REHAKOVA D., SKUPIEN P., 2017 - Some perisphinctoid ammonites of the Stramberk Limestone and their dating with associated microfossils (Tithonian to Lower Berriasian, Outer Western Carpathians, Czech Republic). Geologica Carpathica, 68: 583-605

VENNARI V.V., ÁlVAREZ P.P., AGUIRRE-URRETA B., 2012 A new species of Andiceras Krantz (Cephalopoda: Ammono- 
idea) from the Late Jurassic-Early Cretaceous of the Neuquén Basin, Mendoza, Argentina. Systematics and biostratigraphy. Andean Geology, 39: 92-105.

VENNARI V.V., LESCANO M., NAIPAUER M., AGUIRRE-URRETA B., CONCHEYRO A., SCHALTEGGER U., ARMSTRONG R., PIMENTEL M., RAMOS V.A., 2014 - New constraints in the Jurassic-Cretaceous boundary in the High Andes using high-precision U-Pb data. Gondwana Research, 26: $374-385$.

WEISSERT H., CHANNELL J.E.T., 1989 - Tethyan carbonate carbon isotope stratigraphy across the Jurassic-Cretaceous boundary: An indicator of decelerated global carbon cycling? Palaeoceanography, 4: 483-494.

WIMBLEDON W.A.P., 2008 - The Jurassic-Cretaceous boundary: an age-old correlative enigma. Episodes, 31: 423-428.

WIMBLEDON W.A.P., 2014 - Warsaw remarks - Berriasian progress. Volumina Jurassica, 12: 107-112.

WIMBLEDON W.A.P., 2017 - Developments with fixing a Tithonian/Berriasian (J/K) boundary. Volumina Jurassica, 15: 107112.

WIMBLEDON W.A.P., CASELLATO C.E., REHÁKOVÁ D., BULO L.G., ERBA E., GARDIN S., VERREUSSEL R.M.C.H., MUNSTERMAN D.K., HUNT C.O., 2011 - Fixing a basal Berriasian and Jurassic/Cretaceous $(\mathrm{J} / \mathrm{K})$ boundary - is there perhaps some light at the end of the tunnel? Rivista Italiana di Paleontologia e Stratigrafia, 117: 295-307.

WIMBLEDON W.A.P., REHÁKOVÁ D., PSZCZÓŁKOWSKI A., CASELLATO C.E., HALÁSOVÁ E., FRAU C., BULOT L.G., GRABOWSKI J., SOBIEŃ K., PRUNER P., SCHNABL P., ČÍŽKOVÁ K., 2013 - A preliminary account of the bio- and magnetostratigraphy of the upper Tithonian - lower Berriasian interval at Le Chouet, Drôme (SE France). Geologica Carpathica, 64: 437-460.

WIMBLEDON W.A.P., MOHIALDEEN I.M.J., ANDREINI G., REHÁKOVÁ D., STOYKOVA, K., 2016 - Jurassic/Cretaceous boundary beds in Kurdistan - a preliminary note on wider correlations: 269-276. In: Special Issue - GeoKurdistan II. Journal of Zankoy Sulaimani Part A.

WIMBLEDON W.A.P., REHÁKOVÁ D., HALÁSOVÁ E., LINTNEROVA I., MICHALÍK J., PRUNER, P., SCHNABL P., ČÍŽKOVÁ K., KOŠŤÁK M., SVOBODOVÁ A., BULO L.G., FRAU C., BAKHMUTOV V., GRABOWSKI J., WIERZBOWSKI A., PSZCZÓŁKOWSKI A., LEANZA H., RICCARDI A., VENNARI V., AGUIRRE-URETTA B., TCHOUMATCHENKO P., STOYKOVA K., IVANOVA D., SHA J,
LI G., CAO M., LI J., WAN X., RIDING J., HUNT C.O., RAWSON P., COPESTAKE P., ARNAUD VANNEAU A.M., MOHIALDEEN I.J., ANDREINI G., PARISI G., SPERANZA F., SATOLLI S., LOPEZ-MARTINEZ R., BARRAGAN R., BENZAGGAGH M., VERREUSSEL R.M.C.H., MUNSTERMAN D.K., HOEDEMAEKER P., VAJDA V., ERBA E., CASELLATO C.E., BOWN P., PANDEY K., FÖZY I., BARDHAN S., MOJON P.-O., SAMES B., LAKOVA I., IVANOV M., POULTON T.P., GALLOWAY J., HAGGART J.W., DAVIES E.H., ALSEN P., PIACECKI S., GARDIN S., GALBRUN B., OGG J., LUCAS-CLARK J., PUJANA I., KHAND Y., OLORIZ F., 2017 - The Tithonian/Berriasian stage boundary and the base of the Cretaceous System: 290 In: 10th Int. Symposium on the Cretaceous, 2017, Vienna. Berichte der Geologischen Bundesanstalt Band 120.

WIMBLEDON W.A.P., REHÁKOVÁ D., SVOBODOVÁ A., SCHNABL P., PRUNER P., ELBRA T., ČÍŽKOVÁ K., KDÝR Š., FRAU C., SCHNYDER J., GALBRUN B., 2020a - Fixing a J/K boundary: a comparative account of key Tithonian-Berriasian profiles in the departments of Drôme and Hautes-Alpes, France. Geologica Carpathica, 71: 24-46

WIMBLEDON W.A.P., REHÁKOVÁ D., SVOBODOVÁ A., ELBRA T., SCHNABL P., PRUNER P., ŠIFNEROVÁ K., KDÝR Š., DZYUBA O., SCHNYDER J., GALBRUN B., KOŠŤÁK M., VAŇKOVÁ L., COPESTAKE P., HUNT C.O., RICCARDI A., POULTON T.P., BULOT J.G., FRAU C., DE LENA L., 2020b - The proposal of a GSSP for the Berriasian Stage (Cretaceous System): Part 1. Volumina Jurassica, 18: 53-106.

WOHLWEND S., CELESTINO R., REHÁKOVÁ D., HUCK S., WEISSERT H., 2016 - Late Jurassic to Cretaceous evolution of the eastern Tethyan Hawasina Basin (Oman Mountains). Sedimentology, 64: 87-110.

ZÁK K., KOŠŤÁK M., MAN O., ZAKHAROV V.A., ROGOV M.A., PRUNER P., DZYUBA O.S., ROHOVEC J., MAZUCH M., 2011 - Comparison of carbonate $\mathrm{C}$ and $\mathrm{O}$ stable isotope records across the Jurassic/Cretaceous boundary in the Boreal and Tethyan Realms. Palaeogeography, Palaeoclimatology, Palaeoecology, 299: 83-96.

ZAKHAROV V.A., ROGOV M.A., DZYUBA O.S., ŽÁK K., KOŠŤÁK M., PRUNER P., SKUPIEN P., CHADIMA M., MAZUCH M., NIKITENKO B.L., 2014 - Palaeoenvironments and palaeoceanography changes across the Jurassic/Cretaceous boundary in the Arctic realm: case study of the Nordvik section (north Siberia, Russia). Polar Research, 33: 19714, http://dx.doi.org/10.3402/polar.v33.19714. 
Appendix 1

\section{MICROFACIES DETAILS AT TRÉ MAROUA}

\begin{tabular}{|c|c|c|c|}
\hline M & Sample no. & Lithology & Microfacies \\
\hline \multicolumn{4}{|c|}{ Lower section, left bank } \\
\hline 13.58 & TL28 & micrite, mudstone (matrix) & \\
\hline 13.00 & TL27m & biomicrite, wackestone & radiolarian-calpionellid \\
\hline 12.70 & TL26 & biomicrite, wackestone & radiolarian-calpionellid \\
\hline 12.42 & TL251 & biomicrite, wackestone & radiolarian-calpionellid \\
\hline 12.27 & TL23t & biomicrite, wackestone & calpionellid \\
\hline 11.90 & TL23m & biomicrite, wackestone & calpionellid-radiolarian \\
\hline 11.15 & TL22 & biomicrite, wackestone, slight bioturbation & calpionellid-radiolarian \\
\hline 10.50 & TL21 & biomicrite, wackestone/mudstone, slight bioturbation & calpionellid-globochaete \\
\hline 10.27 & TL201 & biomicrite, wackestone & calpionellid-globochaete \\
\hline 10.07 & TL19 & biomicrite, wackestone & radiolarian.-calpionellid-globochaete \\
\hline \multirow{2}{*}{10.00} & \multirow{2}{*}{ TL18 } & \multirow{2}{*}{ biomicrite, wackestone } & calpionellid-globochaete \\
\hline & & & radiolarian.-calpionellid-globochaete \\
\hline 9.30 & TL171 & biomicrite, wackestone & calpionellid-radiolarian \\
\hline 9.18 & TL17 & biomicrite, wackestone & calpionellid-globochaete \\
\hline 8.88 & TL16(-20) & biomicrite & calpionellid-radiolarian \\
\hline 8.55 & TL16 & biomicrite, wackestone, slight bioturbation & calpionellid-radiolarian \\
\hline 8.40 & TL14(-10) & biomicrite, wackestone & calpionellid-globochaete \\
\hline \multirow{2}{*}{8.27} & \multirow{2}{*}{ TL14 } & biomicrite, wackestone, one clast & calpionellid-globochaete \\
\hline & & biomicrite, wackestone & radiolarian-calpionellid \\
\hline 8.18 & TL13t & biomicrite, wackestone & calpionellid-globochaete \\
\hline 7.95 & TL13(-20) & biomicrite, wackestone & calpionellid-globochaete \\
\hline 7.90 & TL13m & biomicrite, wackestone & calpionellid-globochaete \\
\hline 7.52 & TL131 & biomicrite, wackestone & calpionellid-globochaete \\
\hline 7.40 & TL12t & biomicrite, wackestone & calpionellid-globochaete \\
\hline 6.65 & TL12(-80) & biomicrite, wackestone & calpionellid-globochaete \\
\hline 6.47 & TL12m & biomicrite, wackestone slight bioturbation & calpionellid-globochaete \\
\hline 6.22 & TL12 & biomicrite, wackestone & calpionellid-globochaete \\
\hline 5.50 & TL121 & biomicrite, wackestone & calpionellid-globochaete \\
\hline 4.63 & TL1 (-40) & biomicrite + lithoclasts, slight bioturbation & calpionellid-radiolarian \\
\hline 4.25 & TL11b & biomicrite, wackestone & calpionellid-globochaete \\
\hline 3.95 & TL10m & biomicrite, wackestone & saccocoma-calpionellid-globochaete \\
\hline 3.63 & TL10 & micrite, mudstone & calpionellid-globochaete \\
\hline 3.32 & TL9 & biomicrite, wackestone & saccocoma-radiolarian \\
\hline 3.05 & TL8 & lithoclasts + bioclasts & calpionellid-globochaete \\
\hline 2.30 & TL8b & biomicrite, wackestone & saccocoma-globochaete \\
\hline 2.20 & TL7 & biomicrite, wackestone, bioturbation, rare bioclasts. & saccocoma-globochaete \\
\hline 2.13 & TL6 & biomicrite, wackestone & saccocoma-globochaete \\
\hline 2.15 & TL5 & biomicrite, wackestone & saccocoma-globochaete \\
\hline 2.05 & TL4 & biomicrite, wackestone & saccocoma-globochaete \\
\hline 1.85 & TL3t & biomicrite, wackestone & saccocoma-globochaete \\
\hline 1.53 & TL2t & biomicrite, wackestone & saccocoma-globochaete \\
\hline 1.35 & TL2(-25) & biomicrite, wackestone & saccocoma-globochaete \\
\hline 1.30 & TL2m & biomicrite, wackestone & saccocoma-globochaete \\
\hline 1.05 & TL2(+5) & biomicrite, wackestone & saccocoma-globochaete \\
\hline
\end{tabular}




\begin{tabular}{|l|l|l|l|}
\hline M & Sample no. & \multicolumn{1}{|c|}{ Lithology } & \multicolumn{1}{|c|}{ Might bank section } \\
\hline \multicolumn{3}{|l|}{} & \multicolumn{1}{|c|}{ radiolarian-calpionellid-globochaete } \\
\hline 3.05 & Fs 14 & biomicrite, wackestone slightly burrowed & radiolarian-calpionellid-globochaete \\
\hline 2.95 & Fs 13 & biomicrite, wackestone & \\
\hline 2.92 & Fs 12' & biomicrite, wackestone passing to breccia & calpionellid-globochaete \\
\hline 2.88 & Fs 12 & biomicrite, wackestone, burrowed & calpionellid-globochaete \\
\hline 2.65 & Fs 11 & biomicrite, wackestone, burrowed & calpionellid-globochaete \\
\hline 2.48 & Fs 10 & biomicrite, wackestone, burrowed & calpionellid-globochaete \\
\hline 2.37 & Fs 9 & biomicrite, wackestone & calpionellid-globochaete \\
\hline 2.27 & Fs 8 & biomicrite, wackestone & calpionellid-globochaete \\
\hline 2.10 & Fs 7 & biomicrite, wackestone, burrowed & calpionellid-globochaete \\
\hline 1.62 & Fs 6 & biomicrite, wackestone & calpionellid-globochaete \\
\hline 1.20 & Fs 5 & biomicrite, wackestone & calpionellid-globochaete \\
\hline 1.10 & Fs 4b & biomicrite, wackestone, slightly laminated & calpionellid-globochaete \\
\hline 0.95 & Fs 4a & biomicrite, wackestone & \\
\hline 0.70 & Fs 3 & breccia, intra- and extraclasts - matrix biomicrite wackestone & \\
\hline 0.35 & Fs 2 & breccia, intra- and extraclasts - matrix biomicrite wackestone & calpionellid-globochaete \\
\hline 0.25 & Fs 1 & biomicrite, wackestone, burrowed & saccocoma-calpionellid-globochaete \\
\hline 0.02 & Fs 0 & biomicrite, wackestone & \\
\hline
\end{tabular}




\section{STATUS OF THIS PROPOSAL}

After more than ten years of work the Berriasian WG completed its discussions and arrived at what was considered to be the best possible proposal for the Berriasian GSSP. The work has demanded important effort, time and financial input from the WG members, with considerable diversion from their everyday aims, functions and duties.

The informed specialists of the WG overwhelmingly voted, firstly to choose a primary marker (by $75 \%$ ) and then to choose a GSSP (by 73\%). These decisions were based on sound correlations, founded on documentation of many sites and their fossil, magnetic and other characters. The derived data for the GSSP compares well and in some cases are even superior to those used to define other ratified Cretaceous GSSP's.

The approved proposal was first submitted to the Cretaceous Subcommission on 1st December 2019, and during the following six weeks the WG received some negative comments produced by three members of the Subcommission. On that basis the proposal was reviewed and most observations and criticisms were answered with a direct written reply and/or by inserting explanations and improvements into the original text. Regrettably, the WG never got back any comment on its detailed revision. The revised proposal covered all the limitations and positives for correlation in the $\mathrm{J} / \mathrm{K}$ interval and all that is correlatively possible and useful was described, and what is less possible was discussed, even at some length. Its conclusions have already been cited (Gradstein et al., 2020).

Finally, in September 2020 the reviewed proposal was resubmitted and was the subject of a vote by the Cretaceous Subcommission. Of the twenty-two persons in the Subcommission, eight (32\%) voted against the proposal, eight voted "Yes", four did not vote, and two abstained. When the Subcommission Chairperson was asked for the concrete reasons that justified the negative votes the only reply was that "the voting members of the Subcommission are free to express their opinions and provide explanations if they are willing to do so". Clearly, an unexpected answer within a scientific organization like ICS/ IUGS.

Although, as here explained, this proposal has not been approved and its final status remains open, the authors continue with research on the site and with publication of Part 2, as it contains a wealth of information that could be useful for future research.

GRADSTEIN F.M., OGG J.G., SCHMITZ M.D., OGG G.M. (Eds.), 2020 - Geologic time scale. Elsevier. 